\title{
Non-Ionic Surfactants for Stabilization of Polymeric Nanoparticles for Biomedical Uses
}

\author{
Hernán Cortés ${ }^{1,+}+\mathbb{D}$, Héctor Hernández-Parra ${ }^{2,+}$, Sergio A. Bernal-Chávez ${ }^{3}$, María L. Del Prado-Audelo $4{ }^{\mathbb{D}}$, \\ Isaac H. Caballero-Florán ${ }^{2,3}$, Fabiola V. Borbolla-Jiménez ${ }^{1}$, Maykel González-Torres ${ }^{5}$ (D) Jonathan J. Magaña ${ }^{1,4, * \mathbb{D}}$ \\ and Gerardo Leyva-Gómez ${ }^{3, * \text { (D) }}$
}

1 Laboratorio de Medicina Genómica, Departamento de Genómica, Instituto Nacional de Rehabilitación Luis Guillermo Ibarra Ibarra, Ciudad de México 14389, Mexico; hcortes@inr.gob.mx (H.C.); fvbj@hotmail.com (F.V.B.-J.)

2 Departamento de Farmacología, Centro de Investigación y de Estudios Avanzados del Instituto Politécnico Nacional, Ciudad de México 07360, Mexico; hector.hernandez@cinvestav.mx (H.H.-P.); hiram.qfohead@gmail.com (I.H.C.-F.)

3 Departamento de Farmacia, Facultad de Química, Universidad Nacional Autónoma de México, Ciudad de México 04510, Mexico; q901108@hotmail.com

4 Escuela de Ingeniería y Ciencias, Departamento de Bioingeniería, Tecnológico de Monterrey Campus Ciudad de México, CDMX, Ciudad de México 14380, Mexico; luisa.delpradoa@gmail.com

5 CONACyT-Laboratorio de Biotecnología, Instituto Nacional de Rehabilitación Luis Guillermo Ibarra Ibarra, Ciudad de México 14389, Mexico; mikegcu@gmail.com

check for updates

Citation: Cortés, H.;

Hernández-Parra, H.; Bernal-Chávez, S.A.; Prado-Audelo, M.L.D.; Caballero-Florán, I.H.;

Borbolla-Jiménez, F.V.;

González-Torres, M.; Magaña, J.J.;

Leyva-Gómez, G. Non-Ionic

Surfactants for Stabilization of

Polymeric Nanoparticles for

Biomedical Uses. Materials 2021, 14,

3197. https://doi.org/10.3390/

ma14123197

Academic Editor: Pedro Fonte

Received: 10 May 2021

Accepted: 31 May 2021

Published: 10 June 2021

Publisher's Note: MDPI stays neutral with regard to jurisdictional claims in published maps and institutional affiliations.

Copyright: (c) 2021 by the authors. Licensee MDPI, Basel, Switzerland. This article is an open access article distributed under the terms and conditions of the Creative Commons Attribution (CC BY) license (https:/ / creativecommons.org/licenses/by/ $4.0 /)$.
* Correspondence: magana.jj@tec.mx (J.J.M.); leyva@quimica.unam.mx (G.L.-G.)

+ These authors contributed equally to this work.

\begin{abstract}
Surfactants are essential in the manufacture of polymeric nanoparticles by emulsion formation methods and to preserve the stability of carriers in liquid media. The deposition of nonionic surfactants at the interface allows a considerable reduction of the globule of the emulsion with high biocompatibility and the possibility of oscillating the final sizes in a wide nanometric range. Therefore, this review presents an analysis of the three principal non-ionic surfactants utilized in the manufacture of polymeric nanoparticles; polysorbates, poly(vinyl alcohol), and poloxamers. We included a section on general properties and uses and a comprehensive compilation of formulations with each principal non-ionic surfactant. Then, we highlight a section on the interaction of non-ionic surfactants with biological barriers to emphasize that the function of surfactants is not limited to stabilizing the dispersion of nanoparticles and has a broad impact on pharmacokinetics. Finally, the last section corresponds to a recommendation in the experimental approach for choosing a surfactant applying the systematic methodology of Quality by Design.
\end{abstract}

Keywords: non-ionic surfactant; nanoparticle; polysorbates; poly(vinyl alcohol); poloxamer; stability; quality by design

\section{Introduction}

Surface active agents, commonly known as "surfactants", are molecules that decrease surface and interfacial tension at the interfaces between solids, liquids, and gases, acting as dispersants, wetting agents, emulsifiers, and detergents [1]. Furthermore, surfactants can maintain the stability of the dispersed phases through the primary interaction at the interface, regulating the exchange of energy and matter in natural and synthetic processes. Thus, the participation of surfactants in the interaction of apparently incompatible phases is crucial [2].

A dispersed system consists of one substance distributed (dispersed phase) in discrete units in a second substance (continuous phase). Most of the nanoparticle manufacturing methods in the biomedical field involve forming a liquid/liquid stable dispersed system with the contribution of surfactant agents to produce a new colloidal type solid/liquid 
dispersed system. The initial globule size of emulsified dispersed systems is greater than the colloidal particle size at the end of the manufacturing process, combined with the presence of a high surface free energy and, therefore, the tendency of resulted nanoparticles (NP) to flocculate and coagulate can be observed [3]. At the same time, the stability of NP as a dispersed system in an aqueous medium is a fundamental challenge and a critical subject of argumentation in most studies [4]. For this reason, the presence of surfactants is essential before, during, and after the formation of the NP [5].

The presence of a surfactant affects the particle size, polydispersity index (PDI), drug loading, zeta potential value, and correlation with apparent physical stability [6]. For this reason, traditionally, the focus of surfactants is restricted to the stability phenomena of NP [7]. However, the biological interaction highly depends on the surface phenomena of the NP and, consequently, on surfactant agents [8]. The arrangement of surfactants at biological interfaces contributes to cell, tissue, and organ homeostasis. Currently, it highlights the trend of surfactant therapies to lessen alterations in surface tension derived from inflammatory processes. However, the levels of industrial surfactants in the environment have always been a matter of concern and monitoring [9-11]. Current applications of surfactants in the manufacture of NP for biomedical applications seek a vectorization phenomenon to facilitate drug release at receptor sites [12]. In this regard, the participation of surfactants represents a multifunctional ingredient that usually requires adsorption by covalent crosslinking to guarantee better performance in biological pathways $[13,14]$.

Polymeric NP are carriers that predominate in biomedical applications, while nonionic surfactants confer high biocompatibility in most methodologies. For several decades, most nanoparticle formulations have included one of the following three excipients as a surfactant: polysorbates (PS), poly(vinyl alcohol) (PVA), or poloxamers. This broad trajectory of study has allowed an abundant exploration of technological benefits and formulation limitations.

This work is a tribute to the principal non-ionic surfactants utilized to manufacture polymeric NP in the biomedical field. It focuses on the three leading excipients for stabilization: PS, PVA, and poloxamers. The purpose of this work is to offer an overview of each type of non-ionic surfactant, including a general description of the types of molecules in the family, general applications, obtention of derivatives in search of novel properties, and formulation of NP with tables that condense aspects of the physicochemical parameters of the NP according to the type of stabilizer. Moreover, we mention a brief section on toxicity aspects, a critical section on advantages and disadvantages, and a section on drawbacks and future. Finally, this review presents an analysis of the influence of surfactants on the interaction with biological barriers and a narrative and comprehensive description of the main variables involved in the methodological selection of surfactants through the Quality by Design strategy (QbD).

\section{Use of Surfactants for Nanoparticle Stabilization}

Surfactants are crucial excipients in the synthesis of NP; they are amphiphilic molecules characterized by a hydrophilic head group (ionic or non-ionic) and a hydrophobic tail (Figure 1a). The amphiphilic nature of surfactants has been exploited to stabilize hydrophobic nanomaterials in aqueous media [15]. Hydrophobic regions interact with NP surfaces, and hydrophilic regions interact with water (Figure 1b), thus providing colloidal stability and improving dispersion stability by preventing NP aggregation $[15,16]$. The therapeutic potential of polymeric NP generally depends on their physicochemical properties such as size, shape, zeta potential, loading capacity, and surface functionalization with suitable surfactants $[17,18]$.

\subsection{Background}

Soap (general formula RCO-ONa) is formulated from anionic surfactants, and the first records of its manufacture date back to 2800 B.C. in ancient Babylon $[19,20]$. However, the word "surfactant" was first used in the 1940s [3,17]. More recently, in the 1960s, the 
term "amphiphilic" was introduced by Paul Winsor, a word that comes from two Greek roots (Amphi meaning "double", and Philos meaning "affinity") [3]. Finally, between the 1950s and 1970s, the first models based on n-alkylammonium were developed to study the arrangement and orientation of cationic surfactants in solid interfaces; these explain the position and approximate inclination angle of adsorbed surfactant molecules and their physicochemical implications in the surface coating $[17,21]$. As a result, the surfactants industry has increased due to its wide application and discoveries. A field in which the utility of surfactants is currently exploited is the pharmaceutical industry since scientists have developed polymeric NP to administer therapeutic and diagnostic agents [22].

\section{a) Surfactant structure}

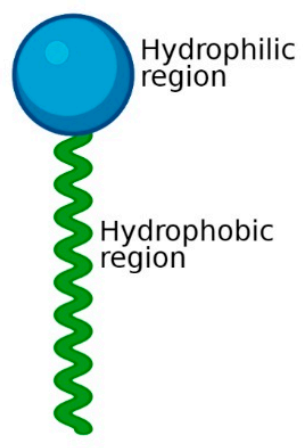

b) Nanoparticle coating

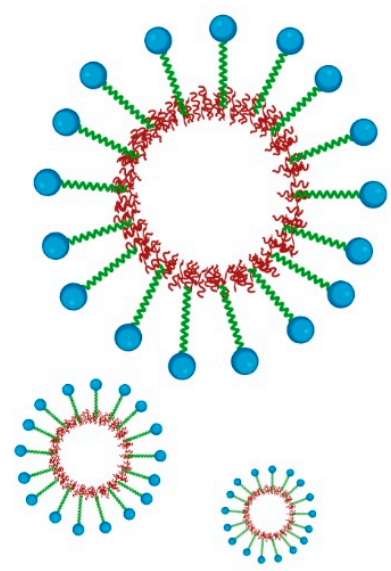

c) Classification of surfactants

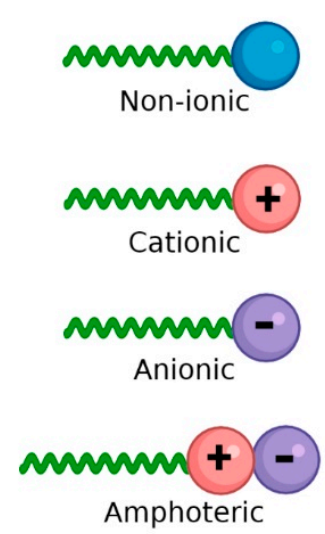

Figure 1. Surfactants for nanoparticle stabilization. (a) Classic structure of surfactants: its amphiphilic nature is represented with a hydrophilic region and a hydrophobic region. (b) Coating of NP with surfactants: the hydrophobic region possesses an affinity for the nanoparticle surface and the hydrophilic region with an affinity for the aqueous dispersion medium. (c) Classification of surfactants according to the ionic charge in its polar group: no charge (non-ionic), positive charge (cationic), negative charge (anionic), and both positive and negative charge (amphoteric).

\subsection{Stabilization Mechanisms}

The physical stability of NP mainly depends on electrostatic, steric, entropic, and Van der Waals forces [23]. The DLVO theory (Derjaguin-Landau-Verwey-Overbeek) describes the interaction energy between particles as the sum of electrostatic and Van der Waals forces; the resulting equilibrium explains the stability (suspension or flocculation) of colloidal systems [24]. When the surface charge of NP is homogeneous (either positive or negative), the Van der Waals and electrostatic forces oppose each other, causing the net force between particles to be strongly repulsive, and a stable suspension is formed [24,25]. As NP get closer to each other, their ionic atmospheres begin to overlap, and a repulsive force develops. On the other hand, Van der Waals interactions between NP are also generated due to forces between individual molecules in each colloid [26].

More stable dispersions can be obtained when the system contains oppositely charged $\mathrm{NP}$ and surfactants, such as anionic NP and cationic surfactants or vice versa. The dominant mechanisms are electrostatic interactions and hydrogen bonding [27]. In electrostatic stabilization, a minimum zeta potential of $|20 \mathrm{mV}|$ has been suggested [28]. However, there have been reported cases in which nanosuspensions with zeta potential below $|20 \mathrm{mV}|$ are physically stable $[29,30]$. This could be explained by the addition of non-ionic surfactants and the resulting steric effect. Therefore, the interpretation of the zeta potential to predict the stability of colloidal nanosuspensions should be considered with caution and in conjunction with the surfactants utilized [29]. 


\subsection{Ionic and Non-Ionic Surfactants}

Surfactants are classified according to the charge of their main group (polar head): non-ionic (uncharged) and ionic (charged) (Figure 1c). Among those that are charged, we find anionic (negatively charged), cationic (positively charged), and amphoteric (both positively and negatively charged) [31]. The charges of the zwitterionic or amphoteric surfactants can be permanent or can depend on the $\mathrm{pH}$ value to which they are exposed; for example, betaines can function as cationic surfactants at highly acidic $\mathrm{pH}$ [32,33]. A study showed the sensitivity of sulfobetaine to alteration of $\mathrm{pH}$ and inorganic salt. Hydrogen bonds are formed between the amide groups of 3-( $N$-erucamidopropyl- $N, N$-dimethyl ammonium) propane sulfonate and coordinated water in trans- $\left[\mathrm{FeCl}_{2}\left(\mathrm{H}_{2} \mathrm{O}\right)_{4}\right] \mathrm{Cl}$ structure; this masks the ionic forces of repulsion between the head groups of surfactants [34]. The zwitterionic head groups of phosphatidylcholine show electroneutral charges and high hydration, making them highly stable in aqueous media [35]. In addition, their electrostatic attraction causes the polarity of ionic surfactants to the dipoles of water. Moreover, non-ionic surfactants are solubilized without ionizing through the effect of weak hydrophilic groups such as ether-type bonds and hydroxyl groups; these are employed more frequently in pharmaceutical products. In Table 1, examples of surfactants commonly used in pharmaceutical formulations are mentioned.

Table 1. Examples of surfactants used in pharmaceutical formulations.

\begin{tabular}{|c|c|c|}
\hline Type & Surfactants & References \\
\hline Anionic & $\begin{array}{l}\text { Carboxylates (alkyl carboxylates-fatty acid salts). } \\
\text { Sulfates (sodium lauryl sulfate, alkyl ether sulfates). } \\
\text { Sulfonates (dioctyl sodium sulfosuccinate, alkyl } \\
\text { benzene-sulfonates). } \\
\text { Phosphate esters (alkyl aryl ether phosphates, alkyl } \\
\text { ether phosphates). }\end{array}$ & {$[1,36]$} \\
\hline Cationic & $\begin{array}{l}\text { Quaternary ammonium (cetrimonium bromide, } \\
\text { cetylpyridinium chloride, } \\
\text { dimethyldioctadecylammonium chloride). } \\
\text { Amine-Based (triethylamine hydrochloride, } \\
\text { octenidine dihydrochloride). } \\
\text { Pyridinium surfactants (benzethonium chloride) }\end{array}$ & {$[32,37]$} \\
\hline Non-ionic & $\begin{array}{l}\text { Polyol esters (fatty acid esters of sorbitan). } \\
\text { Polyoxyethylene esters (polysorbates). } \\
\text { Poloxamers (poloxamer 188). }\end{array}$ & {$[1,36]$} \\
\hline Amphoteric & $\begin{array}{l}\text { Phospholipids (phosphatidylcholine or lecithin). } \\
\text { Carboxylic Acid/Quaternary Ammonium } \\
\text { (cocamidopropyl betaine or amidosulfobetaine-16). } \\
\text { Phosphoric Acid/Quaternary Ammonium } \\
\text { (hexadecyl phosphocholine). } \\
\text { Betaines (alkylamidopropyl betaine). }\end{array}$ & {$[32,36,38]$} \\
\hline
\end{tabular}

\subsection{New Surfactants}

A wide range of classic surfactant agents is based on alkyl, peptides, lipids, DNA, molecular ligands, and polymers [17]. In recent years, particular interest has been placed in developing new biocompatible surfactant agents, representing low toxicity for the environment and human use; some of these agents are mentioned below. Carbohydrates: Have been studied due to their biodegradability and low toxicity profile. Smulek et al. [39] investigated a series of alkyl glycosides containing d-lixose and 1-rhamnose with alkyl chains of 8-12 carbon atoms. The results revealed that long-chain alkyl glycosides could be inexpensive biocompatible surfactants. Alkylpolyglucosides: Include a group of non-ionic surfactants with excellent wetting, dispersing, and surface tension reducing properties; their use for the stabilization of lipid NP is more frequent than classical stabilizers [40]. ImS3-n (3-(1-alkyl-3-imidazolium) propane-sulfonate): Represent a versatile class of zwitte- 
rionic compounds, which form normal and inverse micelles, capable of stabilizing NP in water and organic media [41]. Polyhydroxy Surfactants: Involve ethylene oxide-free nonionic stabilizers known for their dermatological properties and favorable environmental profile [42]. Rhamnolipids: Biosurfactants produced by marine bacteria have shown a lack of cytotoxicity and mutagenicity, which justifies their commercial exploitation as natural and ecological biosurfactants $[43,44]$. Animal-derived surfactants: in the same context of using biocompatible surfactants, bioglycolipids such as cerebrosides (which represent a group of non-ionic surfactants) and gangliosides (these are good cationic surfactants) have been proposed [45]. PEG-ylated amides: PEG-conjugated amides improve the stability of nanosystems and allow a prolonged circulation time, reducing the phenomenon of accelerated blood clearance $[46,47]$. Recently, BioNTech and Pfizer used two novel surfactants in the formulation of their BNT162b2 mRNA Covid-19 vaccine, the PEG-ylated lipid ALC0159 (2-[(polyethylene glycol)-2000]- $N, N$-ditetradecylacetamide) and the cationic lipid ALC-0315 ((4-hydroxybutyl)azanediyl)bis(hexane-6,1-diyl)bis(2-hexyldecanoate)) [48,49]. ALC-0159 allows forming a hydrophilic layer that sterically stabilizes the nanosystem, contributing to storage stability and reducing non-specific binding to proteins. Furthermore, ALC-0315 forms an electrostatic interaction with the negatively charged RNA skeleton allowing its stabilization, encapsulation, and the formation of particles [48,50]. Notably, several already known surfactants have been associated with new biological activities such as ceramides. For example, exogenously administered N-hexanoyl-D-erythrosphingosine has been reported to arrest the cell cycle, and in combination with Paclitaxel in biodegradable polymeric NPs can significantly enhance apoptosis in multidrug-resistant and sensitive cells [51]. Other strategies include stabilizing solid micro- or NP (Pickering stabilization), surfactant-free, and confers high resistance to coalescence, making it attractive for pharmaceutical applications, where some surfactants can cause adverse effects [52,53]. In addition, organic and inorganic particles are used, utilizing steric and/or electrostatic repulsion to inhibit coalescence and improve emulsion stability. A recent study reported Pickering emulsions stabilized by biodegradable poly(lactic-co-glycolic acid) (PLGA) NP and exposed that the degree of stabilization is highly dependent on the polymer composition [54].

\section{Polysorbates}

PS are one of the most utilized stabilizers in the industry. Their physicochemical properties have a striking impact on nanoparticulate systems. Despite its broad applications, new PS properties and modes of employment are still being found and reported nowadays.

\subsection{Physicochemical Properties}

Tween is the commercial name for a group of compounds based on PS. PS are amphiphilic molecules synthesized by the reaction between sorbitan fatty acid ester with ethylene oxide. The PS chemical structure has a sorbitan head group where the hydroxyl groups are bound to a polyethylene glycol (PEG) chain. Basically, in the PS structure, the fatty acid side chain (hydrophobic fragment) is esterified with one of the PEG (hydrophilic fragment) side chains. However, the length of the PEG chains, the esterification in one or more hydroxyl groups in the side chain, changes in the head group, and the fatty acid composition are the fingerprint of each type of PS [55,56].

The HLB of PS (between 9.6-16.7) combined with their low critical micelle concentration (CMC) gives the PS high surface activity, even at low concentrations. Therefore, PS confer high stability to the NP during storage in an aqueous medium and freeze-drying or freeze/thaw processes. In addition, the use of PS prevents interface-induced aggregation and surface adsorption in particulate systems. Therefore, a PS concentration of 0.001 to $0.1 \%$ $(w / v)$ is commonly utilized in the biopharmaceutical area with suitable performance. PS are degraded through enzymes and chemically by autoxidation or hydrolysis pathways. The susceptibility to the oxidation process in PS resides in the PEG ester bonds and unsaturated alkyl chains. On the other hand, the chemical PS hydrolysis is catalyzed in acid or basic conditions and directly affects the free fatty acids and the unesterified sorbitan [33-35]. 


\subsection{Types}

The commercial PS present more complex interactions between their molecules. In addition, the extensive subproducts and isomers formed during the synthesis process can affect the stability and chemical activity. The group of PS accepted for the formulation in human products comprises the PS-20, PS-60, PS-65, and PS-80. However, in cosmetics, the PS-21, PS-40, PS-61, PS-81, and PS-85 are also used. All the PS are hydrophilic emulsifying and stabilizing agents. The distinct levels of lipophilicity and hydrophilicity among the PS arise from the chemical structural differences. The PS-20 presents the lauric acid as the main fatty acid, making it a more hydrophilic molecule than the PS-60 and PS-80, which present larger fatty acids: stearic acid and oleic acid, respectively. Likewise, PS-65 has stearic acid as the primary fatty acid; however, PS-65 possesses three esterified hydroxyl groups with stearic acid, which confer more lipophilicity (Figure 2) [55-57].

A)

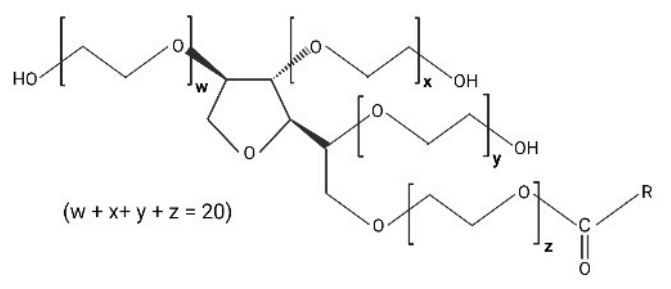

B)

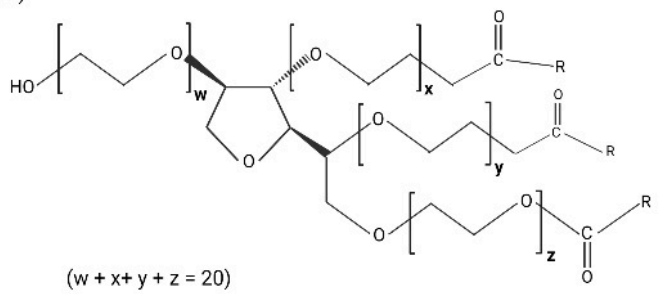

\begin{tabular}{|c|c|}
\hline Type of Polysorbate & Group (RCO-) \\
\hline PS-20 & $\mathrm{C}_{12} \mathrm{H}_{24} \mathrm{O}_{2}$ Lauric acid \\
\hline PS-60 & $\mathrm{C}_{18} \mathrm{H}_{36} \mathrm{O}_{2}$ Stearic acid \\
\hline PS-80 & $\mathrm{C}_{18} \mathrm{H}_{34} \mathrm{O}_{2}$ Oleic acid \\
\hline PS-65 & $\left(\mathrm{C}_{18} \mathrm{H}_{36} \mathrm{O}_{2}\right)_{3}$ Stearic acid \\
\hline
\end{tabular}

Figure 2. (A) Chemical structure of PS-20, PS-60, and PS-80. (B) Chemical structure of PS-65. PS-65 presents RCO-groups in $x, y$, and $z$, making it a tristearate molecule. The average of the total number of oxyethylene subunits on each polysorbate molecule $(w+x+y+z)$ is 20 .

\subsection{Uses}

PS are widely employed in the food, cosmetic, and pharmaceutical industries. Their roles include oil/water emulsifier, detergent, dispersing agent, solubilizer, and stabilizer in cosmetics. PS are common ingredients in applications for skin, hair, nails, and mucous membranes, with a typical application several times a day depending on the product. With a medical approach, the PS-20 and PS-80 are listed as clarifying agents in ophthalmic products and as cleaning, wetting, or solvent agents for contact lenses in concentrations below $1.0 \%$ [58,59]. Nowadays, PS offer a wide application in the development of nanoparticulate systems to improve drug physicochemical properties, bioavailability, and therapeutic enhancement (Table 2). 
Table 2. Representative polymeric NP stabilized with polysorbates.

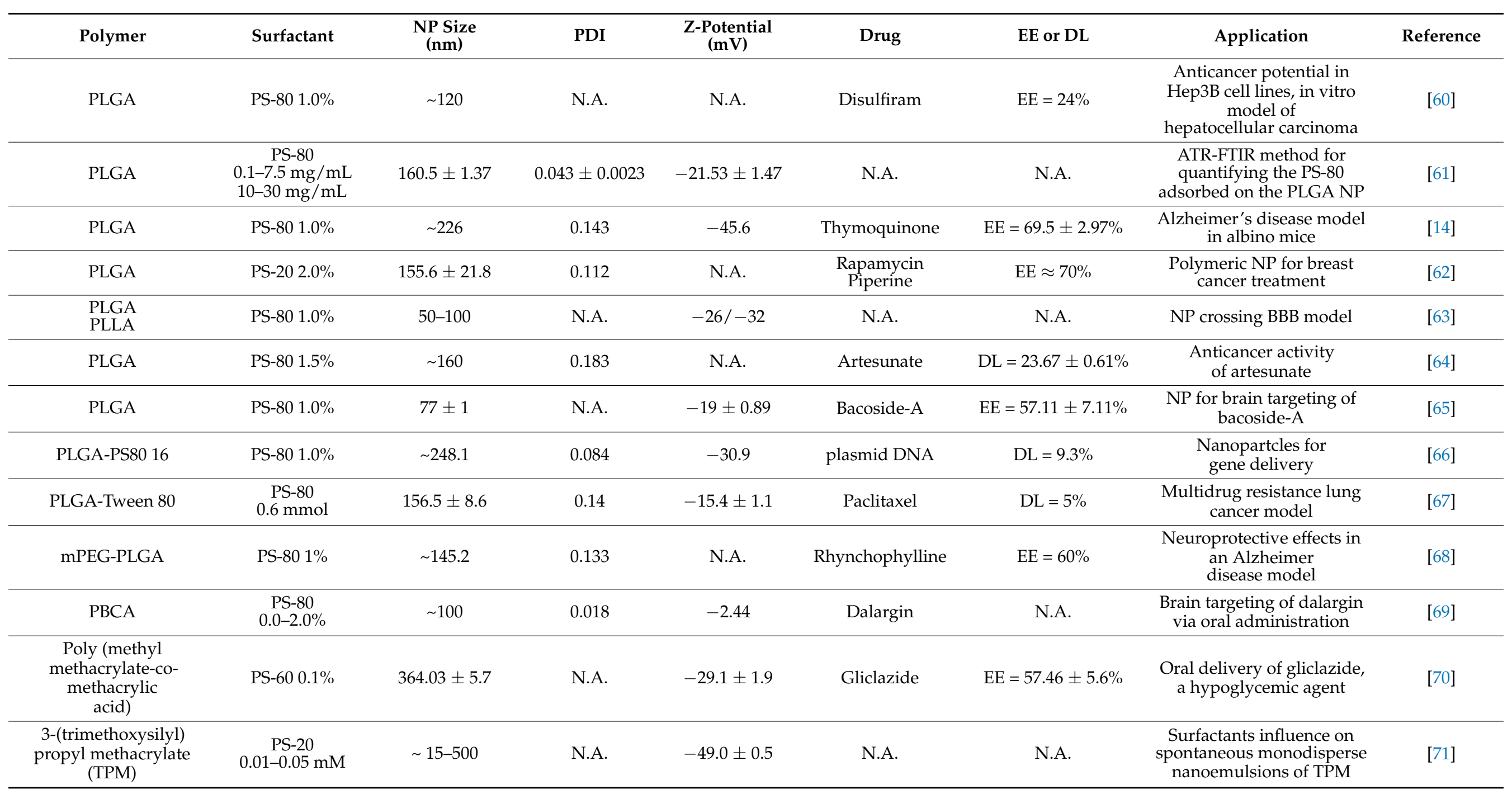


Table 2. Cont.

\begin{tabular}{|c|c|c|c|c|c|c|c|c|}
\hline Polymer & Surfactant & $\underset{(\mathrm{nm})}{\text { NP Size }}$ & PDI & $\begin{array}{l}\text { Z-Potential } \\
(\mathrm{mV})\end{array}$ & Drug & EE or DL & Application & Reference \\
\hline Polycaprolactone & PS-80 & 193 & 0.15 & -26.5 & Memantine & $\mathrm{EE}=80 \pm 3 \%$ & $\begin{array}{l}\text { Alzheimer's disease } \\
\text { approach }\end{array}$ & [72] \\
\hline Polycaprolactone & $\begin{array}{c}\text { PS-80 } \\
200 \text { and } 25 \\
(\mathrm{mg} / \mathrm{mL})\end{array}$ & $181-407$ & $0.3-0.5$ & $\begin{array}{l}+11.60 \text { to } \\
+29.20\end{array}$ & $\begin{array}{c}\text { Rosmarinus } \\
\text { officinalis and } \\
\text { Zataria multiflora } \\
\text { essential oils }\end{array}$ & $\mathrm{EE}=75.8-84.4 \%$ & $\begin{array}{l}\text { Entrapment of two } \\
\text { essential oils against } \\
\text { Tribolium confusum }\end{array}$ & [73] \\
\hline Polycaprolactone & $\begin{array}{c}\text { PS-80 } \\
2.65 \mathrm{mg} / \mathrm{mL} \\
5.3 \mathrm{mg} / \mathrm{mL} \\
10.6 \mathrm{mg} / \mathrm{mL} \\
21.2 \mathrm{mg} / \mathrm{mL}\end{array}$ & $\sim 200$ & N.A. & -6.73 & N.A. & N.A. & $\begin{array}{c}\text { Optimization of } \\
\text { nanoprecipitation method }\end{array}$ & [74] \\
\hline Polycaprolactone & $\begin{array}{l}\text { PS-80 } \\
0.5 \%\end{array}$ & $\begin{array}{c}\sim 170 \text { (uncoated) } \\
\sim 260-360 \\
\text { (chitosan coated) }\end{array}$ & $\begin{array}{c}0.181 \\
\text { (uncoated) } \\
0.345 \text { (chitosan } \\
\text { coated) }\end{array}$ & $\begin{array}{l}-12.91 \\
\text { (uncoated) } \\
+31.73 \\
\text { (chitosan } \\
\text { coated) }\end{array}$ & Paliperidone & $\mathrm{EE} \approx 60 \%$ & $\begin{array}{l}\text { Influence of PCL/drug } \\
\text { ratio, stabilizer type, and } \\
\text { high molecular weight of } \\
\text { chitosan coating }\end{array}$ & [75] \\
\hline Polystyrene & PS-20 0.1\% & $20-200$ & N.A. & N.A. & N.A. & N.A. & $\begin{array}{c}\text { NP distribution after } \\
\text { periocular administration }\end{array}$ & [76] \\
\hline $\begin{array}{l}\text { Polyhydroxybutyrate } \\
\text { (PHB) }\end{array}$ & PS-80 1\% v/v & $146 \pm 30$ & N.A. & -26 & Carvacrol & $\mathrm{DL}=12.5 \%$ & $\begin{array}{c}\text { Preparation and } \\
\text { characterization of PHB NP } \\
\text { by nanoprecipitation and } \\
\text { dialysis methods }\end{array}$ & [78] \\
\hline $\begin{array}{c}\text { Chitosan-folate } \\
\text { conjugated }\end{array}$ & PS-80 0.5\% v/v & $111.8 \pm 4.11$ & $0.50 \pm 0.21$ & N.A. & $\begin{array}{l}\text { Doxorubicin and } \\
\text { curcumin analog }\end{array}$ & N.A. & $\begin{array}{l}\text { Concentration of PS- } 80 \\
\text { decreased the size of NP }\end{array}$ & [79] \\
\hline $\begin{array}{l}\text { Chitosan and } \\
\text { chondroitin sulfate }\end{array}$ & PS-80 $15 \mathrm{mg}$ & $\sim 234$ & 0.2 & +30.0 & Artemether & $\mathrm{EE}=83 \pm 0.28 \%$ & $\begin{array}{c}\text { Transdermal antimalarial } \\
\text { drug delivery system }\end{array}$ & [80] \\
\hline Chitosan & PS-80 1.25\% & $208 \pm 0.01$ & N.A. & $-32.56 \pm 0.03$ & Imatinib & $\mathrm{EE}=68.52 \pm 0.01 \%$ & $\begin{array}{l}\text { Colorectal cancer } \\
\text { targeting application }\end{array}$ & [81] \\
\hline Sodium Alginate & PS-80 & $\sim 383$ & 0.2 & 200 & Curcumin & $\mathrm{EE}=95 \%$ & $\begin{array}{l}\text { Bioavailability in healthy } \\
\text { human volunteers }\end{array}$ & {$[82]$} \\
\hline
\end{tabular}

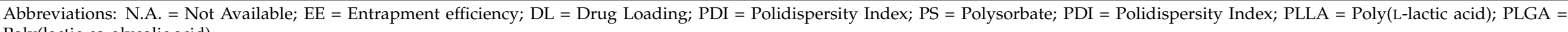
Poly(lactic-co-glycolic acid). 


\subsection{Derivatives}

PS are mainly utilized to refine the physicochemical properties of nanoparticle systems. With this scope, the synthesis of new derivatives of PS has also been investigated. For example, Masotti and coworkers [83] synthesized three PS-20 derivatives, differenced each other by substituted head groups. The PS-20 was functionalized with glycine, $\mathrm{N}$-methylglycine, or $\mathrm{N}, \mathrm{N}$-dimethyl-glycine to develop a $\mathrm{pH}$-sensitive system. PS-20 derivatives were obtained by reaction of the PS with different amino substituents in the presence of $\mathrm{H}_{2} \mathrm{SO}_{4}$ at $90{ }^{\circ} \mathrm{C}$ for $12 \mathrm{~h}$. The three derivatives exhibited the capacity to form vesicles complex with cholesterol molecules-the vesicles presented a size between 176 and $320 \mathrm{~nm}$, in a $\mathrm{pH}$ range of 5.5 to 7.4. The three types of vesicle size increased while the $\mathrm{pH}$ decreased. In contrast, the $\mathrm{Z}$ potential decreased to more negative values while the $\mathrm{pH}$ increased. These changes confirm the $\mathrm{pH}$-sensitive effect of the vesicles prepared with the modified PS and open the opportunity to develop new systems with $\mathrm{pH}$ response activity.

Similarly, other groups have modified polymers using PS to improve some functions in nanoparticle systems. These molecules are not accurately derivatives of PS, but the addition of PS improved cellular uptake, even in multidrug-resistant cancer cells [66,67]. Evidence of this is the PLGA-PS-80 copolymer NP developed by Yuan et al. [67]. The authors synthesized by esterification reaction $0.3 \mathrm{mmol}$ of PLGA-COOH with $0.6 \mathrm{mmol}$ of PS-80. The novel copolymer was employed to obtain NP by the nanoprecipitation technique. The particles presented a size of $156.5 \pm 8.6 \mathrm{~nm}$, a PDI of 0.14 , and a zeta potential of $-15.4 \pm 1.1 \mathrm{mV}$. PLGA-PS-80 NP were able to load $5 \%$ of $1 \mathrm{mg}$ paclitaxel. PLGA-PS-80 NP increased the cellular uptake in lung cancer cell line A549/T, with a higher level of cytotoxicity than unmodified PLGA NP. Furthermore, the nanoparticle system was evaluated in vivo and exhibited a higher antitumor efficacy than free taxol. The development of new derivatives and copolymers of PS opens the opportunity to improve existing drugs and their applications.

\subsection{Examples of NP Applications}

The PS-20 and PS-80 are mostly applied in biopharmaceutics to stabilize polymeric $\mathrm{NP}$, and both have a suitable preventing protein adsorption and low toxicity profile $[55,56]$ (Table 2). However, the PS-80 presents a longer monounsaturated chain, making them more surface-active with a lower CMC. This property renders the PS-80 the most utilized PS for nanoparticle systems. Moreover, PS-80 is reported as a molecule with the functionality to enhance the crossing of NP through biological barriers. For example, the Poly(n-butyl cyanoacrylate) (PBCA) NP coated with PS-80 improved the dalargin-induced analgesia. Furthermore, PBCA NP summited to double PS- 80 coating could cross the gastrointestinal barrier after oral administration $[69,84]$. Similarly, the presence of the PS80 on the nanoparticle surface improves the crossing of the blood-brain barrier (BBB). The PS chemical properties interact with plasma protein such as apolipoprotein E. Receptors for the apolipoprotein expressed in the cells of the BBB promote receptor-mediated endocytosis; in consequence, the NP treated with PS-80 enhance the chance of the drug to reach the brain $[85,86]$.

Interestingly, the PS can be employed alone to form micellar systems to carry drugs. For example, Ravichandran et al. [87] developed a PS-80 nanomicellar system to transport piperlongumine and indocyanine green for cancer treatment. The system improved the drugs' storage stability, increased the photothermal conversion and cellular uptake of indocyanine green. In addition, the pro-oxidant activity of the piperlongumine was maintained, which was evidenced by the increased levels of reactive oxygen species in MCF-7 cell cultures. This research proves the effective use of PS and opens a great field to research the PS functionality. More examples are represented in Table 2.

\subsection{Toxicity in NP}

PS have occasional reports of hypersensitivity following their topical and intramuscular administration $[59,88]$. However, the PS concentrations are crucial to establish biosecu- 
rity in their application. For example, Elmowafy et al. [75] reported a cell death of around $70 \%$ in cells exposed to polycaprolactone (PCL) NP stabilized with PS-80 at high concentration $(100 \mu \mathrm{g} / \mathrm{mL})$. Contrariwise, the same NP stabilized with PS-80 at low concentration $(1.56 \mu \mathrm{g} / \mathrm{mL})$ did not present cytotoxicity.

However, high cytotoxicity can be helpful when the nanoparticle application involves one type of cancer. For example, Nguyen et al. [64] developed PLGA NP to entrap artesunate (an anti-malarial agent) and tested the anticancer effect. The nanoparticle system presented a particle size of around $150 \mathrm{~nm}$ with PS-80 as stabilizer, with a $23.6 \pm 0.61 \%$ of drug loading capacity. The cytotoxicity of the artesunate entrapped in nanoparticulate systems was higher than the artesunate alone in SCC7, A549, and MCF7 culture cells. Contrariwise, when the aim is to improve drug therapy, high cytotoxicity can be a problem, and the particles' redesign is necessary. For example, Chang et al. [89] developed a PLGA NP system to enhance the transport throughout the BBB and evaluated the effect of PS-20. In this study, the authors assessed the cytotoxicity following the tight junction aperture. The authors described the high toxicity of the NP stabilized with PS-20, evidenced by a high sucrose endothelial permeability coefficient $\mathrm{Pe}>2 \times 10^{-3} \mathrm{~cm} / \mathrm{min}$ after $1 \mathrm{~h}$ of incubation. This test was crucial to eliminate the use of the PS-20 NP in the subsequent experiments.

\subsection{Advantages and Disadvantages}

The physicochemical properties of PS make them a great stabilizer in nanoparticle systems. For example, PS concentration can directly adjust the size of the adequate nanoparticle. The use of PS also confers high stability in the formulation process as well as in biological systems. Furthermore, PS increase the NP's bioavailability by decreasing the interaction with plasma proteins and increasing the cellular uptakes to cross biological barriers [79].

However, the concentration of PS in NP should be formulated carefully because high concentrations can alter the fluidity of barriers and can occur hypersensitivity reactions. Inversely, the use of low concentrations could compromise the efficacy or stability of the NP during storage. Therefore, the development of analytical methods that quantify the amount of PS present on the surface of the NP takes relevance. These methods aim to monitor and solve the optimum amount of PS [61,90-92], avoiding undesirable reactions.

In certain circumstances, the pharmaceutical storage and manufacturing conditions could catalyze the PS hydrolysis and autooxidation, compromising the NP's stability [57]. Moreover, the lack of uniformity in commercial PS is caused by monoesters and polyesters of polyoxyethylene (POE), and POE sorbitan and POE isosorbide fatty acid esters, which are typical products during the synthesis reactions. The inevitable presence of these products affects the PS final chemical composition and performance in chemical, biological, or mechanical stimuli. Although the variation is not exclusive to specific suppliers, the variation among batches is common [93].

\section{Polyvinyl Alcohol}

PVA is a linear synthetic, amphiphilic, semicrystalline, biocompatible, biodegradable, highly flexible, and nontoxic polymer that functions as an emulsifying agent by lowering the solutions interfacial tensions [94,95]. Its capacity to form relatively small particles and uniform size distribution makes it an appropriate candidate for biomedical applications [96-99]. In addition, PVA stabilizes emulsions because a fraction of PVA remains associated with the NP by forming an interconnected network with the polymer at the interface [100]. PVA is produced only by indirect methods [101-103], generally by hydrolysis or methanol transesterification (methanolysis) of polyvinyl-acetate (PVAc) [104,105], and the result is a hydrophilic polymer with a simple structure having a pendant hydroxyl group [95] that is resistant to many solvents [106]. In this respect, PVA is soluble in highly polar and hydrophilic solvents, such as Dimethyl Sulfoxide (DMSO), NMethyl Pyrrolidone (NMP), Ethylene Glycol (EG), and water (the most important solvent of PVA) [107]. On the other hand, PVA is resistant to oil, grease [108], and some solvents such 
as ethyl acetate, acrylonitrile, acetonitrile, and ammonia [109,110]. The resistance to most organic compounds and solvents can be advantageous; for example, PVA-based materials may protect packaged products from secondary contamination by those solvents [108].

\subsection{Physicochemical Properties}

The physicochemical and mechanical properties of PVA vary according to the degree of polymerization (DP) and degree of hydrolysis (DH) (see Section 4.2). Differences include water-solubility, adhesion and mechanical strength, gas barrier and aging resistance, thermostability, chemical resistance, film-forming ability, low fouling potential, $\mathrm{pH}$ stability, viscosity, high polar character, and easy processability [111-114]. PVA has a white to yellowish color [101]. The melting point is $228^{\circ} \mathrm{C}$ for fully hydrolyzed grades and $180-190{ }^{\circ} \mathrm{C}$ for partially hydrolyzed grades [115], due to the content and distribution of acetyl groups, tacticity, and water content [101]. The principal solvent of PVA is water [116], and the HLB value is 18 [117].

\subsection{Types}

PVA is generally derived from PVAc through partial or total hydrolysis to remove the acetate groups; then, there are types of PVA according to DP and DH [105,106,115,118,119]. PVA is commercially available in grades according to DH and viscosity. Partially hydrolyzed grades range from 84.2 to $89.0 \%$, moderately hydrolyzed from 92.5 to $96.5 \%$, and the completely hydrolyzed from 98.0 to $99.0 \%$ [94,101,119,120]. PVA hydrolyzed at 40 and $80 \%$ have a molecular weight of 72,000, and 9000-10,000, respectively [94,119]. There is an inverse relationship between molecular weight and DH. Lower molecular weight results in low viscosity, less aqueous solubility, and high flexibility, while lower DH results in increased solubility, flexibility, water selectivity, and adhesion to hydrophobic surfaces [108,120].

\subsection{Uses}

PVA is the world's most-used synthetic polymer and is included in the Handbook of Pharmaceutical Excipients [115]. Its versatility and properties have attracted interest from several industrial applications [94]. In medicine, PVA is convenient because it has low protein absorption and chemical resistance [121]. Thus, it has been used for applications such as controlled drug delivery systems [106], soft contact lenses [96,106], eye drops [122], embolization particles [123,124], tissue adhesion barriers [125,126], transdermal patches and jellies for the skin [115], and as artificial cartilage and meniscus [106,127]. Moreover, PVA helps dissipate heat and prolongs electronic devices' lifetime [128], is helpful for wastewater treatment [129-132], as well as in the industrial, commercial, and food sectors [106,133-140].

\subsection{Derivatives}

As mentioned, PVA is very versatile, and with some physical or chemical modifications, its properties can be modulated to improve its performance as a drug targeting and stabilizer, among other benefits [120]. For biomedical purposes, physical modifications of PVA like freeze-thawing [141], annealing [120,142], irradiation [143], and composites [144,145] are preferred to avoid any possibility of toxic residues [139]. In addition, these modifications cause molecular rearrangement by forming more crystalline regions [120].

Chemical modifications by crosslinking to PVA can be done through different techniques due to its hydrophilic characteristic. In theory, it can be done using any compound capable of reacting with -OH groups [132,146] such as aldehydes, dialdehydes like glutaraldehyde [147-149], carboxylic acids (lactic acid, maleic acid, sulfosuccinic acid) through esterification [146,150-152], sodium tetraborate [153], epichlorohydrin [154,155], and carboxymethyl [156] among others. These modifications alter physical and mechanical properties, reducing water solubility, and increasing polymer rigidity and chemical stability [120,132,157-160]. 


\subsection{Examples of NP Applications}

PVA is highly effective as a colloidal protector and stabilizer of suspensions. For example, polymer nanolatexes are obtained through emulsion polymerization. The use of PVA as the sole stabilizer helped obtain an adjustable NP size from 60 to $100 \mathrm{~nm}$ with a PDI between 0.05 to 0.07 [161]. PLGA-PVA NP loaded with chitosan-dextran sulfatedoxorubicin were designed and successfully delivered doxorubicin to MCF-7-DOX-R cells [162], obtaining the desired anti-proliferative effects. A poly(acrylic acid) (PAA)-bPVA double-hydrophilic block copolymer, with a $\mathrm{pH}$ - and IS-responsive block (PAA) was used to stabilize $\gamma-\mathrm{Fe}_{2} \mathrm{O}_{3} \mathrm{NP}$, improving its colloidal stability for its potential application for remotely magnetically triggered drug release to some tumor site [163]. Eudragit ${ }^{\circledR}$ L100 NP loaded with ketorolac tromethamine with a size of $153.7 \mathrm{~nm}$, a PDI of 0.318 , a zeta potential of $-16.9 \mathrm{mV}$, and DL of $36.3 \%$ were successfully incorporated in PVAhydroxyethyl cellulose (HEC) films for ophthalmic drug delivery system [164]. More examples are presented in Table 3. 
Table 3. Nanoparticulate formulations stabilized with PVA.

\begin{tabular}{|c|c|c|c|c|c|c|c|c|}
\hline Polymer & Surfactant & $\begin{array}{c}\text { NP Size } \\
(\mathrm{nm})\end{array}$ & PDI & $\begin{array}{l}\text { Z-Potential } \\
\text { (mV) }\end{array}$ & Drug & EE or DL & Application & Reference \\
\hline PLGA & $2 \%$ & $215.3 \pm 23$ & 0.071 & $-10.3 \pm 2.3$ & Chlorogenic acid & $\mathrm{DL}=2.25 \pm 0.21 \%$ & $\begin{array}{l}\text { As a promotor of type } \\
17 \text { collagen production }\end{array}$ & [165] \\
\hline PLGA & $\begin{array}{c}1-2 \% w / v \\
\text { and } 1.5 \% w / v\end{array}$ & $150 \pm 10.4$ & $0.081 \pm 0.030$ & 17.7 & IFN-beta-1a & $\mathrm{EE}=96.2 \%$ & $\begin{array}{l}\text { To diminish symptoms of } \\
\text { relapsing-remitting } \\
\text { multiple sclerosis }\end{array}$ & [166] \\
\hline PLGA & $0.1 \%$ & $213.8 \pm 34.99$ & $0.232 \pm 0.021$ & $-52.6 \pm 9.483$ & $\begin{array}{l}\text { Curcumin and } \\
\text { ovalbumin }\end{array}$ & $\begin{array}{c}\mathrm{EE}=30 \% \text { Cur; } \\
16 \% \text { Ova }\end{array}$ & $\begin{array}{c}\text { Use as sublingual } \\
\text { immunotherapy (SLIT) in a } \\
\text { mouse model of } \\
\text { rhinitis allergic }\end{array}$ & [167] \\
\hline PLGA & $2 \%$ & $\begin{array}{c}172.6 \pm 6.20 \\
\text { to } 271.9 \pm 18.2\end{array}$ & $\begin{array}{c}0.070 \pm 0.02 \\
\text { to } 0.301 \pm 0.03\end{array}$ & N.A. & Ketoconazole & $\begin{array}{c}\mathrm{EE}=94.99 \% \pm 3.45 \\
\text { to } 97.53 \% \pm 2.33\end{array}$ & $\begin{array}{l}\text { Treatment against } \\
\text { Candida albicans }\end{array}$ & [168] \\
\hline PLGA & $2 \%$ & $\begin{array}{c}198.6 \pm 5.4 \\
\text { (before freeze-drying) } \\
299.8 \pm 2.2 \\
\text { (after freeze-drying) } \\
\end{array}$ & $\begin{array}{l}0.160 \pm 0.033 \text { (before) } \\
0.412 \pm 0.028 \text { (after) }\end{array}$ & $\begin{array}{l}-20.8 \pm 1.4 \text { (before) } \\
-16.6 \pm 1.1 \text { (after) }\end{array}$ & Bevacizumab & $\begin{array}{c}\mathrm{DL}=1.62 \pm 0.01 \% \\
\text { (before } \\
\text { freeze-drying) }\end{array}$ & Antiangiogenic therapy & [169] \\
\hline PLGA & $0.3 \%(w / v)$ & 140 & 0.463 & N.A. & Farnesol & N.A. & $\begin{array}{l}\text { Antibiofilm activity, against } \\
\text { Candida albicans }\end{array}$ & [170] \\
\hline PLGA & $0.5 \%$ to $5 \%$ & $127 \pm 0.90$ to $289 \pm 1.56$ & $\begin{array}{c}0.191 \pm 2.66 \\
\text { to } 0.259 \pm 2.67\end{array}$ & -30.43 to -30.89 & Bicalutamide & N.A. & $\begin{array}{l}\text { For the treatment of } \\
\text { prostate cancer }\end{array}$ & [171] \\
\hline PLGA & $1 \%$ & $183.7 \pm 72.21$ & N.A. & $-41.1 \pm 4.81 \mathrm{mV}$ & p66shc siRNA & $\mathrm{EE}=32.3 \%$ & $\begin{array}{l}\text { To ameliorate neuropathic } \\
\text { pain following spinal } \\
\text { nerve ligation }\end{array}$ & [173] \\
\hline PLGA & $1.0 \%(w / v)$ & $110.0 \pm 41.0$ & N.A. & N.A. & 17 beta-estradiol & N.A. & $\begin{array}{l}\text { To improve low bone mineral } \\
\text { density of cancellous bone } \\
\text { caused by osteoporosis }\end{array}$ & [174] \\
\hline PLGA & $4 \%$ & $211 \pm 74$ & N.A. & $-14.2 \pm 0.8$ & Thioridazine & $\mathrm{DL}=26.5 \%$ & $\begin{array}{l}\text { To reduce toxicity against } \\
\text { mycobacterial infection } \\
\text { in zebrafish }\end{array}$ & [175] \\
\hline PLGA & $1 \%$ & $198 \pm 0$ & $0.16 \pm 0.01$ & $-78 \pm 1$ & Combretastatin A4 & $\begin{array}{c}\mathrm{EE}=32 \pm 3 \% \\
\mathrm{DL}=0.41 \pm 0.02 \%\end{array}$ & $\begin{array}{c}\text { To improve physicochemical } \\
\text { characteristics of } \\
\text { combretastatin A4, a natural } \\
\text { potent tubulin } \\
\text { polymerization inhibitor }\end{array}$ & [176] \\
\hline
\end{tabular}


Table 3. Cont

\begin{tabular}{|c|c|c|c|c|c|c|c|c|}
\hline Polymer & Surfactant & $\begin{array}{l}\text { NP Size } \\
(\mathrm{nm})\end{array}$ & PDI & $\begin{array}{l}\text { Z-Potential } \\
\text { (mV) }\end{array}$ & Drug & EE or DL & Application & Reference \\
\hline PLGA & $1 \%$ & $119 \pm 9$ to $206 \pm 27$ & 0.220 to 0.401 & -4.38 to -5.24 & Curcumin & $\begin{array}{l}\mathrm{EE}=77.81 \text { to } 92.64 \% \\
\mathrm{DL}=7.86 \text { to } 10.53 \%\end{array}$ & $\begin{array}{c}\text { Toxicity on human } \\
\text { glioblastoma U87MG cells }\end{array}$ & [177] \\
\hline PLGA & $0.5 \% w / v$ & 186.6 & 0.108 & -28.8 & Recombinant ArgF & $\begin{array}{l}\mathrm{EE}=76 \% \\
\mathrm{DL}=2.6 \%\end{array}$ & $\begin{array}{l}\text { For potential use for the } \\
\text { prevention of Mycobacterium } \\
\text { bovis infection }\end{array}$ & [178] \\
\hline PLGA & $5.21 \mathrm{mg} / \mathrm{mL}$ & $202.8 \pm 2.64$ & $0.17 \pm 0.016$ & N.A. & Resveratrol & $\mathrm{EE}=89.32 \pm 3.51 \%$ & For prostate cancer cells & [179] \\
\hline PLGA & $1 \%$ & 225.9 & 0.257 & -10.9 & $\begin{array}{l}\text { Curcumin and } \\
\text { Niclosamide }\end{array}$ & $\begin{array}{c}\mathrm{EE}=58.31 \% \text { Cur and } \\
\text { 84.8\% Nic } \\
\mathrm{DL}= \\
=2.92 \% \text { Cur and } \\
\\
4.24 \% \mathrm{Nic}\end{array}$ & $\begin{array}{l}\text { To improve therapeutic effect } \\
\text { on breast cancer cells }\end{array}$ & [180] \\
\hline PLGA & $0.5 \% w / w$ & $496 \pm 8.5$ & 0.607 & $-18.41 \pm 3.14$ & Rivaroxaban & $\begin{array}{l}\mathrm{EE}=87.9 \pm 8.6 \% \\
\mathrm{DL}=9.5 \pm 1.6 \%\end{array}$ & $\begin{array}{l}\text { Anticoagulant medication to } \\
\text { prevent blood clots }\end{array}$ & [181] \\
\hline PLGA & $1 \% w / v$ & $110 \pm 1$ & $0.117 \pm 0.003$ & $-1.29 \pm 0.35$ & Doxorubicin & $\mathrm{EE}=80 \%$ & $\begin{array}{l}\text { For chemotherapy of } \\
\text { glioblastoma }\end{array}$ & [182] \\
\hline PLGA & $1 \% w / v$ & $527 \pm 50.21$ & 0.26 & N.A. & $\begin{array}{l}\text { Olmesartan } \\
\text { medoxomil }\end{array}$ & $\mathrm{EE}=78.65 \pm 4.31 \%$ & $\begin{array}{c}\text { To increase the bioavailability } \\
\text { of the drug to treat } \\
\text { hypertension }\end{array}$ & [183] \\
\hline PLGA & $1 \% w / v$ & $180 \pm 8$ & 0.04 & $-8.59 \pm 0.20$ & $\begin{array}{l}\text { Paclitaxel and } \\
\text { methotrexate }\end{array}$ & $\begin{array}{c}\mathrm{EE}=70 \% \text { MTX } \text { and } \\
88 \% \text { PTX } \\
\mathrm{DL}=4 \% \text { MTX and } \\
5 \% \text { PTX }\end{array}$ & $\begin{array}{l}\text { Treatment against } \\
\text { glioblastoma }\end{array}$ & [184] \\
\hline PLGA & $3 \% w / v$ & $152.8 \pm 2.65$ & $0.187 \pm 0.024$ & $-30.9 \pm 1.67$ & $\begin{array}{c}\text { Lipophosphoglycan } \\
\text { molecule (LPG) and } \\
\text { leishmania antigen } \\
\text { (ALA) }\end{array}$ & $\begin{array}{c}\mathrm{EE}=14 \% \mathrm{ALA} \\
28 \% \mathrm{LPG} \\
\mathrm{DL}=28 \% \mathrm{ALA} \\
12 \% \text { LPG }\end{array}$ & $\begin{array}{l}\text { For a potential nanovaccine } \\
\text { to prevent leishmaniasis }\end{array}$ & [185] \\
\hline PLGA & $0.5 \% w / v$ & 114.7 to 124.8 & 0.113 to 0.147 & N.A. & Diclofenac sodium & $\mathrm{EE}=41.4 \%$ to $77.8 \%$ & For inflammatory diseases & [186] \\
\hline PLGA & $3 \% w / v$ & $252.6 \pm 2.854$ & $0.209 \pm 0.008$ & $-23.7 \pm 1.36$ & Rutin & $\mathrm{EE}=81 \pm 5 \%$ & $\begin{array}{l}\text { As a candidate for further } \\
\text { multidisciplinary studies } \\
\text { (support blood circulation, } \\
\text { allergies, viruses, etc.) }\end{array}$ & [187] \\
\hline PLGA & $4 \% w / v$ & $182.2 \pm 11.40$ & $0.147 \pm 0.01$ & N.A. & Doxorubicin & $\begin{array}{l}\mathrm{EE}=75.3 \% \\
\mathrm{DL}=4.9 \%\end{array}$ & $\begin{array}{l}\text { To arrest glioblastoma } \\
\text { growth via } \\
\text { intranasal delivery }\end{array}$ & [188] \\
\hline PLGA & $3 \%$ & $\begin{array}{l}191.92 \pm 2.3 \\
\text { to } 273.70 \pm 1.9\end{array}$ & $\begin{array}{c}0.070 \pm 0.014 \\
\text { to } 0.237 \pm 0.030\end{array}$ & $\begin{array}{c}-6.87 \pm 0.1 \\
\text { to }-11.5 \pm 0.4\end{array}$ & Dexamethasone & $\begin{array}{c}\mathrm{EE}=94.39 \pm 2.70 \% \\
\text { to } 95.02 \pm 2.98 \% \\
\mathrm{DL}=3.27 \pm 0.58 \% \text { to } \\
5.43 \pm 0.63 \%\end{array}$ & $\begin{array}{l}\text { Potential treatment of oral } \\
\text { precancerous lesions }\end{array}$ & [189] \\
\hline
\end{tabular}


Table 3. Cont.

\begin{tabular}{|c|c|c|c|c|c|c|c|c|}
\hline Polymer & Surfactant & $\begin{array}{c}\text { NP Size } \\
(\mathrm{nm})\end{array}$ & PDI & $\begin{array}{l}\text { Z-Potential } \\
(\mathrm{mV})\end{array}$ & Drug & EE or DL & Application & Reference \\
\hline PLGA & $2 \% w / v$ & $\begin{array}{c}229.5 \pm 38.4 \\
\text { to } 379.2 \pm 21.6\end{array}$ & $\begin{array}{l}0.36 \pm 0.02 \\
\text { to } 0.73 \pm 0.13\end{array}$ & $\begin{array}{l}-1.2 \pm 1.1 \\
\text { to }-3.9 \pm 0.5\end{array}$ & $\begin{array}{l}\text { Ethanolic Extract } \\
\text { of Propolis }\end{array}$ & $\begin{array}{c}\mathrm{EE}=89.90 \pm 0.8 \% \text { to } \\
92.1 \pm 0.5 \% \\
\mathrm{DL}=28.6 \pm 1.1 \% \text { to } \\
56.7 \pm 3.4 \%\end{array}$ & $\begin{array}{l}\text { As a treatment against } \\
\text { Candida albicans }\end{array}$ & [190] \\
\hline PLGA & $1 \%$ & $97.36 \pm 2.01$ & $0.263 \pm 0.004$ & $-17.98 \pm 1.09$ & Thymoquinone & $\begin{aligned} \mathrm{EE} & =82.49 \pm 2.38 \% \\
\mathrm{Dl} & =5.09 \pm 0.13 \%\end{aligned}$ & For the treatment of epilepsy & [191] \\
\hline PLGA & $2 \% w / v$ & $200 \pm 05$ & $0.05 \pm 0.02$ & N.A. & Budesonide & $\mathrm{EE}=85 \pm 3.5 \%$ & $\begin{array}{l}\text { To target the inflammation } \\
\text { of mucosa }\end{array}$ & [192] \\
\hline PLGA & $1 \% w / v$ & 118 to 279 & $0.103-0.581$ & N.A. & Quercetin & $\begin{array}{c}\mathrm{EE}=73.55 \pm 2.11 \% \\
\text { to } 86.48 \pm 1.67 \%\end{array}$ & $\begin{array}{l}\text { Potential vehicle for the } \\
\text { antioxidant quercetin }\end{array}$ & [194] \\
\hline PLGA & $5 \% w / v$ & $105 \pm 3$ & N.A. & $-36 \pm 5$ & $\begin{array}{l}\text { Surfactant Protein D } \\
\text { (SP-D) }\end{array}$ & $\mathrm{EE}=59 \pm 4 \%$ & $\begin{array}{l}\text { As a potential treatment for } \\
\text { respiratory distress } \\
\text { syndrome in preterm infants }\end{array}$ & [195] \\
\hline PLGA & $2 \% w / v$ & $154 \pm 4.56$ & 0.29 & -18.4 & Ursolic Acid & $\begin{array}{l}\mathrm{EE}=40 \pm 3.24 \% \\
\mathrm{DL}=4 \pm 1.12 \%\end{array}$ & $\begin{array}{l}\text { Potential vehicle to deliver } \\
\text { the drug against different } \\
\text { bearing cell lines }\end{array}$ & [196] \\
\hline PLGA & $0.5-1.5 \% w / v$ & 200 & N.A. & -17.5 & Zaleplon & $\mathrm{DL}=5 \%$ & For treatment of insomnia & [197] \\
\hline PLGA & $1 \% w / w$ & $244.3 \pm 4$ to $262.8 \pm 7$ & N.A. & $\begin{array}{c}-8.8 \pm 0.8 \text { to }-17.4 \\
\pm 1.0\end{array}$ & Quercetin & $\mathrm{EE}=96.2$ to $97.8 \%$ & To treat foodborne pathogens & [198] \\
\hline PLGA & $1 \%(w / v)$ & $211 \pm 3$ & $0.211 \pm 0.009$ & N.A. & Clofazimine & $\mathrm{DL}=12 \pm 1 \%$ & $\begin{array}{l}\text { To decrease toxicity of the } \\
\text { antimicrobial drug }\end{array}$ & [199] \\
\hline PLGA & $1.5 \%(w / v)$ & $268 \pm 2.7$ & $0.110 \pm 0.026$ & N.A. & Atrazine & $\mathrm{EE}=31.6$ to $50.5 \%$ & $\begin{array}{l}\text { Potential herbicide release } \\
\text { system for agriculture }\end{array}$ & [200] \\
\hline PLGA & $1 \%$ & $192.6 \pm 3.5$ & $0.234 \pm 0.008$ & -32.4 & Atenolol & $\mathrm{EE}=71.65 \pm 1.8 \%$ & $\begin{array}{l}\text { Drug carrier of a } \beta \text {-blocker } \\
\text { for cardiovascular disorders }\end{array}$ & [201] \\
\hline PLGA & $2 \%(w / v)$ & $294 \pm 15$ & $0.26 \pm 0.02$ & $-20.4 \pm 2.5$ & Insulin & $\mathrm{DL}=12.1 \pm 0.6 \%$ & $\begin{array}{l}\text { To optimize the PLGA } \\
\text { formulation and } \\
\text { lyophilization }\end{array}$ & [202] \\
\hline PLGA & $2.5 \%$ & $184 \pm 7$ & $0.19 \pm 0.01$ & -21.7 & Rhodamine-B & $\mathrm{EE}=40 \pm 2.94 \%$ & $\begin{array}{l}\text { Potential probes for the drug } \\
\text { delivery in cardiac myocytes }\end{array}$ & [203] \\
\hline PLGA & $2 \% w / v$ & $133.3 \pm 10.4$ & $0.087 \pm 0.009$ & $-16.1 \pm 4.5$ & Trastuzumab & $\mathrm{EE}=42.8 \pm 1.6 \%$ & $\begin{array}{l}\text { Potential vehicle for } \\
\text { therapeutic antibodies to } \\
\text { avoid current limitations }\end{array}$ & [204] \\
\hline
\end{tabular}


Table 3. Cont.

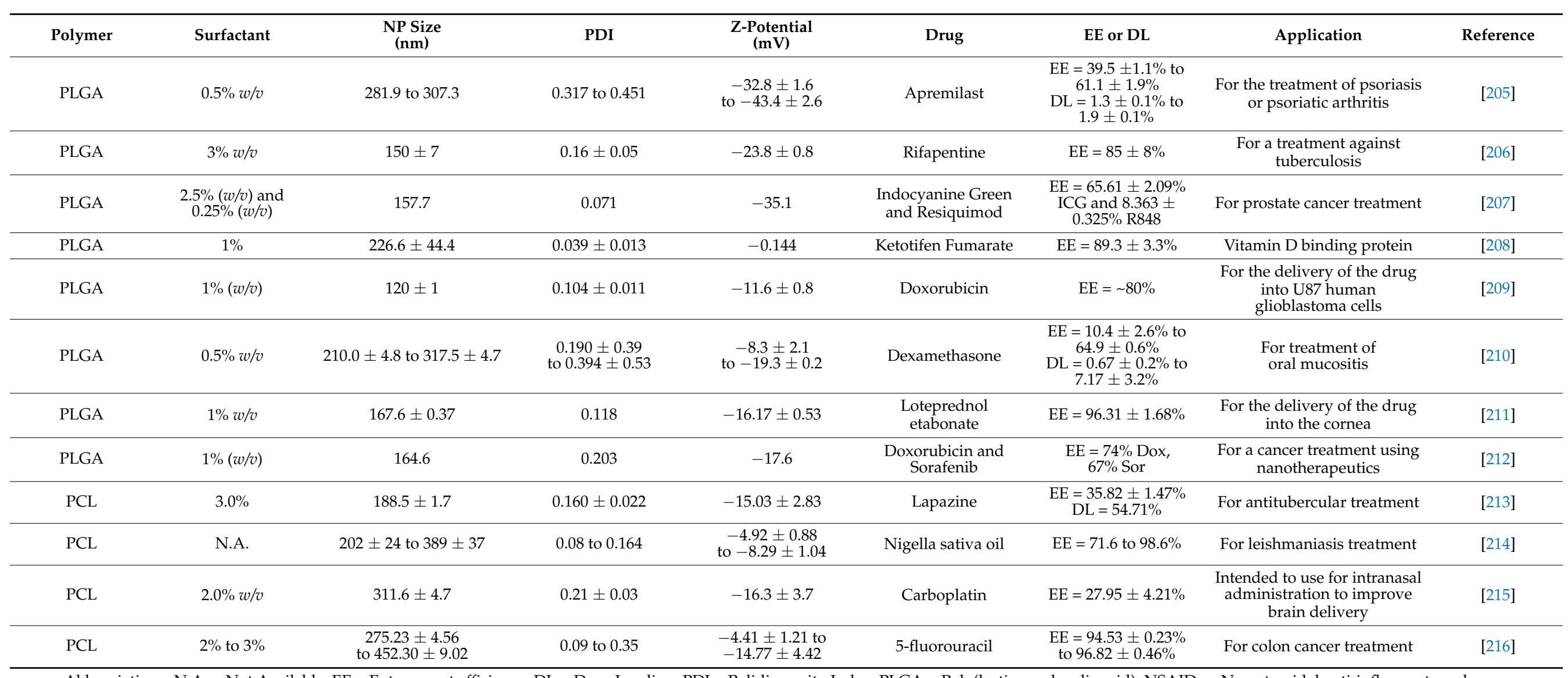

Abbreviations: N.A. = Not Available; EE = Entrapment efficiency; DL = Drug Loading; PDI = Polidispersity Index; PLGA = Poly(lactic-co-glycolic acid); NSAIDs = Non-steroidal anti-inflammatory drugs. 


\subsection{Toxicity in NP}

Sprague-Dawley rats were fed with PVA (2000, 3500, and $5000 \mathrm{mg} / \mathrm{kg} /$ day) for up to 90 days, and no toxicological effects were observed. When tested in NP, similar results were obtained. PLGA/PVA NP tested in Human-like-THP-1 macrophages found less cytotoxicity at high concentration $(1 \mathrm{mg} / \mathrm{mL})$ than other stabilizers [217]. Polymeric NP of chitosan-g-poly(methyl methacrylate) (PMMA) and PVA-g-PMMA were ionotropically crosslinked with sodium tripolyphosphate to mask the positive charge and successfully avoid toxicity after $0.8 \mathrm{mg} / \mathrm{kg}$ intranasal administration of NP in Hsd:ICR mice [218]. In addition, tamoxifen-loaded-PLGA/PVA NP exhibited low toxicity in C127I cells (up to $10 \mu \mathrm{g} / \mathrm{mL}$ ) and rats with 12-dimethylbenz(a)anthracene-induced breast cancer (3 mg/kg) [219]. Paclitaxel-loaded PVA-g-PLGA NP tested in RbVSMC cells presented a $30 \%$ reduction in cell viability at $300 \mu \mathrm{g} / \mathrm{mL}$, while biocompatibility was confirmed to $370 \mu \mathrm{g} / \mathrm{mL}$ in drug-free NP [220].

\subsection{Advantages and Disadvantages}

The high biodegradability in the environment may be the most desirable characteristic of PVA because it can easily be degraded by bacteria (Gram-negative and Gram-positive) and Penicillium sp $[102,105,115,140]$. Furthermore, PVA-coated NP exhibit a low level of non-specific interaction with solutes like cell adhesion proteins due to its hydrophilic nature [221], which could be beneficial or harmful. On the other hand, it has been reported that a fraction of PVA forms a stable matrix on the polymeric surface that cannot be removed, affecting the physical properties of NP and their interactions with the surrounding environment [222]. Finally, a problem with the reports of PVA-coated NP is that the molecular weight and the hydrolysis percentage are generally not reported, affecting the reproducibility of the studies.

\section{Poloxamers}

Poloxamers, also known as Pluronic ${ }^{\circledR}$, are tri-block copolymers with amphiphilic properties, which can be found in three different forms: liquid, paste, and flake. They were commercially first produced by BASF Corporation in 1950 [223,224]. These block copolymers contain two blocks of the hydrophilic POE separated by one block of the hydrophobic poly(propylene oxide)(PPO) in an arrangement A-B-A (POE-PPO-POE) [225]. The possibility of modifying the amount and relation between POE and PPO in the poloxamer structure allows the obtention of different physicochemical characteristics. Poloxamers present surfactant properties and are widely utilized in the stabilization of nanostructured systems. Furthermore, these copolymers can interact with cells and cell membranes, providing a high potential to be applied in the design of new biomaterials and novel nanomedicines (Figure 3) [226,227].

\subsection{Physicochemical Properties}

Poloxamers are synthesized by sequential polymerization of ethylene oxide and $\mathrm{PPO}$ units in sodium hydroxide and potassium hydroxide. Their chemical formula is $\mathrm{HO}\left[\mathrm{CH}_{2} \mathrm{CH}_{2} \mathrm{O}\right]_{x}\left[\mathrm{CH}\left(\mathrm{CH}_{3}\right) \mathrm{CH}_{2} \mathrm{O}_{y}\left[\mathrm{CH}_{2} \mathrm{CH}_{2} \mathrm{O}\right]_{x} \mathrm{OH}\right.$, where $y$ is higher than 14 . Depending on the $x$ and $y$ values, these copolymers present different amphiphilic properties based on their HLB values. The physicochemical characteristics of poloxamers could be modified by changing the POE and PPO relation mass, obtaining different sizes, lipophilicity, and hydrophilicity. Regularly, the molar mass ratio between POE and PPO blocks ranges from 8:2 to 9:1, derived from the coexistence of hydrophilic and hydrophobic sections in the poloxamers structure. These copolymers present a high temperature-dependent selfassembling characteristic as well as thermo-reversible properties. Solutions of poloxamers with concentrations higher than their CMC produce gels at temperatures above their sol-gel transition temperature. Additionally, PPO blocks dehydrate at high temperatures, and it is less soluble in water, which triggers the formation of the micelles with the dehydrated PPO core and hydrated POE shell. Consequently, depending on the main properties needed for 
the application, appropriate physical and chemical modifications could be applied in the poloxamer synthesis. Interestingly, several reports demonstrated that poloxamers could decrease the cell membrane microviscosity (membrane fluidization) due to the presence of hydrophobic PPO chains $[223,228]$. Furthermore, it has been reported that poloxamers could reduce multidrug resistance, inducing a dramatic reduction in ATP levels in cancer and barrier cells, and inhibiting drug efflux transporters [227,229,230].

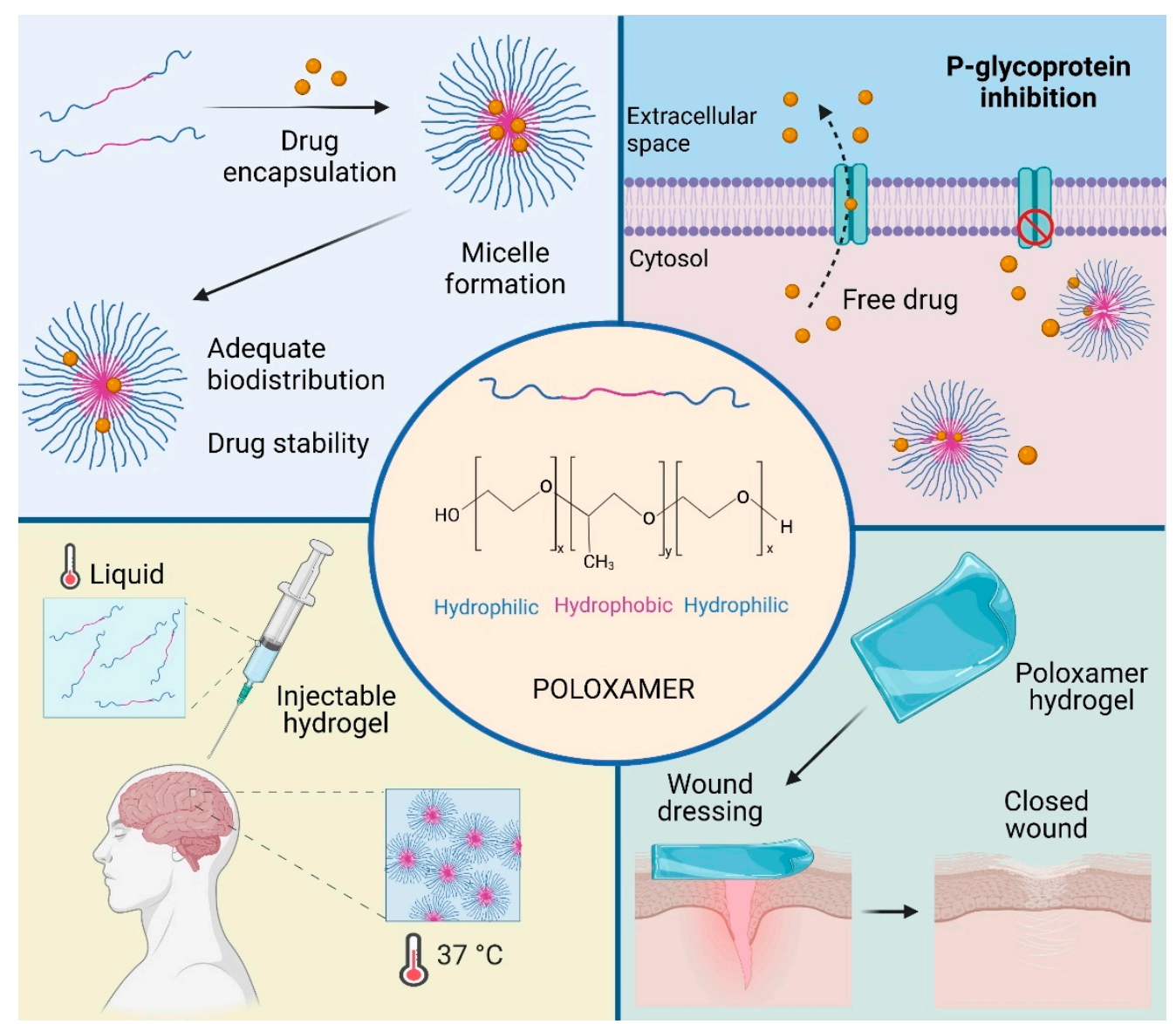

Figure 3. Poloxamer applications. Poloxamers could be used in several fields according to their biological and physicochemical properties. For example, micelles are effectively used as drug carriers. Moreover, they presented the ability to inhibit drug efflux transporters. Poloxamers represent an attractive alternative to tissue engineering, both as injected hydrogel, exploiting their thermosensitivity capacity, and structured hydrogel for wound dressing.

\subsection{Types}

As we mentioned, poloxamers are polymorph materials covering a range of gelation states from liquid to paste and solid, depending on the molar mass ratios between the POE and PPO blocks [224]. This class of A-B-A copolymers offers a pool of more than 50 materials with molecular weights ranging from 1600 to $14,600 \mathrm{Da}$ that present different properties [231]. In the commercial nomenclature of these copolymers, the name is composed by a letter that indicates the morphism of each copolymer: liquid (L), paste $(\mathrm{P})$, and flake (F), followed by two or three digits, which is related to their structural parameters [224,232]. For example, the Pluronic ${ }^{\circledR}$ known as L121 (poloxamer 401) has a liquid presentation with above 2,000 Da of molecular weight and HLB of 3; meanwhile, Pluronic ${ }^{\circledR}$ F68 (poloxamer 188) has an average molecular weight of $8,400 \mathrm{Da}$, a percentage of POE around $80 \%$, and an HLB value of 29 with flake morphology [231]. On the other hand, Pluronic ${ }^{\circledR}$ P123 (poloxamer 403) is a paste with an HLB value of 8 and an average molecular weight of 5,750 $\mathrm{Da}[224,233]$. 


\subsection{Uses}

The structural versatility of poloxamers makes them particularly attractive emulsifying, solubilizing, and dispersing ingredients for pharmaceutical formulation [234,235]. It has been reported that the incorporation of low molecular weight drugs into poloxamer micelles could increase drug stability and solubility, improving the pharmacokinetics and biodistribution. These polymeric micelles have been employed for the oral administration of tumor-specific and brain drugs [234,236,237]. In addition, these copolymers have been used as food additives. Moreover, due to their thermosensitivity, poloxamers can form hydrogels, injectable hydrogels, 3D scaffolds, micro/nanofibers, and cell carrier constructs; consequently, these copolymers have been utilized in tissue engineering and biomaterials fields [232,238-240].

\subsection{Derivatives}

The synthesis of chemically cross-linkable poloxamers has also been analyzed to enhance their mechanical properties. The chemical structure of poloxamers presents only reactive groups available for the modification at the end of the chains; thus, chemically cross-linkable groups can only be used to end-cap the triblock chain. Ethoxylsilane and methacrylate/acrylate are two groups employed for the crosslink of end-capping groups [241]. To introduce ethoxy silane end-capping group, (3-isocyanatopropyl) triethoxysilane can be utilized to react with the hydroxyl groups of poloxamers under the catalysis of 2-ethyl-hexanoate. For the coupling of methacrylate/acrylate, methacryloyl chloride/acryloyl chloride reacts with hydroxyl groups on both ends, resulting in higher mechanical properties [241,242]. In this context, in 2021, Popescu et al. developed a hydrogel from a natural polymer and poloxamer 407 obtained by thiol-acrylate photopolymerization to be employed as a wound dressing [243].

\subsection{Examples of NP Applications}

Poloxamers have been widely applied in nanotechnology as a stabilizer and nanoparticle shell component for different applications. In 2019, Del Prado et al. developed a system of PCL NP stabilized by poloxamer 188 [244]. The results suggested that the presence of poloxamer in the nanoparticle's surface produced a stable nanodispersion during six months of storage. Interestingly, the nanocarrier leads to a decrement in reactive oxygen species, which the authors attributed to the presence of poloxamer 188 [245]. Similarly, in 2021, the poloxamer 188 was employed as a stabilizer of rivaroxaban-loaded PLGA NP as a novel strategy for treating thrombotic disorders [246]. The nanosystem presented a spherical morphology with an average size of $200 \mathrm{~nm}$ and PDI of 0.09 , the latter suggesting a homogenous size distribution. Another poloxamer highly utilized as a stabilizer is the poloxamer 407. Recent research reported the evaluation of amphotericin-loaded PCL NP using poloxamer 407 as a surfactant [247]. The spherical nanocarriers presented a mean hydrodynamic particle size of $183 \mathrm{~nm}$ and encapsulation efficiency of $85 \%$. The elaboration of poloxamer 407-based NP also has been explored [248,249]. Another research reported NP of poloxamer 407 with a size around $100 \mathrm{~nm}$ and PDI of 0.122 ; the formulation exhibited appropriate properties to deliver chemotherapeutic agents [248]. Table 4 compiles examples of poloxamers formulated in nanoparticulate systems. 
Table 4. Nanoparticulate formulations stabilized with poloxamers.

\begin{tabular}{|c|c|c|c|c|c|c|c|c|}
\hline Polymer & Surfactant & $\begin{array}{c}\text { NP Size } \\
(\mathrm{nm})\end{array}$ & PDI & $\begin{array}{c}\text { Z-Potential } \\
\text { (mV) }\end{array}$ & Drug & EE or DL & Application & Reference \\
\hline PCL & F-127, $2 \%$ & 167 & 0.188 & $\sim 0$ & Amphotericin & $\mathrm{EE}=85 \%$ & $\begin{array}{c}\text { Increase the solubility of the drug } \\
\text { as treatment for } \\
\text { Leishmania infections }\end{array}$ & [247] \\
\hline Chitosan & F-127, 15\% & 146 & N.A & 5.09 & Curcumin & $\mathrm{EE}=61.7 \%$ & $\begin{array}{l}\text { Development of effective delivery } \\
\text { system with few side-effects }\end{array}$ & [250] \\
\hline PCL & $\begin{array}{l}\text { F-108, } 50 \% \\
\text { F- } 127,50 \% \\
\text { F- } 68,50 \%\end{array}$ & $\begin{array}{c}182 \\
184.7 \\
698.4\end{array}$ & $\begin{array}{l}0.2 \\
0.28 \\
0.88\end{array}$ & $\begin{array}{l}-11.7 \\
-1.6 \\
-6.03\end{array}$ & N.A & N.A & $\begin{array}{l}\text { Evaluation of the effect of } \\
\text { different surfactants }\end{array}$ & [251] \\
\hline PLGA & F- $68,0.5 \%$ & $160-170$ & $0.051 \pm 0.012$ & $-20.5 \pm 0.069$ & N.A & N.A & $\begin{array}{l}\text { Evaluation of the effect of } \\
\text { poloxamer as surfactant }\end{array}$ & [253] \\
\hline PCL/F-68 & PVA, $0.05 \%$ & $201.7 \pm 10.1$ & 0.096 & $-12.50 \pm 0.86$ & Docetaxel & $\begin{array}{c}\mathrm{EE}=69.1 \% \\
\mathrm{DL}=10 \%\end{array}$ & $\begin{array}{l}\text { Evaluation of the increased level of } \\
\text { uptake NP due to F-68 presence }\end{array}$ & [254] \\
\hline PCL & F-68, 2\% & $149.9 \pm 2.2$ & $0.087 \pm 0.05$ & N.A & Curcumin & $\begin{array}{l}\mathrm{EE}=96 \pm 0.95 \% \\
\mathrm{DL}=4.9 \pm 0.7 \%\end{array}$ & $\begin{array}{c}\text { Development of a potential } \\
\text { alternative } \\
\text { treatment for neuronal diseases } \\
\text { based on curcumin }\end{array}$ & [244] \\
\hline PS & $\begin{array}{l}\text { L61, } \\
\text { F-68, } \\
\text { F-108, } \\
\text { L121, } \\
\text { F-127 }\end{array}$ & $\begin{array}{c}97 \pm 1 \\
105 \pm 1 \\
110 \\
100 \pm 2 \\
108 \pm 1 \\
\end{array}$ & $\begin{array}{l}0.01 \\
0.03, \\
0.02, \\
0.02, \\
0.02\end{array}$ & $\begin{array}{l}-42 \pm 1 \\
-26 \pm 2, \\
-14 \pm 2, \\
-32 \pm 1 \\
-18 \pm 2 \\
\end{array}$ & N.A & N.A & $\begin{array}{l}\text { Analysis of polymer NP modified } \\
\text { with different types of poloxamers }\end{array}$ & [255] \\
\hline Chitosan & F-68 0.5\% & $252.80 \pm 7.46$ & $0.40 \pm 0.03$ & $17.50 \pm 0.93$ & Doxorubicin & $\mathrm{EE}=61.3 \pm 2.28 \%$ & $\begin{array}{l}\text { Fabrication of DOX-loaded } \\
\text { pH-responsive NP } \\
\text { for chemotherapy }\end{array}$ & [256] \\
\hline Silk sericin & $\begin{array}{l}\text { F-127 (1:5) } \\
\text { F-87 (1:5) }\end{array}$ & $\begin{array}{c}61.9 \pm 5.36 \\
103 \pm 1.0 \mathrm{~nm}\end{array}$ & $\begin{array}{l}0.21 \\
0.18\end{array}$ & N.A & $\begin{array}{l}\text { Inulin } \\
\text { Paclitaxel }\end{array}$ & $\mathrm{EE}=65 \pm 10 \%$ & $\begin{array}{l}\text { Development of silk sericin NP in } \\
\text { the presence of poloxamer for } \\
\text { successful delivery of both } \\
\text { hydrophobic and hydrophilic drugs }\end{array}$ & [257] \\
\hline PLGA/F-68 & PVA $1 \%$ & $179.4 \pm 11.2$ & $0.309 \pm 0.08$ & $-22.7 \pm 5.7$ & Paclitaxel & $\mathrm{EE}=65 \pm 8.3 \%$ & $\begin{array}{c}\text { Development of novel } \\
\text { PLGA:poloxamer blend NP for } \\
\text { intravenous administration } \\
\text { of paclitaxel }\end{array}$ & [258] \\
\hline PLGA/F-68/F-127 & PVA, $1 \%$ & $160 \pm 31$ & $0.671 \pm 0.03$ & $18.7 \pm 1.3$ & Curcumin & $\mathrm{EE}=90 \pm 2.1 \%$ & $\begin{array}{l}\text { Obtention of PLGA/poloxamer } \\
\text { blend NP and evaluation of their } \\
\text { interaction with serum proteins and } \\
\text { its internalization ability }\end{array}$ & [259] \\
\hline
\end{tabular}


Table 4. Cont

\begin{tabular}{|c|c|c|c|c|c|c|c|c|}
\hline Polymer & Surfactant & $\begin{array}{c}\text { NP Size } \\
(\mathrm{nm})\end{array}$ & PDI & $\begin{array}{l}\text { Z-Potential } \\
(\mathrm{mV})\end{array}$ & Drug & EE or DL & Application & Reference \\
\hline PLGA-Chitosan & F- $68,1 \%$ & $150.7 \pm 1.8$ & $0.16 \pm 0.03$ & $25.1 \pm 1.6$ & $\operatorname{miR}-34 a$ & $\mathrm{EE}=49 \pm 2.1 \%$ & $\begin{array}{l}\text { Anticancer treatment of } \\
\text { multiple myeloma }\end{array}$ & [260] \\
\hline PLGA-Chitosan & $\mathrm{F}-68,1 \%$ & $\sim 130$ & N.A & 30 & $\begin{array}{l}\text { Anti-hTERT } \\
\text { siRNA }\end{array}$ & N.A & $\begin{array}{l}\text { Block the growth of anaplastic } \\
\text { thyroid cancer xenograft }\end{array}$ & [261] \\
\hline Chitosan & F- $68,10-50 \%$ & $\sim 122$ & N.A & 23.63 & $\begin{array}{l}\text { Doxazosin } \\
\text { mesylate }\end{array}$ & $\begin{array}{l}\mathrm{EE}=99.9 \% \\
\mathrm{DL}=8.5 \%\end{array}$ & $\begin{array}{l}\text { Control release and enhancing the } \\
\text { bioavailability of } \\
\text { doxazosin mesylate }\end{array}$ & [262] \\
\hline PLGA & F-68, 1\% & $\sim 94$ & $0.091 \pm 0.010$ & -0.3 & Doxorubicin & $\mathrm{EE}=92 \%$ & Treatment of glioblastoma & [263] \\
\hline PLGA & P-85 & $156.7 \pm 3.9$ & $0.21 \pm 0.04$ & $-45.7 \pm 2.9$ & Doxorubicin & $\begin{array}{l}\mathrm{EE}=85.2 \pm 4.1 \% \\
\mathrm{DL}=7.3 \pm 1.2 \%\end{array}$ & Treatment of leukemia & [265] \\
\hline PLGA & P-85/PVA & $180.26 \pm 5.60$ & 0.184 & $-17.47 \pm 2.67$ & Docetaxel & $\begin{array}{c}\mathrm{EE}=82.7 \% \\
\mathrm{DL}=10 \%\end{array}$ & Breast cancer treatment & [266] \\
\hline Chitosan- $\gamma$ PGA & F-127, 0.25-1\% & $193.1 \pm 8.9$ & $0.29 \pm 0.02$ & $20.6 \pm 2.4$ & Curcumin & $\mathrm{EE}=52.8 \pm 4.7 \%$ & Wound regeneration & [267] \\
\hline PCL & F-127, $0.06 \%$ & $\sim 123.5$ & N.A & -29.6 & Chloramphenicol & $\mathrm{EE}=98.3 \%$ & $\begin{array}{l}\text { For treatment of MRSA-infected } \\
\text { burn wounds }\end{array}$ & [268] \\
\hline $\begin{array}{c}\text { Folated } \\
\text { F127/PLGA }\end{array}$ & F-127 & $107.6 \pm 4.25$ & $0.308 \pm 0.01$ & N.A & Paclitaxel & $\mathrm{EE}=3.4 \%$ & $\begin{array}{l}\text { Prolongation of the circulation time } \\
\text { of paclitaxel }\end{array}$ & [269] \\
\hline F-127 & F-127, $0.02 \%$ & $9.70 \pm 0.31$ & $0.195 \pm 0.029$ & $-27.01 \pm 0.20$ & Berberine & $\mathrm{EE}=87.6 \pm 1.52 \%$ & $\begin{array}{l}\text { Improve permeability and retention } \\
\text { in the skin }\end{array}$ & [270] \\
\hline PLGA & $\begin{array}{l}\text { F-127 and F-108, } \\
0.2 \%\end{array}$ & $\sim 115$ & $<0.1$ & -11.3 & N.A & N.A & Functionalization of polymeric NP & [271] \\
\hline F-127 & $\mathrm{F}-127,1.2 \%$ & $70 \pm 2.4$ & 0.12 & N.A & Gossypol & $\begin{array}{l}\mathrm{EE}=91.2 \pm 3.1 \% \\
\mathrm{DL}=9.1 \pm 0.42 \%\end{array}$ & Cancer drug release study & [272] \\
\hline Trimethyl chitosan & $\mathrm{F}-127,0.1 \%$ & $\sim 160$ & 0.140 & +20.1 & Methotrexate & $\begin{array}{l}\mathrm{EE}=93.6 \% \\
\mathrm{DL}=8.95 \%\end{array}$ & $\begin{array}{l}\text { Effective delivery of methotrexate } \\
\text { in osteosarcoma }\end{array}$ & [273] \\
\hline PLGA & F-127, $1 \%$ & $159.0 \pm 3.0$ & $0.099 \pm 0.042$ & $-15.4 \pm 0.7$ & Rose Bengal & $\mathrm{DL}=0.82 \pm 0.27 \%$ & $\begin{array}{l}\text { Evaluation of the effect of the } \\
\text { nanoparticle delivery system on the } \\
\text { biodistribution of the drug }\end{array}$ & [274] \\
\hline PLGA/F-68 & N.A. & 154 & 0.118 & $-25.2 \pm 1.1$ & PDGF-BB & $\mathrm{EE}=87 \pm 2 \%$ & $\begin{array}{l}\text { Development of injectable } \\
\text { controlled release device based on } \\
\text { polymeric NP for the delivery of } \\
\text { growth factors. }\end{array}$ & [275] \\
\hline
\end{tabular}

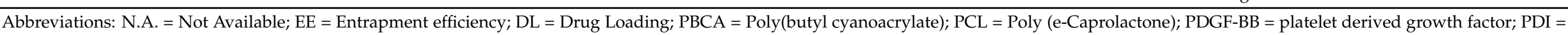

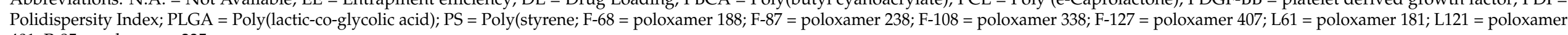
$401 ; \mathrm{P}-85=$ poloxamer 235. 


\subsection{Toxicity in NP}

Several studies have reported the use of poloxamers-based or -coated NP in cell culture, finding that the toxicity of these surfactants is relatively low [276]. For instance, Li et al. [277] reported that after 14 days of feeding with solutions of poloxamer 235/poly (lactic acid) NP at different concentrations, no deaths or treatment-related complications were observed in mice, even in the higher concentration treatment. In 2017, the enhanced viability of pancreatic islets due to nanosystems based on poloxamer $407 /$ chitosan and bilirubin entrapped into NP was reported [278]. In other work, a nanostructured system was developed based on poloxamer 407, and poloxamer 403 modified in the end chains with vitamin E succinate to encapsulate paclitaxel [279]. The cell viability was evaluated in bone marrow-derived macrophages and a human glioma U87 cell line. The NP presented no significant changes in viability of macrophages and high cytotoxicity in human glioma U87 cells, which was related to the therapeutic effect of the NP.

\subsection{Advantages and Disadvantages}

As mentioned, poloxamers exhibit characteristics that are very useful for the pharmaceutical and biomedical fields. For instance, thermosensitivity, high capacity to solubilize drugs, drug release properties, and the absence of toxicity in mucous membranes [240,280]. Furthermore, these safe materials present the ability to inhibit drug efflux transporters, representing an essential advantage for drug release systems. On the other hand, a disadvantage of these block copolymers is their fast degradation rate in vivo [281]. Additionally, it has been reported that Pluronic ${ }^{\circledR}$ copolymers presented low cytotoxicity and, remarkably, weak immunogenicity in topical and systemic administration. It is known that POE-PPOPOE copolymers are non-degradable; however, molecules with a molecular weight of 15 $\mathrm{kDa}$ or less are usually filtered by the kidney and cleared in urine [282]. On the other hand, in recent publications, the complement system activation by POE-containing polymers has been analyzed $[283,284]$. Authors suggested that these polymers could trigger acute hypersensitivity reactions or pseudoallergic reactions [283]. However, some evidence demonstrated that this effect is observed only in highly responsive patients to complement activation [285]. Consequently, the Pluronic coating must be carefully developed.

\section{Influence of Non-Ionic Surfactants on the Interaction with Biological Barriers}

The impact of surfactants on the physicochemical parameters of NP is not limited to stability phenomena. There is a significant influence of surface phenomena driven by surfactants and interactions at the cellular level $[8,286]$ (Figure 4). Therefore, it is possible to increase or decrease the interaction with cells according to the type of surfactant; even the vectorization process can be favored in a certain way. The influence of non-ionic surfactants on the passage through the main biological barriers involved in the pharmacokinetic processes is described below.

\subsection{Blood-Brain Barrier}

The BBB is a highly sophisticated brain barrier with tight junctions between endothelial cells and a foreign substance detection system; therefore, it represents a challenge for drug passage. Interestingly, Voigt et al. [18] conducted a blood-retina barrier passage study as a BBB model of fluorescent PBCA NP with different types of surfactants: non-ionic (PS-20, PS-80, polyethylene glycol monododecyl ether, poloxamer 188), anionic (sodium dodecyl sulfate (SDS), and cationic (dextran). The authors used real-time imaging of retinal blood and in vivo confocal neuroimaging during and after nanoparticle injection. The study revealed that non-ionic or even cationic surfactants allowed a successful BBB passage, while particle size and zeta potential had no influence. Furthermore, even when the authors decreased the size of the NP to $87 \mathrm{~nm}$ but added SDS to the non-ionic surfactant, they did not observe crossing in the BBB [18]. 


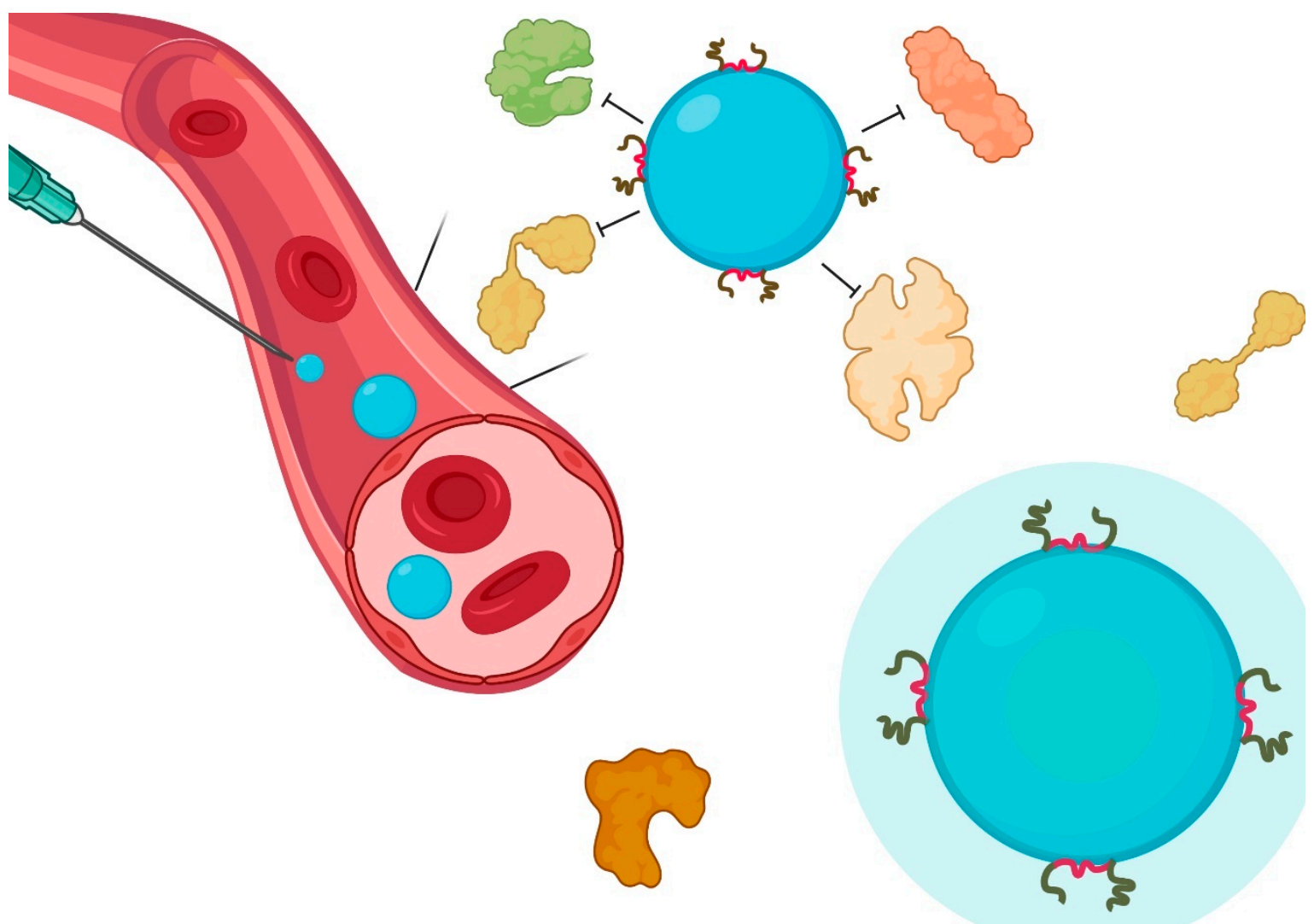

Figure 4. Interaction of non-ionic surfactants in biological systems. Adsorption of PS, PVA, or poloxamer allows a decrease in the deposition of proteins on the surface, increasing the circulation time. Local effects involve an absorption enhancer phenomenon with low inflammatory response.

\subsection{Intestinal}

Historically, the oral route has been the preferred drug administration route due to patient comfort, ease of application, and low treatment costs. However, there are different limitations inherent to the gastrointestinal region that produce variations in the bioavailability of drugs. The use of NP is desirable to ensure adequate bioavailability, drug stability, and even control in the sustained release system. The presence of non-ionic surfactants can increase mucus penetration, reduce recognition and clearance, enhance plasma circulation times, and promote drug accumulation. PEG is one of the predominant strategies, and it is also a passive mucopenetrating excipient that reduces interactions with luminal components and mucus in the gut [287].

\subsection{Intranasal}

Nasal administration is intended for local or systemic action. Some advantages of the nasal region include a large surface area, low enzymatic activity, vascularized subepithelial layer with direct passage to the systemic circulation, and evasion of the first-pass metabolism in the liver. On the other hand, some challenges include low membrane permeability of polar drugs and rapid clearance [288]. In this respect, non-ionic surfactants as absorption enhancers may play an important role. For example, poloxamer 188 gels promote the permeation of nanocubic vehicles and PLGA mixture-based DNA NP. Furthermore, an intentional comparative study to evaluate the effect of non-ionic surfactants on the intranasal permeation of sumatriptan succinate demonstrated that Laurate sucrose ester promoted higher absorption and absolute bioavailability. However, the effects of polyethoxylated castor oil (cremophor $\mathrm{EL}^{\circledR}$ ) and poloxamer 188 were also desirable [288]. 


\subsection{Pulmonary}

Pulmonary drug delivery allows local and systemic effects. The lung has advantages such as avoiding the gastrointestinal environment and reducing the first-pass metabolism of drugs. However, its main barriers in the absorption process are the epithelial and capillary cell barrier and a surfactant layer. Strategically, one of the tools in drug delivery is the decrease in particle size and surfactants at the interface [289]. In this regard, nonionic surfactants act as modifiers of the absorption of drugs in the lung. For example, the combination of PS- 80 and poloxamer 407 increased the lung area under the curve of itraconazole particles up to nine times through a wetting mechanism with the absence of pro-inflammatory components. A similar strategy utilized PEG and PVA to stabilize sebacic acid particles obtained by an emulsion method. Furthermore, poloxamer 188 can also be used to stabilize inhalable particles with the additional advantage to prevent the absorption of proteins and peptides that can be absorbed in the air-liquid interface of droplets and produce surface erosion [289].

\section{Quality by Design in the Choice of a Surfactant: The Royal Road}

The pharmaceutical industry is working hard to achieve robust and high-quality drug products. The $\mathrm{QbD}$, which the International Conference of Harmonisation of Technical Requirements for Registration of Pharmaceuticals for Human Use defines in the harmonized tripartite guideline for the pharmaceutical development Q8(R2) [290], is "a systematic approach to development that begins with predefined objectives and emphasizes product and process understanding and process control, based on sound science and quality risk management." The $\mathrm{QbD}$ has been extended to the systematic development of drug products by minimizing challenges, including a lack of consistency in quality and product robustness. The application of $\mathrm{QbD}$ to nanopharmaceutical products has several benefits for optimizing product performance in terms of complex design, dynamic material properties, and stringent regulatory requirements for quality attributes (QAs), including particle size, zeta potential, drug loading, in vitro drug release profile, surface morphology characteristics, pharmacokinetic performance, drug stability, and impurity profiling [291].

In the current Quality by Test $(\mathrm{QbT})$ system, product quality is ensured by following a sequence of steps, including raw material testing, fixed drug product manufacturing process, and end-product testing. If the specifications or other standards are met, the product may be kept in the manufacturing or incorporated into the market. Otherwise, it will have to be reprocessed [292]. Due to this situation, several compounds have been studied utilizing $\mathrm{QbD}$. The procedure for implementing $\mathrm{QbD}$ in the suspension of NP includes the following steps (Figure 5): (1) determine the stabilizers and preparation method according to the Quality Target Product Profile (QTPP), (2) define the Critical Quality Attributes (CQAs) (particle size, charge, stability, etc.) and from that to establish the critical material attributes (CMAs) and the Critical Process Parameters (CPPs) based on prior knowledge when conducting risk assessment, and (3) conduct Design of Experiments (DoE) to build a design space and verify its feasibility and robustness [293]. DoE is a better strategy than changing a single experimental factor and keeping other factors constant that can lead to more experiments than are feasible, especially if many variables are of concern. Furthermore, this eliminates the possibility of evaluating factor interactions [294]. From careful and systematic considerations, the industry and researchers can assess the influence of variables (for example, type and amount of stabilizer) on the nanoparticle CQAs, which helps achieve minimal particle size, good crystallinity, a high yield percentage, and more [295]. 


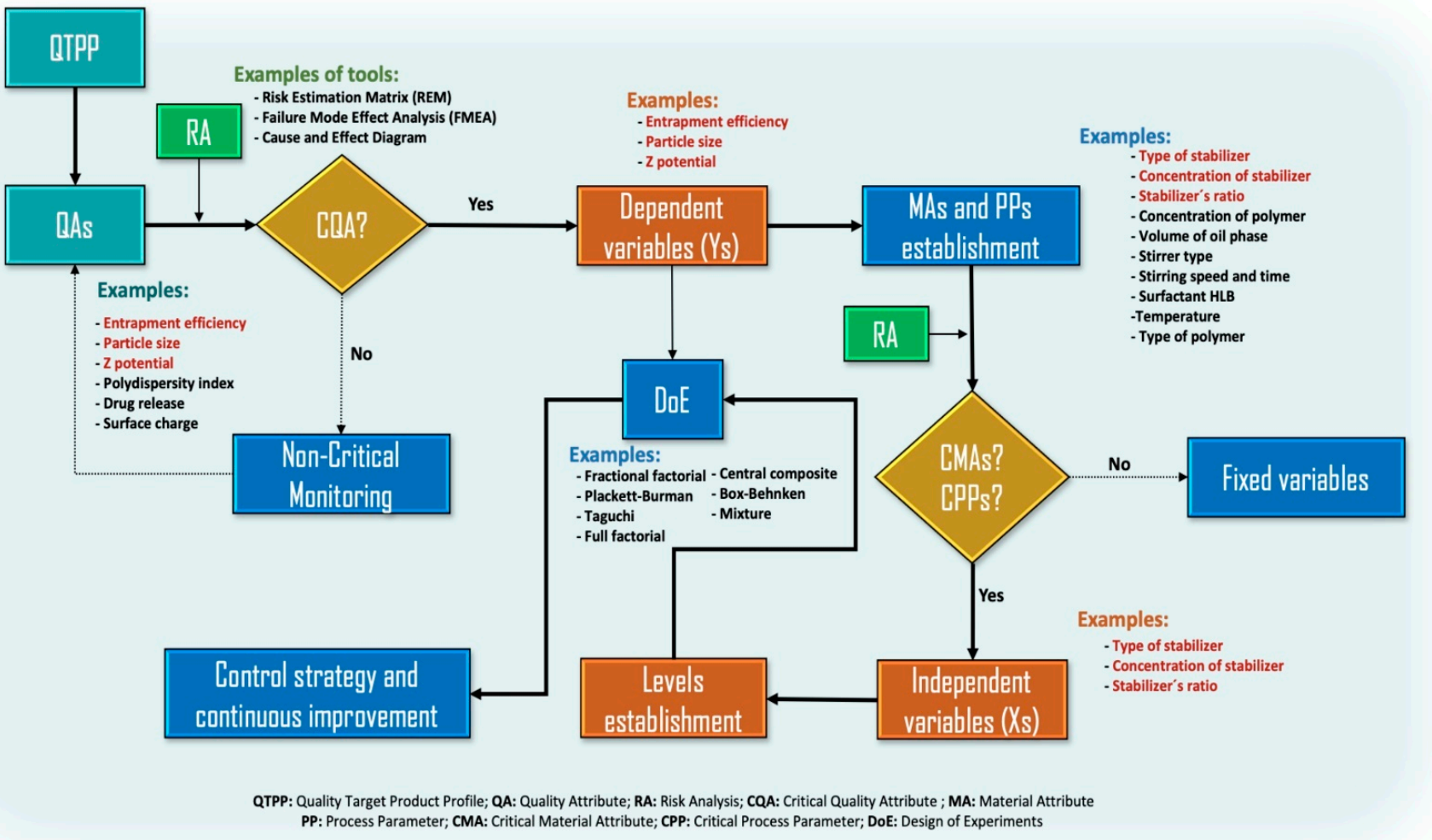

Figure 5. General steps for implementing QbD in the suspension of NP considering the variables related to or affected by surfactants as stabilizers.

Based on the above, it can be considered that the search for a successful nanoparticlebased product results from the effect of several variables. One of these variables is associated with the selection of the stabilizer since it has been shown in several studies that the stabilizer, which is generally a surfactant, has a significant impact on several response variables of the NP; for example, on the efficiency of encapsulation, particle size, charge, among others. Through the employment of QbD, Saha et al. [296] indicated that the encapsulation efficiency of resveratrol in mucoadhesive lecithin/chitosan NP for prolonged ocular drug delivery was significantly influenced by the concentration of poloxamer 407 and also revealed a significant interaction with the concentration of resveratrol utilized in the manufacture of their NP. The evaluation of the effect of poloxamer 407 was established after a risk analysis in which the polymer, together with the lecithin concentration, chitosan to lecithin ratio, and drug concentration, were categorized by the severity score as high-risk material attributes. The poloxamer 407 was ranked with a higher risk score than other concerning parameters of the manufacturing process, such as the molecular weight of chitosan, lecithin grade, type of needle, stirring speed, and injection rate others. Moreover, parameters such as particle size, $Z$ potential, encapsulation efficiency, and drug release were considered QAs of greater relevance.

On the other hand, Patel et al. [297] evaluated the effect of the type of surfactant (poloxamer 188 and PS-80) and concentration (0.5\%, 2.0\%, and 5.0\%) on the development of topical arginine solid lipid NP (SLN) from a QbD approach. After a risk analysis, the authors found that the surfactant concentration presented a higher risk priority number (RPN) than some process parameters such as homogenization speed and time, sonication time and amplitude, and temperature. The study established that poloxamer 188 had a more pronounced effect on particle size and drug loading percentage than poloxamer 407 and PS-80 alone.

With the above, we can see that three of the most common CMAs in the evaluation by $\mathrm{QbD}$ concerning the stabilization of NP are the concentration of surfactant, the type of sur- 
factant, and the surfactant ratio (Figure 6). Of the three above, the surfactant concentration turns out to be the one that has been most studied in the development of NP, as shown by the review made by Cunha et al. [298]. The authors indicated that the independent variables (CMAs) of lipid(s) and emulsifier(s) concentration produced important effects on the dependent variables (CQAs), mainly in SLN and nanostructured lipid carriers (NLC). However, it has also been observed that the temperature of the stabilizer solution may impact the size and size distribution of dispersion [299], so it can also be considered within the risk analysis to choose the CPPs.

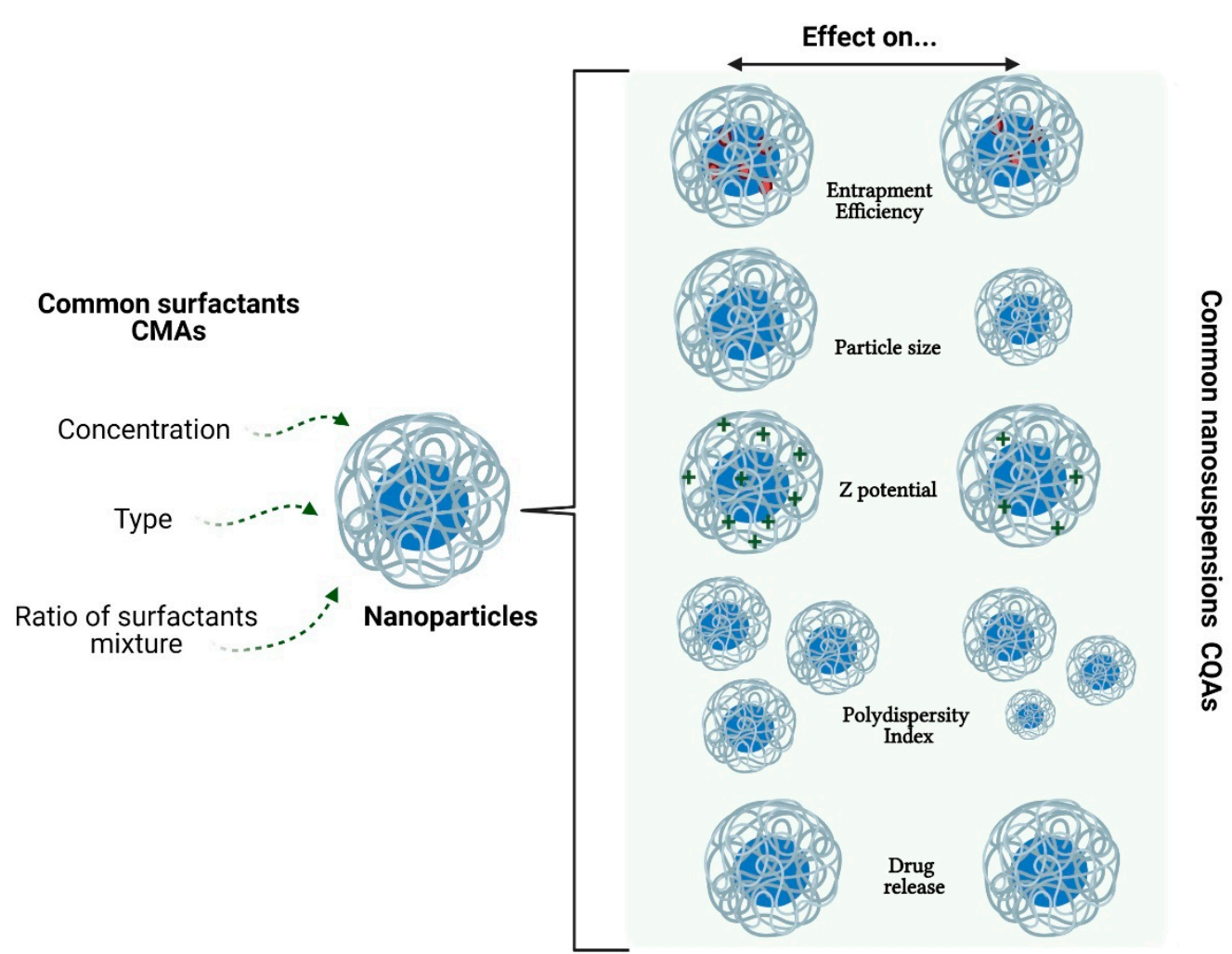

Figure 6. Common CQAs are affected by the most common CMAs of the surfactants.

As mentioned, the establishment of CMAs related to NP stabilizers is carried out through risk analysis. The risk analysis to identify and evaluate the type and concentration of the stabilizer as CMAs, during the manufacture of NP, has been carried out mainly through strategies such as Cause and Effect Diagram [300], Failure Mode Effects Analysis (FMEA) [301] and Risk Estimation Matrix (REM) [302]. Despite proving certain differences, all strategies lead to categorizing both variables as critical impacting on CQAs: particle size, zeta potential, entrapment efficiency, PDI, and amount of drug released. However, other tools such as Failure Mode, Effects, and Criticality Analysis (FMECA), Fault Tree Analysis (FTA), Hazard Analysis and Critical Control Points (HACCP), Hazard Operability Analysis (HAZOP), and Preliminary Hazard Analysis (PHA) [209] can also be implemented.

\section{Drawbacks and Future}

As described in previous sections, the diversity of surfactant types is vast, and the possibility of derivatization towards new applications is also possible. It is one of the trends in the search for environmentally friendly surfactants. We detected that although there are different innovations in new structures, there is a predominance of the three mentioned stabilizers, PS, PVA, and poloxamers. However, there is not a complete description of the stabilizer properties in most studies in the case of PVA; while with the PS, some aspects persist about the possible toxic effect in biological models. Concerning poloxamers, the trade names for Lutrol ${ }^{\circledR}$ and Pluronic ${ }^{\circledR}$ make it challenging to distinguish structurally 
from the type of stabilizer. The new trends outline the lines of research in the search for surfactants of natural origin that allow a high interaction in the interfaces but with high biocompatibility and biodegradation. There may even be modifications of naturally occurring surfactants with synthetic surfactant fragments.

\section{Conclusions}

Non-ionic surfactants offer a wide versatility of applications in the different manufacturing methods of polymeric nanoparticles, highlighting their high biocompatibility and moderate interaction with biological barriers. Reports of significant toxicity are scarce, while the physicochemical parameters of nanoparticles are widely modulated, from particle size to encapsulation capacity. Although some PS, PVA, and poloxamers derivatives exist, the traditional use of primary structures predominates due to the high stability conferred to dispersed systems. The stability-biointeraction balance is necessary to have an adequate performance of the formulation. At the same time, the systematic approach of $\mathrm{QbD}$ in the choice of a surfactant is a route that has marked for some years a new and reliable experimental strategy. The outlook in the manufacture of polymeric nanoparticles for biomedical applications seems to indicate that the use of non-ionic surfactants will continue to predominate in the following years due to their ease of application, broad utility, and extensive biosafety background.

Author Contributions: Conceptualization, H.C., M.L.D.P.-A., J.J.M. and G.L.-G.; investigation, H.H.P., S.A.B.-C., M.L.D.P.-A., I.H.C.-F., F.V.B.-J., M.G.-T. and G.L.-G.; writing-original draft preparation, H.C., H.H.-P., S.A.B.-C., M.L.D.P.-A., I.H.C.-F., F.V.B.-J., M.G.-T. and G.L.-G.; writing-review and editing, J.J.M. and G.L.-G.; visualization, G.L.-G.; supervision, G.L.-G.; project administration, J.J.M. and G.L.-G. All authors have read and agreed to the published version of the manuscript.

Funding: This research was funded by a CONACYT grant (grant number 258043) and Fundación Miguel Alemán Valdés grant to Jonathan J. Magaña, and by CONACYT grant (CB A1-S-15759) to Gerardo Leyva-Gómez.

Institutional Review Board Statement: Not applicable.

Informed Consent Statement: Not applicable.

Data Availability Statement: Data is contained within the article.

Acknowledgments: The authors thank www.Biorender.com for the figures created.

Conflicts of Interest: The authors declare no conflict of interest.

\section{References}

1. Suhail, M.; Janakiraman, A.K.; Khan, A.; Naeem, A.; Badshah, S.F. Surfactants and their role in pharmaceutical product de-velopment: An overview. J. Pharm. Pharm. 2019, 6, 72-82.

2. Strickley, R.G. Solubilizing excipients used in commercially available oral and injectable formulations. Pharm. Res. 2004, 21, 201-230. [CrossRef] [PubMed]

3. Joshi, T. A short history and preamble of surfactants. Int. J. Appl. Chem. 2017, 13, 283-292.

4. Phan, H.T.; Haes, A.J. What does nanoparticle stability mean? J. Phys. Chem. C 2019, 123, 16495-16507. [CrossRef]

5. Cheraghian, G. Evaluation of clay and fumed silica nanoparticles on adsorption of surfactant polymer during enhanced oil recovery. J. Japan Pet. Inst. 2017, 60, 85-94. [CrossRef]

6. Tapia-Guerrero, Y.S.; Del Prado-Audelo, M.L.; Borbolla-Jiménez, F.V.; Giraldo Gomez, D.M.; García-Aguirre, I.; Colín-Castro, C.A.; Morales-González, J.A.; Leyva-Gómez, G.; Magaña, J.J. Effect of UV and gamma irradiation sterilization processes in the properties of different polymeric nanoparticles for biomedical applications. Materials 2020, 13, 1090. [CrossRef]

7. Kulkarni, S.A.; Feng, S.S. Effects of particle size and surface modification on cellular uptake and biodistribution of polymeric nanoparticles for drug delivery. Pharm. Res. 2013, 30, 2512-2522. [CrossRef]

8. Salatin, S.; Maleki Dizaj, S.; Yari Khosroushahi, A. Effect of the surface modification, size, and shape on cellular uptake of nanoparticles. Cell Biol. Int. 2015, 39, 881-890. [CrossRef]

9. Khandelwal, P.; Das, A.; Sen, C.K.; Srinivas, S.P.; Roy, S.; Khanna, S. A surfactant polymer wound dressing protects human keratinocytes from inducible necroptosis. Sci. Rep. 2021, 11, 1-15. [CrossRef]

10. Piva, S.; DiBlasi, R.M.; Slee, A.E.; Jobe, A.H.; Roccaro, A.M.; Filippini, M.; Latronico, N.; Bertoni, M.; Marshall, J.C.; Portman, M.A. Surfactant therapy for COVID-19 related ARDS: A retrospective case-control pilot study. Respir. Res. 2021, 22, 1-8. [CrossRef] 
11. De Luca, D.; Cogo, P.; Kneyber, M.C.; Biban, P.; Semple, M.G.; Perez-Gil, J.; Conti, G.; Tissieres, P.; Rimensberger, P.C. Surfactant therapies for pediatric and neonatal ARDS: ESPNIC expert consensus opinion for future research steps. Crit. Care 2021, 25, 1-12. [CrossRef] [PubMed]

12. Wilson, B.; Selvam, J.; Mukundan, G.K.; Premakumari, K.B.; Jenita, J.L. Albumin nanoparticles coated with polysorbate 80 for the targeted delivery of antiepileptic drug levetiracetam into the brain. Drug Deliv. Transl. Res. 2020, 10, 1853-1861. [CrossRef] [PubMed]

13. Chintamaneni, P.K.; Krishnamurthy, P.T.; Pindiprolu, S.K.S.S. Polysorbate- 80 surface modified nano-stearylamine BQCA conjugate for the management of Alzheimer's disease. RSC Adv. 2021, 11, 5325-5334. [CrossRef]

14. Yusuf, M.; Khan, M.; Alrobaian, M.M.; Alghamdi, S.A.; Warsi, M.H.; Sultana, S.; Khan, R.A. Brain targeted Polysorbate-80 coated PLGA thymoquinone nanoparticles for the treatment of Alzheimer's disease, with biomechanistic insights. J. Drug Deliv. Sci. Technol. 2021, 61, 102214. [CrossRef]

15. Shaban, S.M.; Kang, J.; Kim, D.H. Surfactants: Recent advances and their applications. Compos. Commun. 2020, $22,100537$. [CrossRef]

16. Hotze, E.M.; Phenrat, T.; Lowry, G.V. Nanoparticle aggregation: Challenges to understanding transport and reactivity in the environment. J. Environ. Qual. 2010, 39, 1909-1924. [CrossRef] [PubMed]

17. Heinz, H.; Pramanik, C.; Heinz, O.; Ding, Y.; Mishra, R.K.; Marchon, D.; Flatt, R.J.; Estrela-Lopis, I.; Llop, J.; Moya, S.; et al. Nanoparticle decoration with surfactants: Molecular interactions, assembly, and applications. Surf. Sci. Rep. 2017, 72, 1-58. [CrossRef]

18. Voigt, N.; Henrich-Noack, P.; Kockentiedt, S.; Hintz, W.; Tomas, J.; Sabel, B.A. Surfactants, not size or zeta-potential influence blood-brain barrier passage of polymeric nanoparticles. Eur. J. Pharm. Biopharm. 2014, 87, 19-29. [CrossRef]

19. Kogawa, A.C.; Cernic, B.G.; do Couto, L.G.D.; Salgado, H.R.N. Synthetic detergents: 100 years of history. Saudi Pharm. J. 2017, 25, 934-938. [CrossRef]

20. Myers, E.G. Soap and Detergents. In Inedible Meat By-Products; Springer: Berlin/Heidelberg, Germany, $1992 ;$ pp. $149-176$.

21. Lagaly, G.; Weiss, A. Anordnung und Orientierung kationischer Tenside auf Silicatoberflächen—II. Paraffinähnliche Strukturen bei den n-Alkylammonium-Schichtsilicaten mit hoher Schichtladung (Glimmer). Kolloid-Zeitschrift Zeitschrift für Polymere 1970, 237, 364-368. [CrossRef]

22. Meyer, R.A.; Green, J.J. Shaping the future of nanomedicine: Anisotropy in polymeric nanoparticle design. Wiley Interdiscip. Rev. Nanomed. Nanobiotechnology 2016, 8, 191-207. [CrossRef]

23. Wu, L.; Zhang, J.; Watanabe, W. Physical and chemical stability of drug nanoparticles. Adv. Drug Deliv. Rev. 2011, 63, 456-469. [CrossRef]

24. Trefalt, G.; Montes Ruiz-Cabello, F.J.; Borkovec, M. Interaction forces, heteroaggregation, and deposition involving charged colloidal particles. J. Phys. Chem. B 2014, 118, 6346-6355. [CrossRef]

25. Pazmino, E.; Trauscht, J.; Dame, B.; Johnson, W.P. Power law size-distributed heterogeneity explains colloid retention on soda lime glass in the presence of energy barriers. Langmuir 2014, 30, 5412-5421. [CrossRef]

26. Sun, H.; Jiao, R.; An, G.; Xu, H.; Wang, D.; Lee, D.J. Influence of particle size on the aggregation behavior of nanoparticles: Role of structural hydration layer. J. Environ. Sci. 2021, 103, 33-42. [CrossRef] [PubMed]

27. Arab, D.; Kantzas, A.; Bryant, S.L. Nanoparticle stabilized oil in water emulsions: A critical review. J. Pet. Sci. Eng. 2018, 163, 217-242. [CrossRef]

28. Leyva-Gómez, G.; Cortés, H.; Magaña, J.J.; Leyva-García, N.; Quintanar-Guerrero, D.; Florán, B. Nanoparticle technology for treatment of Parkinson's disease: The role of surface phenomena in reaching the brain. Drug Discov. Today 2015, 20, 824-837. [CrossRef]

29. Bhakay, A.; Rahman, M.; Dave, R.N.; Bilgili, E. Bioavailability enhancement of poorly water-soluble drugs via nanocomposites: Formulation-Processing aspects and challenges. Pharmaceutics 2018, 10, 86. [CrossRef] [PubMed]

30. Bilgili, E.; Li, M.; Afolabi, A. Is the combination of cellulosic polymers and anionic surfactants a good strategy for ensuring physical stability of BCS Class II drug nanosuspensions? Pharm. Dev. Technol. 2016, 21, 499-510. [CrossRef]

31. Anestopoulos, I.; Kiousi, D.E.; Klavaris, A.; Galanis, A.; Salek, K.; Euston, S.R.; Pappa, A.; Panayiotidis, M.I. Surface active agents and their health-promoting properties: Molecules of multifunctional significance. Pharmaceutics 2020, 12, 688. [CrossRef]

32. Rapp, B.E. Surface Tension. In Microfluidics: Modelling, Mechanics and Mathematics; Elsevier: Amsterdam, The Netherlands, 2017; pp. 421-444.

33. Clendennen, S.K.; Boaz, N.W. Betaine Amphoteric Surfactants-Synthesis, Properties, and Applications. In Biobased Surfactants; AOCS Press: Urbana, IL, USA, 2019; pp. 447-469.

34. Afra, S.; Samouei, H.; Truong, P.; Nasr-El-Din, H. Micellar growth and network formation in acidic solutions of a sulfobetaine zwitterionic surfactant triggered by an inorganic salt. Soft Matter 2020, 16, 4494-4501. [CrossRef] [PubMed]

35. Lin, W.; Kampf, N.; Klein, J. Designer Nanoparticles as Robust Superlubrication Vectors. ACS Nano 2020, 14, 7008-7017. [CrossRef] [PubMed]

36. Sekhon, B.S. Surfactants: Pharmaceutical and Medicinal Aspects. J. Pharm. Technol. Res. Manag. 2013, 1, 43-68. [CrossRef]

37. Zakharova, L.Y.; Pashirova, T.N.; Doktorovova, S.; Fernandes, A.R.; Sanchez-Lopez, E.; Silva, A.M.; Souto, S.B.; Souto, E.B. Cationic surfactants: Self-assembly, structure-activity correlation and their biological applications. Int. J. Mol. Sci. 2019, 20, 5534. [CrossRef] [PubMed] 
38. Benhur, A.M.; Diaz, J.; Amin, S. Impact of polyelectrolyte-surfactant interactions on the rheology and wet lubrication performance of conditioning shampoo. Int. J. Cosmet. Sci. 2021, 43, 246-253. [CrossRef]

39. Smułek, W.; Burlaga, N.; Hricovíni, M.; Medved'ová, A.; Kaczorek, E.; Hricovíniová, Z. Evaluation of surface active and antimicrobial properties of alkyl D-lyxosides and alkyl L-rhamnosides as green surfactants. Chemosphere 2021, $271,129818$. [CrossRef]

40. Keck, C.M.; Kovačević, A.; Müller, R.H.; Savić, S.; Vuleta, G.; Milić, J. Formulation of solid lipid nanoparticles (SLN): The value of different alkyl polyglucoside surfactants. Int. J. Pharm. 2014, 474, 33-41. [CrossRef]

41. Souza, F.D.; Souza, B.S.; Tondo, D.W.; Leopoldino, E.C.; Fiedler, H.D.; Nome, F. Imidazolium-based zwitterionic surfactants: Characterization of normal and reverse micelles and stabilization of nanoparticles. Langmuir 2015, 31, 3587-3595. [CrossRef]

42. Kovačević, A.B.; Müller, R.H.; Savić, S.D.; Vuleta, G.M.; Keck, C.M. Solid lipid nanoparticles (SLN) stabilized with polyhydroxy surfactants: Preparation, characterization and physical stability investigation. Colloids Surf. A Physicochem. Eng. Asp. 2014, 444, 15-25. [CrossRef]

43. Voulgaridou, G.P.; Mantso, T.; Anestopoulos, I.; Klavaris, A.; Katzastra, C.; Kiousi, D.E.; Mantela, M.; Galanis, A.; Gardikis, K.; Banat, I.M.; et al. Toxicity profiling of biosurfactants produced by novel marine bacterial strains. Int. J. Mol. Sci. 2021, $22,2383$. [CrossRef]

44. Sanjivkumar, M.; Deivakumari, M.; Immanuel, G. Investigation on spectral and biomedical characterization of rhamnolipid from a marine associated bacterium Pseudomonas aeruginosa (DKB1). Arch. Microbiol. 2021. [CrossRef]

45. Razafindralambo, H. Carbohydrate-Based Surfactants: Structure-Activity Relationships; Blecker, C., Ed.; IntechOpen: Rijeka, Croatia, 2012; pp. 215-228.

46. Charoensit, P.; Pompimon, W.; Khorana, N.; Sungthongjeen, S. Effect of amide linkage of PEG-lipid conjugates on the stability and cytotoxic activity of goniodiol loaded in PEGylated liposomes. J. Drug Deliv. Sci. Technol. 2019, 50, 1-8. [CrossRef]

47. Su, Y.; Tang, W.; Song, Y.; Wang, C.; Tian, Q.; Wang, X.; Quan, J.; Li, B.; Wang, S.; Deng, Y. Mixed PEGylated surfactant modifying system decrease the accelerated blood clearance phenomenon of nanoemulsions in rats. Asian J. Pharm. Sci. 2017, 12, 28-36. [CrossRef] [PubMed]

48. Summary of the Public Assessment Report for Pfizer/BioNTech COVID-19 Vaccine. Available online: https://www.gov.uk/ government/publications / regulatory-approval-of-pfizer-biontech-vaccine-for-covid-19/summary-public-assessment-reportfor-pfizerbiontech-covid-19-vaccine (accessed on 23 May 2021).

49. Polack, F.P.; Thomas, S.J.; Kitchin, N.; Absalon, J.; Gurtman, A.; Lockhart, S.; Perez, J.L.; Pérez Marc, G.; Moreira, E.D.; Zerbini, C.; et al. Safety and Efficacy of the BNT162b2 mRNA Covid-19 Vaccine. N. Engl. J. Med. 2020, 383, 2603-2615. [CrossRef] [PubMed]

50. Hofman, K.; Shenoy, G.N.; Chak, V.; Balu-Iyer, S.V. Pharmaceutical Aspects and Clinical Evaluation of COVID-19 Vaccines. Immunol. Investig. 2021, 0, 1-37. [CrossRef]

51. Devalapally, H.; Duan, Z.; Seiden, M.V.; Amiji, M.M. Paclitaxel and ceramide co-administration in biodegradable polymeric nanoparticulate delivery system to overcome drug resistance in ovarian cancer. Int. J. Cancer 2007, 121, 1830-1838. [CrossRef]

52. Chevalier, Y.; Bolzinger, M.A. Emulsions stabilized with solid nanoparticles: Pickering emulsions. Colloids Surf. A Physicochem. Eng. Asp. 2013, 439, 23-34. [CrossRef]

53. Pickering, S.U. CXCVI.-Emulsions. J. Chem. Soc. Trans. 1907, 91, 2001-2021. [CrossRef]

54. Robin, B.; Albert, C.; Beladjine, M.; Legrand, F.-X.; Geiger, S.; Moine, L.; Nicolas, V.; Canette, A.; Trichet, M.; Tsapis, N.; et al. Tuning morphology of Pickering emulsions stabilised by biodegradable PLGA nanoparticles: How PLGA characteristics influence emulsion properties. J. Colloid Interface Sci. 2021, 595. [CrossRef]

55. Food Safety Commission. Evaluation Report of Food Additives Polysorbates (Polysorbates 20, 60, 65 and 80); Food Safety Commission: Tokyo, Japan, 2007.

56. Martos, A.; Koch, W.; Jiskoot, W.; Wuchner, K.; Winter, G.; Friess, W.; Hawe, A. Trends on analytical characterization of polysorbates and their degradation products in biopharmaceutical formulations. J. Pharm. Sci. 2017, 106, 1722-1735. [CrossRef]

57. Kishore, R.S.K.; Kiese, S.; Fischer, S.; Pappenberger, A.; Grauschopf, U.; Mahler, H.C. The degradation of polysorbates 20 and 80 and its potential impact on the stability of biotherapeutics. Pharm. Res. 2011, 28, 1194-1210. [CrossRef] [PubMed]

58. Kerwin, B.A. Polysorbates 20 and 80 used in the formulation of protein biotherapeutics: Structure and degradation pathways J. Pharm. Sci. 2008, 97, 2924-2935. [CrossRef]

59. Moore, J. Final Report on the Safety Assessment of Polysorbates 20, 21, 40, 60, 61, 65, 80, 81, and 85. J. Am. Coll. Toxicol. 1984, 3 , 1-82.

60. Hoda, M.; Pajaniradje, S.; Shakya, G.; Mohankumar, K.; Rajagopalan, R. Anti-proliferative and apoptosis-triggering potential of disulfiram and disulfiram-loaded polysorbate 80-stabilized PLGA nanoparticles on hepatocellular carcinoma Hep3B cell line. Nanomed. Nanotechnol. Biol. Med. 2016, 12, 1641-1650. [CrossRef]

61. Sinha, N.; Joshi, A.S.; Thakur, A.K. Analytical validation of an ATR-FTIR based method for quantifying the amount of polysorbate 80 adsorbed on PLGA nanoparticles. Anal. Methods 2020, 12, 5360-5366. [CrossRef]

62. Katiyar, S.S.; Muntimadugu, E.; Rafeeqi, T.A.; Domb, A.J.; Khan, W. Co-delivery of rapamycin- and piperine-loaded polymeric nanoparticles for breast cancer treatment. Drug Deliv. 2016, 23, 2608-2616. [CrossRef]

63. Onyema, H.N.; Berger, M.; Musyanovych, A.; Bantz, C.; Maskos, M.; Freese, C. Uptake of polymeric nanoparticles in a human induced pluripotent stem cell-based blood-brain barrier model: Impact of size, material, and protein corona. Biointerphases 2021, 16, 021004. [CrossRef] 
64. Nguyen, H.T.; Tran, T.H.; Kim, J.O.; Yong, C.S.; Nguyen, C.N. Enhancing the in vitro anti-cancer efficacy of artesunate by loading into poly-D,L-lactide-co-glycolide (PLGA) nanoparticles. Arch. Pharm. Res. 2015, 38, 716-724. [CrossRef] [PubMed]

65. Jose, S.; Sowmya, S.; Cinu, T.A.; Aleykutty, N.A.; Thomas, S.; Souto, E.B. Surface modified PLGA nanoparticles for brain targeting of Bacoside-A. Eur. J. Pharm. Sci. 2014, 63, 29-35. [CrossRef] [PubMed]

66. Tahara, K.; Yamamoto, H.; Kawashima, Y. Cellular uptake mechanisms and intracellular distributions of polysorbate 80-modified poly (D,L-lactide-co-glycolide) nanospheres for gene delivery. Eur. J. Pharm. Biopharm. 2010, 75, 218-224. [CrossRef] [PubMed]

67. Yuan, X.; Ji, W.; Chen, S.; Bao, Y.; Tan, S.; Lu, S.; Wu, K.; Chu, Q. Anovel paclitaxel-loaded poly(D,L-lactide-co-glycolide)-Tween 80 copolymer nanoparticle overcoming multidrug resistance for lung cancer treatment. Int. J. Nanomed. 2016, 11, $2119-2131$.

68. Xu, R.; Wang, J.; Xu, J.; Song, X.; Huang, H.; Feng, Y.; Fu, C. Rhynchophylline loaded-mPEG-PLGA nanoparticles coated with tween-80 for preliminary study in Alzheimer's disease. Int. J. Nanomed. 2020, 15, 1149-1160. [CrossRef] [PubMed]

69. Das, D.; Lin, S. Double-coated poly (butylcynanoacrylate) nanoparticulate delivery systems for brain targeting of dalargin via oral administration. J. Pharm. Sci. 2005, 94, 1343-1353. [CrossRef] [PubMed]

70. Al-Kassas, R.; Madni, A.; Buchanan, C.; Shelling, A.N. pH-Sensitive Nanoparticles Developed and Optimized Using Factorial Design for Oral Delivery of Gliclazide. J. Pharm. Innov. 2021. [CrossRef]

71. Neibloom, D.; Bevan, M.A.; Frechette, J. Surfactant-Stabilized Spontaneous 3-(Trimethoxysilyl) Propyl Methacrylate Nanoemulsions. Langmuir 2020, 36, 284-292. [CrossRef] [PubMed]

72. Mahmoudi, M.; Saeidian, H.; Mirjafary, Z.; Mokhtari, J. Preparation and characterization of memantine loaded polycaprolactone nanocapsules for Alzheimer's disease. J. Porous Mater. 2021, 28, 205-212. [CrossRef]

73. Ahsaei, S.M.; Talebi-Jahromi, K.; Amoabediny, G. Insecticidal activity of polycaprolactone nanoparticles decorated with chitosan containing two essential oils against Tribolium confusum. Int. J. Pest Manag. 2020, 1, 1-9. [CrossRef]

74. Badri, W.; Miladi, K.; Nazari, Q.A.; Fessi, H.; Elaissari, A. Effect of process and formulation parameters on polycaprolactone nanoparticles prepared by solvent displacement. Colloids Surf. A Physicochem. Eng. Asp. 2017, 516, 238-244. [CrossRef]

75. Elmowafy, M.; Alruwaili, N.K.; Shalaby, K.; Alharbi, K.S.; Altowayan, W.M.; Ahmed, N.; Zafar, A.; Elkomy, M. Long-acting paliperidone parenteral formulations based on polycaprolactone nanoparticles; the influence of stabilizer and chitosan on in vitro release, protein adsorption, and cytotoxicity. Pharmaceutics 2020, 12, 160. [CrossRef]

76. Amrite, A.C.; Edelhauser, H.F.; Singh, S.R.; Kompella, U.B. Effect of circulation on the disposition and ocular tissue distribution of $20 \mathrm{~nm}$ nanoparticles after periocular administration. Mol. Vis. 2008, 14, 150-160.

77. Fu, J.; Wu, C. Laser light scattering study of the degradation of poly(sebacic anhydride) nanoparticles. J. Polym. Sci. Part B Polym. Phys. 2001, 39, 703-708. [CrossRef]

78. Shakeri, F.; Shakeri, S.; Hojjatoleslami, M. Preparation and characterization of carvacrol loaded polyhydroxybutyrate nanoparticles by nanoprecipitation and dialysis methods. J. Food Sci. 2014, 79, N697-N705. [CrossRef]

79. Sukmawati, A.; Utami, W.; Yuliani, R.; Da'I, M.; Nafarin, A. Effect of tween 80 on nanoparticle preparation of modified chitosan for targeted delivery of combination doxorubicin and curcumin analogue. IOP Conf. Ser. Mater. Sci. Eng. 2018, $311,012024$. [CrossRef]

80. Talib, S.; Ahmed, N.; Khan, D.; Khan, G.M.; Rehman, A. Ur Chitosan-chondroitin based artemether loaded nanoparticles for transdermal drug delivery system. J. Drug Deliv. Sci. Technol. 2021, 61, 102281. [CrossRef]

81. Bhattacharya, S. Fabrication and characterization of chitosan-based polymeric nanoparticles of Imatinib for colorectal cancer targeting application. Int. J. Biol. Macromol. 2020, 151, 104-115. [CrossRef]

82. Govindaraju, R.; Karki, R.; Chandrashekarappa, J.; Santhanam, M.; Shankar, A.K.K.; Joshi, H.K.; Divakar, G. Enhanced Water Dispersibility of Curcumin Encapsulated in Alginate-Polysorbate 80 Nano Particles and Bioavailability in Healthy Human Volunteers. Pharm. Nanotechnol. 2019, 7, 39-56. [CrossRef]

83. Masotti, A.; Vicennati, P.; Alisi, A.; Marianecci, C.; Rinaldi, F.; Carafa, M.; Ortaggi, G. Novel Tween ${ }^{\circledR 2} 2$ derivatives enable the formation of efficient $\mathrm{pH}$-sensitive drug delivery vehicles for human hepatoblastoma. Bioorganic Med. Chem. Lett. 2010, 20, 3021-3025. [CrossRef] [PubMed]

84. Hartl, N.; Adams, F.; Merkel, O.M. From adsorption to covalent bonding: Apolipoprotein E functionalization of polymeric nanoparticles for drug delivery across the blood-brain barrier. Adv. Ther. 2021, 4, 1-21. [CrossRef]

85. Kreuter, J.; Ramge, P.; Petrov, V.; Hamm, S.; Gelperina, S.E.; Engelhardt, B.; Alyautdin, R.; Von, H.; Begley, D.J. Direct evidence that poly (butylcyanoacrylate) nanoparticles deliver drugs to the CNS via specific mechanisms requiring prior binding of drug to the nanoparticles. Pharm. Res. 2003, 20, 409-416. [CrossRef] [PubMed]

86. Sun, W.; Xie, C.; Wang, H.; Hu, Y. Specific role of polysorbate 80 coating on the targeting of nanoparticles to the brain. Biomaterials 2004, 25, 3065-3071. [CrossRef]

87. Ravichandran, V.; Nguyen Cao, T.G.; Choi, D.G.; Kang, H.C.; Shim, M.S. Non-ionic polysorbate-based nanoparticles for efficient combination chemo/photothermal/photodynamic therapy. J. Ind. Eng. Chem. 2020, 88, 260-267. [CrossRef]

88. National Center for Biotechnology Information. PubChem Compound Summary for CID 443314, Polysorbate 20. 2021. Available online: https:/ / pubchem.ncbi.nlm.nih.gov/compound/Polysorbate-20 (accessed on 27 April 2021).

89. Chang, J.; Jallouli, Y.; Kroubi, M.; Yuan, X.; Feng, W.; Kang, C.; Pu, P.; Betbeder, D. Characterization of endocytosis of transferrincoated PLGA nanoparticles by the blood-brain barrier. Int. J. Pharm. 2009, 379, 285-292. [CrossRef] [PubMed]

90. Coors, E.A.; Seybold, H.; Merk, H.F.; Mahler, V. Polysorbate 80 in medical products and nonimmunologic anaphylactoid reactions. Ann. Allergy Asthma Immunol. 2005, 95, 593-599. [CrossRef] 
91. Schwartzberg, L.S.; Navari, R.M. Safety of Polysorbate 80 in the Oncology Setting. Adv. Ther. 2018, 35, 754-767. [CrossRef] [PubMed]

92. Helgason, T.; Awad, T.S.; Kristbergsson, K.; McClements, D.J.; Weiss, J. Effect of surfactant surface coverage on formation of solid lipid nanoparticles (SLN). J. Colloid Interface Sci. 2009, 334, 75-81. [CrossRef]

93. Grabarek, A.D.; Bozic, U.; Rousel, J.; Menzen, T.; Kranz, W.; Wuchner, K.; Jiskoot, W.; Hawe, A. What Makes Polysorbate Functional? Impact of Polysorbate 80 Grade and Quality on IgG Stability During Mechanical Stress. J. Pharm. Sci. 2020, 109, 871-880. [CrossRef] [PubMed]

94. Alade, O.S.; Al Shehri, D.; Mahmoud, M.; Mokheimer, E.M.A.; Al Hamad, J.; Kamal, M.S.; Al-Nakhli, A.; Sasaki, K. A novel technique for heavy oil recovery using poly vinyl alcohol (PVA) and PVA-NaOH with ethanol additive. Fuel 2021, 285, 119128. [CrossRef]

95. Park, M.J.; Gonzales, R.R.; Abdel-Wahab, A.; Phuntsho, S.; Shon, H.K. Hydrophilic polyvinyl alcohol coating on hydrophobic electrospun nanofiber membrane for high performance thin film composite forward osmosis membrane. Desalination 2018, 426, 50-59. [CrossRef]

96. Hago, E.E.; Li, X. Interpenetrating polymer network hydrogels based on gelatin and PVA by biocompatible approaches: Synthesis and characterization. Adv. Mater. Sci. Eng. 2013, 2013, 328763. [CrossRef]

97. Zarekhalili, Z.; Bahrami, S.H.; Ranjbar-Mohammadi, M.; Milan, P.B. Fabrication and characterization of PVA/Gum tragacanth/PCL hybrid nanofibrous scaffolds for skin substitutes. Int. J. Biol. Macromol. 2017, 94, 679-690. [CrossRef]

98. Scholes, P.D.; Coombes, A.G.A.; Illum, L.; Daviz, S.S.; Vert, M.; Davies, M.C. The preparation of sub-200 nm poly(lactide-coglycolide) microspheres for site-specific drug delivery. J. Control. Release 1993, 25, 145-153. [CrossRef]

99. Zambaux, M.F.; Bonneaux, F.; Gref, R.; Maincent, P.; Dellacherie, E.; Alonso, M.J.; Labrude, P.; Vigneron, C. Influence of experimental parameters on the characteristics of poly(lactic acid) nanoparticles prepared by a double emulsion method. J. Control. Release 1998, 50, 31-40. [CrossRef]

100. Carrio, A.; Schwach, G.; Coudane, J.; Vert, M. Preparation and degradation of surfactant-free PLAGA microspheres. J. Control. Release 1995, 37, 113-121. [CrossRef]

101. Hallensleben, M.L. Polyvinyl Compounds, Others. In Ullmann's Encyclopedia of Industrial Chemistry; Wiley-VCH: Weinheim, Germany, 2000; pp. 1-23.

102. Kawai, F.; Hu, X. Biochemistry of microbial polyvinyl alcohol degradation. Appl. Microbiol. Biotechnol. 2009, 84, 227-237. [CrossRef]

103. C Haweel, S.A. Preparation of polyvinyl alcohol from local raw material. Iraqi J. Chem. Pet. Eng. 2008, 9, 15-21.

104. Shahbazi, M.; Rajabzadeh, G.; Rafe, A.; Ettelaie, R.; Ahmadi, S.J. The physico-mechanical and structural characteristics of blend film of poly (vinyl alcohol) with biodegradable polymers as affected by disorder-to-order conformational transition. Food Hydrocoll. 2016, 60, 393-404. [CrossRef]

105. Chiellini, E.; Corti, A.; D’Antone, S.; Solaro, R. Biodegradation of poly (vinyl alcohol) based materials. Prog. Polym. Sci. 2003, 28, 963-1014. [CrossRef]

106. Baker, M.I.; Walsh, S.P.; Schwartz, Z.; Boyan, B.D. A review of polyvinyl alcohol and its uses in cartilage and orthopedic applications. J. Biomed. Mater. Res. 2012, 100, 1451-1457. [CrossRef] [PubMed]

107. Tacx, J.C.J.F.; Schoffeleers, H.M.; Brands, A.G.M.; Teuwen, L. Dissolution behavior and solution properties of polyvinylalcohol as determined by viscometry and light scattering in DMSO, ethyleneglycol and water. Polymer 2000, 41, 947-957. [CrossRef]

108. Tang, X.; Alavi, S. Recent advances in starch, polyvinyl alcohol based polymer blends, nanocomposites and their biodegradability. Carbohydr. Polym. 2011, 85, 7-16. [CrossRef]

109. Wang, Y.; Zhang, W.; Li, J.; Fu, J. A novel LEuH/PVA luminescent hydrogel with ammonia response and self-recovery luminescence behavior. New J. Chem. 2019, 43, 5133-5138. [CrossRef]

110. Bhatt, R.; Bajpai, A.K. Solubility behavior of poly (diaminonaphthalene) doped poly (vinyl alcohol) films in different solvents and structural and electrical characterization of corresponding films. Mater. Res. Express 2019, 6, 105330. [CrossRef]

111. Jelinska, N.; Kalnins, M.; Tupureina, V.; Dzene, A. Poly (vinyl alcohol)/poly (vinyl acetate) blend films. Sci. J. Riga Tech. Univ. 2010, 21, 55-61.

112. Gholap, S.G.; Jog, J.P.; Badiger, M.V. Synthesis and characterization of hydrophobically modified poly(vinyl alcohol) hydrogel membrane. Polymer 2004, 45, 5863-5873. [CrossRef]

113. Nguyen, D.; Balsamo, V. Emulsification of heavy oil in aqueous solutions of poly(vinyl alcohol): A method for reducing apparent viscosity of production fluids. Energy and Fuels 2013, 27, 1736-1747. [CrossRef]

114. Raffa, P.; Broekhuis, A.A.; Picchioni, F. Polymeric surfactants for enhanced oil recovery: A review. J. Pet. Sci. Eng. 2016, 145, 723-733. [CrossRef]

115. Demerlis, C.C.; Schoneker, D.R. Review of the oral toxicity of polyvinyl alcohol (PVA). Food Chem. Toxicol. 2003, 41, 319-326. [CrossRef]

116. Alves, M.H.; Jensen, B.E.B.; Smith, A.A.A.; Zelikin, A.N. Poly(vinyl alcohol) physical hydrogels: New vista on a long serving biomaterial. Macromol. Biosci. 2011, 11, 1293-1313. [CrossRef]

117. Turk, C.T.S.; Oz, U.C.; Serim, T.M.; Hascicek, C. Formulation and optimization of nonionic surfactants emulsified nimesulideloaded PLGA-based nanoparticles by design of experiments. AAPS PharmSciTech 2014, 15, 161-176. [CrossRef] 
118. Rowe, R.C.; Sheskey, P.J.; Quinn, M.E. Handbook of Pharmaceutical Excipients; Libros Digitales-Pharmaceutical Press: London, UK, 2009; ISBN 9782705690229.

119. Gul, M.O.; Jones, S.A.; Dailey, L.A.; Nacer, H.; Ma, Y.; Sadouki, F.; Hider, R.; Araman, A.; Forbes, B. A poly(vinyl alcohol) nanoparticle platform for kinetic studies of inhaled particles. Inhal. Toxicol. 2009, 21, 631-640. [CrossRef]

120. Marin, E.; Rojas, J.; Ciro, Y. A review of polyvinyl alcohol derivatives: Promising materials for pharmaceutical and biomedical applications. Afr. J. Pharm. Pharmacol. 2014, 8, 674-684.

121. Rodríguez-Cruz, I.M.; Domínguez-Delgado, C.L.; Escobar-Chávez, J.J.; Leyva-Gómez, G.; Ganem-Quintanar, A.; QuintanarGuerrero, D. Nanoparticle infiltration to prepare solvent-free controlled drug delivery systems. Int. J. Pharm. 2009, 371, 177-181. [CrossRef]

122. Gebreel, R.M.; Edris, N.A.; Elmofty, H.M.; Tadros, M.I.; El-Nabarawi, M.A.; Hassan, D.H. Development and characterization of PLGA nanoparticle-laden hydrogels for sustained ocular delivery of norfloxacin in the treatment of pseudomonas keratitis: An experimental study. Drug Des. Devel. Ther. 2021, 15, 399-418. [CrossRef]

123. Qiu, S.; Ge, N.J.; Sun, D.K.; Zhao, S.; Sun, J.F.; Guo, Z.B.; Hu, K.; Gu, N. Synthesis and characterization of magnetic Polyvinyl Alcohol (PVA) hydrogel microspheres for the embolization of blood vessel. IEEE Trans. Biomed. Eng. 2016, 63, 730-736.

124. Covey, A.M.; Tuorto, S.; Brody, L.A.; Sofocleous, C.T.; Schubert, J.; von Tengg-Kobligk, H.; Getrajdman, G.I.; Schwartz, L.H.; Fong, Y.; Brown, K.T. Safety and efficacy of preoperative portal vein embolization with polyvinyl alcohol in 58 patients with liver metastases. Am. J. Roentgenol. 2005, 185, 1620-1626. [CrossRef]

125. Lang, R.A.; Grüntzig, P.M.; Weisgerber, C.; Weis, C.; Odermatt, E.K.; Kirschner, M.H. Polyvinyl alcohol gel prevents abdominal adhesion formation in a rabbit model. Fertil. Steril. 2007, 88, 1180-1186. [CrossRef]

126. Weis, C.; Odermatt, E.K.; Kressler, J.; Funke, Z.; Wehner, T.; Freytag, D. Poly(vinyl alcohol) membranes for adhesion prevention. J. Biomed. Mater. Res. 2004, 70, 191-202. [CrossRef]

127. Zhao, X.; Xiong, D.; Liu, Y. Improving surface wettability and lubrication of polyetheretherketone (PEEK) by combining with polyvinyl alcohol (PVA) hydrogel. J. Mech. Behav. Biomed. Mater. 2018, 82, 27-34. [CrossRef]

128. Zhang, J.; Lei, W.; Chen, J.; Liu, D.; Tang, B.; Li, J.; Wang, X. Enhancing the thermal and mechanical properties of polyvinyl alcohol (PVA) with boron nitride nanosheets and cellulose nanocrystals. Polymer 2018, 148, 101-108. [CrossRef]

129. Habiba, U.; Lee, J.J.L.; Joo, T.C.; Ang, B.C.; Afifi, A.M. Degradation of methyl orange and congo red by using chitosan/polyvinyl alcohol $/ \mathrm{TiO}_{2}$ electrospun nanofibrous membrane. Int. J. Biol. Macromol. 2019, 131, 821-827. [CrossRef]

130. Mahmoodi, N.M.; Mokhtari-Shourijeh, Z.; Abdi, J. Preparation of mesoporous polyvinyl alcohol/chitosan/silica composite nanofiber and dye removal from wastewater. Environ. Prog. Sustain. Energy 2019, 38, S100-S109. [CrossRef]

131. Karim, M.R.; Aijaz, M.O.; Alharth, N.H.; Alharbi, H.F.; Al-Mubaddel, F.S.; Awual, M.R. Composite nanofibers membranes of poly(vinyl alcohol)/chitosan for selective lead(II) and cadmium(II) ions removal from wastewater. Ecotoxicol. Environ. Saf. 2019, 169, 479-486. [CrossRef]

132. Do Nascimento, F.C.; de Aguiar, L.C.V.; Costa, L.A.T.; Fernandes, M.T.; Marassi, R.J.; de S. Gomes, A.; de Castro, J.A. Formulation and characterization of crosslinked polyvinyl alcohol (PVA) membranes: Effects of the crosslinking agents. Polym. Bull. 2021, 78, 917-929. [CrossRef]

133. Reddy, N.; Chen, L.; Zhang, Y.; Yang, Y. Reducing environmental pollution of the textile industry using keratin as alternative sizing agent to poly(vinyl alcohol). J. Clean. Prod. 2014, 65, 561-567. [CrossRef]

134. Kim, J.W.; Park, H.; Lee, G.; Jeong, Y.R.; Hong, S.Y.; Keum, K.; Yoon, J.; Kim, M.S.; Ha, J.S. Paper-like, thin, foldable, and self-healable electronics based on PVA/CNC nanocomposite film. Adv. Funct. Mater. 2019, 29, 1-14. [CrossRef]

135. Sajjan, A.M.; Naik, M.L.; Kulkarni, A.S.; Fazal-E-Habiba Rudgi, U.; M, A.; Shirnalli, G.G.; A, S.; Kalahal, P.B. Preparation and characterization of PVA-Ge/PEG-400 biodegradable plastic blend films for packaging applications. Chem. Data Collect. 2020, 26, 100338. [CrossRef]

136. Kaboorani, A.; Riedl, B. Effects of adding nano-clay on performance of polyvinyl acetate (PVA) as a wood adhesive. Compos. Part A Appl. Sci. Manuf. 2011, 42, 1031-1039. [CrossRef]

137. Abdulsalam, S. Production of emulsion house paint using polyvinyl acetate and gum arabic as binder. Int. J. Mater. Sci. Appl. 2015, 4, 350. [CrossRef]

138. Abdullah, Z.W.; Dong, Y.; Davies, I.J.; Barbhuiya, A. PVA, PVA blends and their nanocomposites for biodegradable packaging application. Polym. Plast. Technol. Eng. 2017, 56, 1307-1344. [CrossRef]

139. Hassan, C.M.; Peppas, N.A. Structure and applications of poly(vinyl alcohol) hydrogels produced by conventional crosslinking or by freezing/thawing methods. Adv. Polym. Sci. 2000, 153, 37-65.

140. Schubert, J.; Chanana, M. Coating matters: Review on colloidal stability of nanoparticles with biocompatible coatings in biological media, living cells and organisms. Curr. Med. Chem. 2018, 25, 4553-4586. [CrossRef] [PubMed]

141. Bolto, B.; Tran, T.; Hoang, M.; Xie, Z. Crosslinked poly(vinyl alcohol) membranes. Prog. Polym. Sci. 2009, 34, 969-981. [CrossRef]

142. Chen, K.; Chen, G.; Wei, S.; Yang, X.; Zhang, D.; Xu, L. Preparation and property of high strength and low friction PVA-HA/PAA composite hydrogel using annealing treatment. Mater. Sci. Eng. C 2018, 91, 579-588. [CrossRef]

143. Cieśla, K.; Abramowska, A. Effect of absorbed dose on starch:PVA films irradiated with gamma rays. Radiat. Phys. Chem. 2021, 180, 109290. [CrossRef]

144. Yu, C.; Li, B. Preparation and Characterization of carboxymethyl polyvinyl alcohol-graphite nanosheet composites. Polym. Compos. 2008, 29, 998-1005. [CrossRef] 
145. Zhao, X.; Zhang, Q.; Chen, D.; Lu, P. Enhanced mechanical properties of graphene-based polyvinyl alcohol composites. Macromolecules 2010, 43, 2357-2363. [CrossRef]

146. Gohil, J.M.; Bhattacharya, A.; Ray, P. Studies on the cross-linking of poly (vinyl alcohol). J. Polym. Res. 2006, 13, 161-169. [CrossRef]

147. Patel, A.R.; Vavia, P.R. Evaluation of synthesized cross linked polyvinyl alcohol as potential disintegrant. J. Pharm. Pharm. Sci. 2010, 13, 114-127. [CrossRef] [PubMed]

148. Mansur, H.S.; Sadahira, C.M.; Souza, A.N.; Mansur, A.A.P. FTIR spectroscopy characterization of poly (vinyl alcohol) hydrogel with different hydrolysis degree and chemically crosslinked with glutaraldehyde. Mater. Sci. Eng. C 2008, 28, 539-548. [CrossRef]

149. Yu, Q.; Song, Y.; Shi, X.; Xu, C.; Bin, Y. Preparation and properties of chitosan derivative/poly(vinyl alcohol) blend film crosslinked with glutaraldehyde. Carbohydr. Polym. 2011, 84, 465-470. [CrossRef]

150. Han, B.; Li, J.; Chen, C.; Xu, C.; Wickramasinghe, S.R. Effects of degree of formaldehyde acetal treatment and maleic acid crosslinking on solubility and diffusivity of water in PVA membranes. Chem. Eng. Res. Des. 2003, 81, 1385-1392. [CrossRef]

151. Riyajan, S.A.; Chaiponban, S.; Tanbumrung, K. Investigation of the preparation and physical properties of a novel semiinterpenetrating polymer network based on epoxised NR and PVA using maleic acid as the crosslinking agent. Chem. Eng. J. 2009, 153, 199-205. [CrossRef]

152. Tsai, C.E.; Lin, C.W.; Hwang, B.J. A novel crosslinking strategy for preparing poly(vinyl alcohol)-based proton-conducting membranes with high sulfonation. J. Power Sources 2010, 195, 2166-2173. [CrossRef]

153. Loughlin, R.G.; Tunney, M.M.; Donnelly, R.F.; Murphy, D.J.; Jenkins, M.; McCarron, P.A. Modulation of gel formation and drug-release characteristics of lidocaine-loaded poly(vinyl alcohol)-tetraborate hydrogel systems using scavenger polyol sugars. Eur. J. Pharm. Biopharm. 2008, 69, 1135-1146. [CrossRef] [PubMed]

154. Gulrez, S.K.H.; Al-Assaf, S.; Phillips, G.O. Hydrogels: Methods of preparation, characterization and applications. J. Vasc. Surg. 2010, 51, 1248-1259.

155. Alupei, I.C.; Popa, M.; Hamcerencu, M.; Abadie, M.J.M. Superabsorbant hydrogels based on xanthan and poly(vinyl alcohol): 1. The study of the swelling properties. Eur. Polym. J. 2002, 38, 2313-2320. [CrossRef]

156. Liong, M.; Shao, H.; Haun, J.B.; Lee, H.; Weissleder, R. Carboxymethylated polyvinyl alcohol stabilizes doped ferrofluids for biological applications. Adv. Mater. 2010, 22, 5168-5172. [CrossRef]

157. Drury, J.L.; Mooney, D.J. Hydrogels for tissue engineering: Scaffold design variables and applications. Biomaterials 2003, 24, 4337-4351. [CrossRef]

158. Sonker, A.K.; Rathore, K.; Nagarale, R.K.; Verma, V. Crosslinking of Polyvinyl Alcohol (PVA) and Effect of Crosslinker Shape (Aliphatic and Aromatic) Thereof. J. Polym. Environ. 2018, 26, 1782-1794. [CrossRef]

159. González-Guisasola, C.; Ribes-Greus, A. Dielectric relaxations and conductivity of cross-linked PVA/SSA/GO composite membranes for fuel cells. Polym. Test. 2018, 67, 55-67. [CrossRef]

160. El-Aziz, A.M.A.; El-Maghraby, A.; Taha, N.A. Comparison between polyvinyl alcohol (PVA) nanofiber and polyvinyl alcohol (PVA) nanofiber/hydroxyapatite (HA) for removal of Zn2+ ions from wastewater. Arab. J. Chem. 2017, 10, 1052-1060. [CrossRef]

161. Lu, Y.; Liu, X.; Luo, G. Synthesis of polystyrene latex via emulsion polymerization with poly(vinyl alcohol) as sole stabilizer. J. Appl. Polym. Sci. 2017, 134, 1-9. [CrossRef]

162. Siddharth, S.; Nayak, A.; Nayak, D.; Bindhani, B.K.; Kundu, C.N. Chitosan-Dextran sulfate coated doxorubicin loaded PLGAPVA-nanoparticles caused apoptosis in doxorubicin resistance breast cancer cells through induction of DNA damage. Sci. Rep. 2017, 7, 1-10. [CrossRef]

163. Liu, Z.; Jiang, M.; Kang, T.; Miao, D.; Gu, G.; Song, Q.; Yao, L.; Hu, Q.; Tu, Y.; Pang, Z.; et al. Lactoferrin-modified PEG-co-PCL nanoparticles for enhanced brain delivery of NAP peptide following intranasal administration. Biomaterials 2013, 34, 3870-3881. [CrossRef]

164. Mohammadi, G.; Mirzaeei, S.; Taghe, S.; Mohammadi, P. Preparation and Evaluation of Eudragit ${ }^{2}$ L100 Nanoparticles Loaded Impregnated with KT Tromethamine Loaded PVA -HEC Insertions for Ophthalmic Drug Delivery. Adv. Pharm. Bull. 2019, 9, 593-600. [CrossRef]

165. Suzuki, T.; Sasai, A.; Tsujimoto, H.; Yasunaga, T.; Ogawa, N.; Yamamoto, H. Promoting effect of type 17 collagen production by chlorogenic acid using PLGA nanoparticles in the human epidermal keratinocyte cell. J. Drug Deliv. Sci. Technol. 2020, 58, 101624. [CrossRef]

166. Fodor-Kardos, A.; Kiss, Á.; Monostroy, K.; Feczhó, T. Sustained in vitro interferon-beta release and in vivo toxicity of PLGA and PEG-PLGA nanoparticles. RSC Adv. 2020, 10, 15893-15900. [CrossRef]

167. Shahgordi, S.; Sankian, M.; Yazdani, Y.; Mashayekhi, K.; Hasan Ayati, S.; Sadeghi, M.; Saeidi, M.; Hashemi, M. Immune responses modulation by curcumin and allergen encapsulated into PLGA nanoparticles in mice model of rhinitis allergic through sublingual immunotherapy. Int. Immunopharmacol. 2020, 84, 106525. [CrossRef] [PubMed]

168. Sadozai, S.K.; Khan, S.A.; Karim, N.; Becker, D.; Steinbrück, N.; Gier, S.; Baseer, A.; Breinig, F.; Kickelbick, G.; Schneider, M. Ketoconazole-loaded PLGA nanoparticles and their synergism against Candida albicans when combined with silver nanoparticles. J. Drug Deliv. Sci. Technol. 2020, 56, 101574. [CrossRef]

169. Sousa, F.; Cruz, A.; Fonte, P.; Pinto, I.M.; Neves-Petersen, M.T.; Sarmento, B. A new paradigm for antiangiogenic therapy through controlled release of bevacizumab from PLGA nanoparticles. Sci. Rep. 2017, 7, 1-13. [CrossRef] 
170. Yenice Gürsu, B. Potential antibiofilm activity of farnesol-loaded poly(DL-lactide-co-glycolide) (PLGA) nanoparticles against Candida albicans. J. Anal. Sci. Technol. 2020, 11, 1-10. [CrossRef]

171. Ray, S.; Ghosh (Ray), S.; Mandal, S. Development of bicalutamide-loaded PLGA nanoparticles: Preparation, characterization and in-vitro evaluation for the treatment of prostate cancer. Artif. Cells Nanomed. Biotechnol. 2017, 45, 944-954. [CrossRef]

172. Behnke, M.; Vollrath, A.; Klepsch, L.; Beringer-siemers, B.; Stumpf, S. Optimized Encapsulation of the FLAP / PGES-1 Inhibitor BRP-187 in PVA-Stabilized PLGA Nnanoparticles using microfuidics. Polymers 2020, 12, 2751. [CrossRef]

173. Shin, N.; Shin, H.J.; Yi, Y.; Beom, J.; Lee, W.; Lee, C.H.; Kim, D.W. p66shc siRNA-encapsulated PLGA nanoparticles ameliorate neuropathic pain following spinal nerve ligation. Polymers 2020, 12, 1014. [CrossRef]

174. Takeuchi, I.; Kobayashi, S.; Hida, Y.; Makino, K. Estradiol-loaded PLGA nanoparticles for improving low bone mineral density of cancellous bone caused by osteoporosis: Application of enhanced charged nanoparticles with iontophoresis. Colloids Surf. B Biointerfaces 2017, 155, 35-40. [CrossRef]

175. Vibe, C.B.; Fenaroli, F.; Pires, D.; Wilson, S.R.; Bogoeva, V.; Kalluru, R.; Speth, M.; Anes, E.; Griffiths, G.; Hildahl, J. Thioridazine in PLGA nanoparticles reduces toxicity and improves rifampicin therapy against mycobacterial infection in zebrafish. Nanotoxicology 2016, 10, 680-688. [CrossRef] [PubMed]

176. Zaid, A.N.; Hassan, M.; Jaradat, N.; Assali, M.; Al-Abbassi, R.; Alkilany, A.; Abulateefeh, S.R. Formulation and characterization of combretastatin A4 loaded PLGA nanoparticles. IOP Sci. 2019, 6, 1250d7. [CrossRef]

177. Arzani, H.; Adabi, M.; Mosafer, J.; Dorkoosh, F.; Khosravani, M.; Maleki, H.; Nekounam, H.; Kamali, M. Preparation of curcuminloaded PLGA nanoparticles and investigation of its cytotoxicity effects on human glioblastoma U87MG cells. Biointerface Res. Appl. Chem. 2019, 9, 4225-4231.

178. Ni, J.; Liu, Y.; Hussain, T.; Li, M.; Liang, Z.; Liu, T.; Zhou, X. Recombinant ArgF PLGA nanoparticles enhances BCG induced immune responses against Mycobacterium bovis infection. Biomed. Pharmacother. 2021, 137, 111341. [CrossRef] [PubMed]

179. Nassir, A.M.; Shahzad, N.; Ibrahim, I.A.A.; Ahmad, I.; Md, S.; Ain, M.R. Resveratrol-loaded PLGA nanoparticles mediated programmed cell death in prostate cancer cells. Saudi Pharm. J. 2018, 26, 876-885. [CrossRef] [PubMed]

180. Prabhuraj, R.; Bomb, K.; Srivastava, R.; Bandyopadhyaya, R. Dual drug delivery of curcumin and niclosamide using PLGA nanoparticles for improved therapeutic effect on breast cancer cells. J. Polym. Res. 2020, 27, 1-13.

181. Anwer, M.K.; Mohammad, M.; Iqbal, M.; Ansari, M.N.; Ezzeldin, E.; Fatima, F.; Alshahrani, S.M.; Aldawsari, M.F.; Alalaiwe, A.; Alzahrani, A.A.; et al. Sustained release and enhanced oral bioavailability of rivaroxaban by PLGA nanoparticles with no food effect. J. Thromb. Thrombolysis 2020, 49, 404-412. [CrossRef]

182. Maksimenko, O.; Malinovskaya, J.; Shipulo, E.; Osipova, N.; Razzhivina, V.; Arantseva, D.; Yarovaya, O.; Mostovaya, U.; Khalansky, A.; Fedoseeva, V.; et al. Doxorubicin-loaded PLGA nanoparticles for the chemotherapy of glioblastoma: Towards the pharmaceutical development. Int. J. Pharm. 2019, 572, 118733. [CrossRef]

183. Si, S.; Li, H.; Han, X. Sustained release olmesartan medoxomil loaded PLGA nanoparticles with improved oral bioavailability to treat hypertension. J. Drug Deliv. Sci. Technol. 2020, 55, 101422. [CrossRef]

184. Madani, F.; Esnaashari, S.S.; Bergonzi, M.C.; Webster, T.J.; Younes, H.M.; Khosravani, M.; Adabi, M. Paclitaxel/methotrexate co-loaded PLGA nanoparticles in glioblastoma treatment: Formulation development and in vitro antitumor activity evaluation. Life Sci. 2020, 256, 117943. [CrossRef]

185. Tosyali, O.A.; Allahverdiyev, A.; Bagirova, M.; Abamor, E.S.; Aydogdu, M.; Dinparvar, S.; Acar, T.; Mustafaeva, Z.; Derman, S. Nano-co-delivery of lipophosphoglycan with soluble and autoclaved leishmania antigens into PLGA nanoparticles: Evaluation of in vitro and in vivo immunostimulatory effects against visceral leishmaniasis. Mater. Sci. Eng. C 2021, 120, 111684. [CrossRef] [PubMed]

186. Öztürk, A.A.; Namlı, İ.; Güleç, K.; Kıyan, H.T. Diclofenac sodium loaded PLGA nanoparticles for inflammatory diseases with high anti-inflammatory properties at low dose: Formulation, characterization and in vivo HET-CAM analysis. Microvasc. Res. 2020, 130, 103991. [CrossRef] [PubMed]

187. Kizilbey, K. Optimization of rutin-loaded PLGA nanoparticles synthesized by single-emulsion solvent evaporation method. ACS Omega 2019, 4, 555-562. [CrossRef]

188. Chung, K.; Ullah, I.; Kim, N.; Lim, J.; Shin, J.; Lee, S.C.; Jeon, S.; Kim, S.H.; Kumar, P.; Lee, S.K. Intranasal delivery of cancertargeting doxorubicin-loaded PLGA nanoparticles arrests glioblastoma growth. J. Drug Target. 2020, 28, 617-626. [CrossRef]

189. Rençber, S.; Aydın Köse, F.; Karavana, S.Y. Dexamethasone loaded PLGA nanoparticles for potential local treatment of oral precancerous lesions. Pharm. Dev. Technol. 2020, 25, 149-158. [CrossRef] [PubMed]

190. Ladnut, A.; Mamoon, K.; Thammasit, P.; Pawichai, S.; Tima, S.; Preechasuth, K.; Kaewkod, T.; Tragoolpua, Y.; Tragoolpua, K. In vitro antifungal and antivirulence activities of biologically synthesized ethanolic extract of propolis-loaded PLGA Nanoparticles against Candida albicans. Evid.-Based Complement. Altern. Med. 2019, 2019, 3715481.

191. Ahmad, N.; Ahmad, R.; Al Qatifi, S.; Alessa, M.; Al Hajji, H.; Sarafroz, M. A bioanalytical UHPLC based method used for the quantification of thymoquinone-loaded-PLGA-nanoparticles in the treatment of epilepsy. BMC Chem. 2020, 14, 10. [CrossRef]

192. Ali, H.; Weigmann, B.; Collnot, E.M.; Khan, S.A.; Windbergs, M.; Lehr, C.M. Budesonide loaded PLGA nanoparticles for targeting the inflamed intestinal mucosa-Pharmaceutical characterization and fluorescence imaging. Pharm. Res. 2016, 33, 1085-1092. [CrossRef] [PubMed] 
193. Almeida, K.B.; Ramos, A.S.; Nunes, J.B.B.; Silva, B.O.; Ferraz, E.R.A.; Fernandes, A.S.; Felzenszwalb, I.; Amaral, A.C.F.; Roullin, V.G.; Falcão, D.Q. PLGA nanoparticles optimized by Box-Behnken for efficient encapsulation of therapeutic Cymbopogon citratus essential oil. Colloids Surf. B Biointerfaces 2019, 181, 935-942. [CrossRef]

194. Anwer, M.K.; Al-Mansoor, M.A.; Jamil, S.; Al-Shdefat, R.; Ansari, M.N.; Shakeel, F. Development and evaluation of PLGA polymer based nanoparticles of quercetin. Int. J. Biol. Macromol. 2016, 92, 213-219. [CrossRef]

195. Attias Cohen, S.; Kingma, P.S.; Whitsett, J.A.; Goldbart, R.; Traitel, T.; Kost, J. SP-D loaded PLGA nanoparticles as drug delivery system for prevention and treatment of premature infant's lung diseases. Int. J. Pharm. 2020, 585, 119387. [CrossRef]

196. Baishya, R.; Nayak, D.K.; Kumar, D.; Sinha, S.; Gupta, A.; Ganguly, S.; Debnath, M.C. Ursolic acid loaded PLGA nanoparticles: In vitro and in vivo evaluation to explore tumor targeting ability on B16F10 melanoma cell lines. Pharm. Res. 2016, 33, 2691-2703. [CrossRef]

197. Haggag, Y.A.; Abosalha, A.K.; Tambuwala, M.M.; Osman, E.Y.; El-Gizawy, S.A.; Essa, E.A.; Donia, A.A. Polymeric nanoencapsulation of zaleplon into PLGA nanoparticles for enhanced pharmacokinetics and pharmacological activity. Biopharm. Drug Dispos. 2021, 42, 12-23. [CrossRef]

198. Arasoğlu, T.; Derman, S.; Mansuroğlu, B.; Uzunoğlu, D.; Koçyiğit, B.; Gümüş, B.; Acar, T.; Tuncer, B. Preparation, characterization, and enhanced antimicrobial activity: Quercetin-loaded PLGA nanoparticles against foodborne pathogens. Turk. J. Biol. 2017, 41, 127-140. [CrossRef]

199. Chaves, L.L.; Costa Lima, S.A.; Vieira, A.C.C.; Barreiros, L.; Segundo, M.A.; Ferreira, D.; Sarmento, B.; Reis, S. Development of PLGA nanoparticles loaded with clofazimine for oral delivery: Assessment of formulation variables and intestinal permeability. Eur. J. Pharm. Sci. 2018, 112, 28-37. [CrossRef]

200. Chen, X.T.; Wang, T. Preparation and characterization of atrazine-loaded biodegradable PLGA nanospheres. J. Integr. Agric. 2019, 18, 1035-1041. [CrossRef]

201. Chourasiya, V.; Bohrey, S.; Pandey, A. Formulation, optimization, characterization and in-vitro drug release kinetics of atenolol loaded PLGA nanoparticles using 33 factorial design for oral delivery. Mater. Discov. 2016, 5, 1-13. [CrossRef]

202. Fonte, P.; Lino, P.R.; Seabra, V.; Almeida, A.J.; Reis, S.; Sarmento, B. Annealing as a tool for the optimization of lyophilization and ensuring of the stability of protein-loaded PLGA nanoparticles. Int. J. Pharm. 2016, 503, 163-173. [CrossRef]

203. Jonderian, A.; Maalouf, R. Formulation and in vitro interaction of rhodamine-B loaded PLGA nanoparticles with cardiac myocytes. Front. Pharmacol. 2016, 7, 1-7. [CrossRef] [PubMed]

204. Colzani, B.; Pandolfi, L.; Hoti, A.; Iovene, P.A.; Natalello, A.; Avvakumova, S.; Colombo, M.; Prosperi, D. Investigation of antitumor activities of trastuzumab delivered by PLGA nanoparticles. Int. J. Nanomed. 2018, 13, 957-973. [CrossRef]

205. Anwer, M.K.; Mohammad, M.; Ezzeldin, E.; Fatima, F.; Alalaiwe, A.; Iqbal, M. Preparation of sustained release apremilast-loaded PLGAlga nanoparticles: In vitro characterization and in vivo pharmacokinetic study in rats. Int. J. Nanomed. 2019, 14, 1587-1595. [CrossRef]

206. Liang, Q.; Xiang, H.; Li, X.; Luo, C.; Ma, X.; Zhao, W.; Chen, J.; Tian, Z.; Li, X.; Song, X. Development of rifapentine-loaded PLGA-based nanoparticles: In vitro characterisation and in vivo study in mice. Int. J. Nanomed. 2020, 15, 7491-7507. [CrossRef]

207. Lin, W.; Li, C.; Xu, N.; Watanabe, M.; Xue, R.; Xu, A.; Araki, M.; Sun, R.; Liu, C.; Nasu, Y.; et al. Dual-functional PLGA nanoparticles co-loaded with indocyanine green and resiquimod for prostate cancer treatment. Int. J. Nanomed. 2021, 16, 2775-2787. [CrossRef]

208. Jeon, S.G.; Cha, M.Y.; Il Kim, J.; Hwang, T.W.; Kim, K.A.; Kim, T.H.; Song, K.C.; Kim, J.J.; Moon, M. Vitamin D-binding proteinloaded PLGA nanoparticles suppress Alzheimer's disease-related pathology in 5XFAD mice. Nanomed. Nanotechnol. Biol. Med. 2019, 17, 297-307. [CrossRef]

209. Malinovskaya, Y.; Melnikov, P.; Baklaushev, V.; Gabashvili, A.; Osipova, N.; Mantrov, S.; Ermolenko, Y.; Maksimenko, O.; Gorshkova, M.; Balabanyan, V.; et al. Delivery of doxorubicin-loaded PLGA nanoparticles into U87 human glioblastoma cells. Int. J. Pharm. 2017, 524, 77-90. [CrossRef] [PubMed]

210. Ribeiro, S.B.; de Araújo, A.A.; Oliveira, M.M.B.; dos Silva, A.M.; da Silva-Júnior, A.A.; Guerra, G.C.B.; de Brito, G.A.; de Leitão, R.F.; de Júnior, R.F.; Garcia, V.B.; et al. Effect of dexamethasone-loaded PLGA nanoparticles on oral mucositis induced by 5-fluorouracil. Pharmaceutics 2021, 13, 53. [CrossRef]

211. Sah, A.K.; Suresh, P.K.; Verma, V.K. PLGA nanoparticles for ocular delivery of loteprednol etabonate: A corneal penetration study. Artif. Cells Nanomed. Biotechnol. 2017, 45, 1156-1164. [CrossRef] [PubMed]

212. Babos, G.; Biró, E.; Meiczinger, M.; Feczkó, T. Dual drug delivery of sorafenib and doxorubicin from PLGA and PEG-PLGA polymeric nanoparticles. Polymers 2018, 10, 895. [CrossRef] [PubMed]

213. Silveira, N.; Longuinho, M.M.; Leitão, S.G.; Silva, R.S.F.; Lourenço, M.C.; Silva, P.E.A.; Pinto, M.D.C.F.R.; Abraçado, L.G.; Finotelli, P.V. Synthesis and characterization of the antitubercular phenazine lapazine and development of PLGA and PCL nanoparticles for its entrapment. Mater. Sci. Eng. C 2016, 58, 458-466. [CrossRef] [PubMed]

214. Abamor, E.S.; Tosyali, O.A.; Bagirova, M.; Allahverdiyev, A. Nigella sativa oil entrapped polycaprolactone nanoparticles for leishmaniasis treatment. IET Nanobiotechnology 2018, 12, 1018-1026. [CrossRef] [PubMed]

215. Alex, A.T.; Joseph, A.; Shavi, G.; Rao, J.V.; Udupa, N. Development and evaluation of carboplatin-loaded PCL nanoparticles for intranasal delivery. Drug Deliv. 2016, 23, 2144-2153. [CrossRef] [PubMed]

216. Öztürk, K.; Mashal, A.R.; Yegin, B.A.; Çalış, S. Preparation and in vitro evaluation of 5-fluorouracil-loaded PCL nanoparticles for colon cancer treatment. Pharm. Dev. Technol. 2017, 22, 635-641. [CrossRef] [PubMed] 
217. Grabowski, N.; Hillaireau, H.; Vergnaud, J.; Tsapis, N.; Pallardy, M.; Kerdine-Römer, S.; Fattal, E. Surface coating mediates the toxicity of polymeric nanoparticles towards human-like macrophages. Int. J. Pharm. 2015, 482, 75-83. [CrossRef] [PubMed]

218. Schlachet, I.; Halamish, H.M.; Sosnik, A. Mixed amphiphilic polymeric nanoparticles of chitosan, poly(vinyl alcohol) and poly(methyl methacrylate) for intranasal drug delivery: A preliminary in vivo study. Molecules 2020, 25, 4496. [CrossRef]

219. Jain, A.K.; Swarnakar, N.K.; Godugu, C.; Singh, R.P.; Jain, S. The effect of the oral administration of polymeric nanoparticles on the efficacy and toxicity of tamoxifen. Biomaterials 2011, 32, 503-515. [CrossRef]

220. Westedt, U.; Kalinowski, M.; Wittmar, M.; Merdan, T.; Unger, F.; Fuchs, J.; Schäller, S.; Bakowsky, U.; Kissel, T. Poly(vinyl alcohol)-graft-poly(lactide-co-glycolide) nanoparticles for local delivery of paclitaxel for restenosis treatment. J. Control. Release 2007, 119, 41-51. [CrossRef]

221. Nuttelman, C.R.; Mortisen, D.J.; Henry, S.M.; Anseth, K.S. Attachment of fibronectin to poly(vinyl alcohol) hydrogels promotes NIH3T3 cell adhesion, proliferation, and migration. J. Biomed. Mater. Res. 2001, 57, 217-223. [CrossRef]

222. Sahoo, S.K.; Panyam, J.; Prabha, S.; Labhasetwar, V. Residual polyvinyl alcohol associated with poly (D,L-lactide-co-glycolide) nanoparticles affects their physical properties and cellular uptake. J. Control. Release 2002, 82, 105-114. [CrossRef]

223. Zarrintaj, P.; Ramsey, J.D.; Samadi, A.; Atoufi, Z.; Yazdi, M.K.; Ganjali, M.R.; Amirabad, L.M.; Zangene, E.; Farokhi, M.; Formela, K.; et al. Poloxamer: A versatile tri-block copolymer for biomedical applications. Acta Biomater. 2020, 110, 37-67. [CrossRef] [PubMed]

224. Pitto-Barry, A.; Barry, N.P.E. Pluronic®block-copolymers in medicine: From chemical and biological versatility to rationalisation and clinical advances. Polym. Chem. 2014, 5, 3291-3297. [CrossRef]

225. Batrakova, E.V.; Kabanov, A.V. Pluronic block copolymers: Evolution of drug delivery concept from inert nanocarriers to biological response modifiers. J. Control. Release 2008, 130, 98-106. [CrossRef]

226. Werle, M. Natural and synthetic polymers as inhibitors of drug efflux pumps. Pharm. Res. 2008, 25, 500-511. [CrossRef]

227. Kabanov, A.V.; Batrakova, E.V.; Miller, D.W. Pluronic block copolymers as modulators of drug efflux transporter activity in the blood-brain barrier. Adv. Drug Deliv. Rev. 2003, 55, 151-164. [CrossRef]

228. Fischer, S.M.; Brandl, M.; Fricker, G. Effect of the non-ionic surfactant Poloxamer 188 on passive permeability of poorly soluble drugs across Caco-2 cell monolayers. Eur. J. Pharm. Biopharm. 2011, 79, 416-422. [CrossRef]

229. Zhang, Y.; Tang, L.; Sun, L.; Bao, J.; Song, C.; Huang, L.; Liu, K.; Tian, Y.; Tian, G.; Li, Z.; et al. A novel paclitaxel-loaded poly(epsilon-caprolactone)/Poloxamer 188 blend nanoparticle overcoming multidrug resistance for cancer treatment. Acta Biomater. 2010, 6, 2045-2052. [CrossRef] [PubMed]

230. Saxena, V.; Hussain, M.D. Poloxamer 407/TPGS mixed micelles for delivery of gambogic acid to breast and multidrug-resistant cancer. Int. J. Nanomed. 2012, 7, 713-721.

231. Peng, H.; Ali, A.; Lanan, M.; Hughes, E.; Wiltberger, K.; Guan, B.; Prajapati, S.; Hu, W. Mechanism investigation for poloxamer 188 raw material variation in cell culture. Biotechnol. Prog. 2016, 32, 767-775. [CrossRef] [PubMed]

232. Zarrintaj, P.; Ahmadi, Z.; Reza Saeb, M.; Mozafari, M. Poloxamer-based stimuli-responsive biomaterials. Mater. Today Proc. 2018, 5, 15516-15523. [CrossRef]

233. Wang, R.; Hughes, T.; Beck, S.; Vakil, S.; Li, S.; Pantano, P.; Draper, R.K. Generation of toxic degradation products by sonication of Pluronic ${ }^{\circledR}$ dispersants: Implications for nanotoxicity testing. Nanotoxicology 2013, 7, 1272-1281. [CrossRef]

234. Petri, B.; Bootz, A.; Khalansky, A.; Hekmatara, T.; Müller, R.; Uhl, R.; Kreuter, J.; Gelperina, S. Chemotherapy of brain tumour using doxorubicin bound to surfactant-coated poly(butyl cyanoacrylate) nanoparticles: Revisiting the role of surfactants. J. Control. Release 2007, 117, 51-58. [CrossRef] [PubMed]

235. Kabanov, A.V.; Batrakova, E.V.; Alakhov, V.Y. Pluronic®block copolymers for overcoming drug resistance in cancer. Adv. Drug Deliv. Rev. 2002, 54, 759-779. [CrossRef]

236. Gelperina, S.; Maksimenko, O.; Khalansky, A.; Vanchugova, L.; Shipulo, E.; Abbasova, K.; Berdiev, R.; Wohlfart, S.; Chepurnova, N.; Kreuter, J. Drug delivery to the brain using surfactant-coated poly(lactide-co-glycolide) nanoparticles: Influence of the formulation parameters. Eur. J. Pharm. Biopharm. 2010, 74, 157-163. [CrossRef] [PubMed]

237. Hosseinzadeh, H.; Atyabi, F.; Dinarvand, R.; Ostad, S.N. Chitosan-Pluronic nanoparticles as oral delivery of anticancer gemcitabine: Preparation and in vitro study. Int. J. Nanomed. 2012, 7, 1851-1863.

238. Pan, J.F.; Liu, N.H.; Sun, H.; Xu, F. Preparation and characterization of electrospun PLCL/ poloxamer nanofibers and Dextran/Gelatin Hydrogels for skin tissue engineering. PLoS ONE 2014, 9, e112885. [CrossRef] [PubMed]

239. Leyva-Gómez, G.; Santillan-Reyes, E.; Lima, E.; Madrid-Martínez, A.; Krötzsch, E.; Quintanar-Guerrero, D.; Garciadiego-Cázares, D.; Martínez-Jiménez, A.; Hernández Morales, M.; Ortega-Peña, S.; et al. A novel hydrogel of poloxamer 407 and chitosan obtained by gamma irradiation exhibits physicochemical properties for wound management. Mater. Sci. Eng. C 2017, 74, 36-46. [CrossRef]

240. Park, K.M.; Lee, S.Y.; Joung, Y.K.; Na, J.S.; Lee, M.C.; Park, K.D. Thermosensitive chitosan-Pluronic hydrogel as an injectable cell delivery carrier for cartilage regeneration. Acta Biomater. 2009, 5, 1956-1965. [CrossRef]

241. Qiu, Y.; Hamilton, S.K.; Temenoff, J. Improving mechanical properties of injectable polymers and composites. In Injectable Biomaterials; Brent, V., Ed.; Woodhead Publishing Series in Biomaterials; Woodhead Publishing: Sawston, Cambridge, UK, 2011; pp. 61-91. 
242. Gómez-Ballesteros, M.; Andrés-Guerrero, V.; Parra, F.J.; Marinich, J.; De-las-Heras, B.; Molina-Martínez, I.T.; Vázquez-Lasa, B.; Román, J.S.; Herrero-Vanrell, R. Amphiphilic acrylic nanoparticles containing the poloxamer star Bayfit ${ }^{\circledR} 10 \mathrm{WF} 15$ as ophthalmic drug carriers. Inject. Biomater. 2019, 11, 1213. [CrossRef]

243. Popescu, I.; Turtoi, M.; Suflet, D.M.; Dinu, M.V.; Darie-Nita, R.N.; Anghelache, M.; Calin, M.; Constantin, M. Alginate/poloxamer hydrogel obtained by thiol-acrylate photopolymerization for the alleviation of the inflammatory response of human keratinocytes. Int. J. Biol. Macromol. 2021, 180, 418-431. [CrossRef]

244. Del Prado-Audelo, M.L.; Magaña, J.J.; Mejía-Contreras, B.A.; Borbolla-Jiménez, F.V.; Giraldo-Gomez, D.M.; Piña-Barba, M.C.; Quintanar-Guerrero, D.; Leyva-Gómez, G. In vitro cell uptake evaluation of curcumin-loaded PCL/F68 nanoparticles for potential application in neuronal diseases. J. Drug Deliv. Sci. Technol. 2019, 52, 905-914. [CrossRef]

245. Del Prado Audelo, M.L.; Rodríguez Martínez, G.; Martínez López, V.; Carmina, O.S.; Velasquillo Martínez, C.; Magaña, J.;

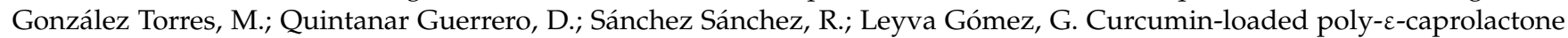
nanoparticles show antioxidant and cytoprotective effects in the presence of reactive oxygen species. J. Bioact. Compat. Polym. 2020, 35, 270-285.

246. Machado, M.E.; Furtado, P.D.S.; De Moraes, M.C.; Cláudio, L.; Pereira, R. Novel rivaroxaban — loaded poly (lactic-co-glycolic acid)/poloxamer nanoparticles: Preparation, physicochemical characterization, in vitro evaluation of time-dependent anticoagulant activity and toxicological profile. Nanotechnology 2021, 32, 135101. [CrossRef]

247. Saqib, M.; Shabbir Ali Bhatti, A.; Ahmad, N.M.; Ahmed, N.; Shahnaz, G.; Lebaz, N.; Elaissari, A. Amphotericin b loaded polymeric nanoparticles for treatment of leishmania infections. Nanomaterials 2020, 10, 1152. [CrossRef]

248. Moura, S.; Noro, J.; Cerqueira, P.; Silva, C.; Cavaco-Paulo, A.; Loureiro, A. Poloxamer 407 based-nanoparticles for controlled release of methotrexate. Int. J. Pharm. 2020, 575, 118924. [CrossRef] [PubMed]

249. Loureiro, A.; Noro, J.; Abreu, A.S.; Nogueira, E.; Soares Da Costa, D.; Silva, C.; Cavaco-Paulo, A. Absence of Albumin Improves in Vitro Cellular Uptake and Disruption of Poloxamer 407-Based Nanoparticles inside Cancer Cells. Mol. Pharm. 2018, 15, 527-535. [CrossRef] [PubMed]

250. Le, T.M.P.; Pham, V.P.; Dang, T.M.L.; La, T.H.; Le, T.H.; Le, Q.H. Preparation of curcumin-loaded pluronic F127/chitosan nanoparticles for cancer therapy. Adv. Nat. Sci. Nanosci. Nanotechnol. 2013, 4, 025001.

251. Allotey-Babington, G.L.; Nettey, H.; D’Sa, S.; Braz Gomes, K.; D'Souza, M.J. Cancer chemotherapy: Effect of poloxamer modified nanoparticles on cellular function. J. Drug Deliv. Sci. Technol. 2018, 47, 181-192. [CrossRef]

252. Yan, F.; Zhang, C.; Zheng, Y.; Mei, L.; Tang, L.; Song, C.; Sun, H.; Huang, L. The effect of poloxamer 188 on nanoparticle morphology, size, cancer cell uptake, and cytotoxicity. Nanomed. Nanotechnol. Biol. Med. 2010, 6, 170-178. [CrossRef]

253. Jain, D.; Athawale, R.; Bajaj, A.; Shrikhande, S.; Goel, P.N.; Gude, R.P. Studies on stabilization mechanism and stealth effect of poloxamer 188 onto PLGA nanoparticles. Colloids Surf. B Biointerfaces 2013, 109, 59-67. [CrossRef]

254. Mei, L.; Zhang, Y.; Zheng, Y.; Tian, G.; Song, C.; Yang, D.; Chen, H.; Sun, H.; Tian, Y.; Liu, K.; et al. A novel docetaxel-loaded poly ( $\varepsilon$-caprolactone)/Pluronic F68 nanoparticle overcoming multidrug resistance for breast cancer treatment. Nanoscale Res. Lett. 2009, 4, 1530-1539. [CrossRef]

255. Beck-broichsitter, M.; Bohr, A.; Ruge, C.A. Poloxamer-decorated polymer nanoparticles for lung surfactant compatibility Poloxamer-decorated polymer nanoparticles for lung surfactant compatibility. Mol. Pharm. 2017, 14, 3464-3472. [CrossRef]

256. Scheeren, L.E.; Nogueira, D.R.; Macedo, L.B.; Vinardell, M.P.; Infante, M.R.; Rolim, C.M.B. PEGylated and poloxamer-modified chitosan nanoparticles incorporating a lysine-based surfactant for $\mathrm{pH}$-triggered doxorubicin release. Colloids Surf. B Biointerfaces 2016, 138, 117-127. [CrossRef]

257. Mandal, B.B.; Kundu, S.C. Self-assembled silk sericin/poloxamer nanoparticles as nanocarriers of hydrophobic and hydrophilic drugs for targeted delivery. Nanotechnology 2009, 20, 355101. [CrossRef] [PubMed]

258. Gupta, P.N.; Jain, S.; Nehate, C.; Alam, N.; Khare, V.; Dhar, R.; Saneja, A.; Kour, S.; Singh, S.K. Development and evaluation of paclitaxel loaded PLGA:poloxamer blend nanoparticles for cancer chemotherapy. Int. J. Biol. Macromol. 2014, 69, 393-399. [CrossRef] [PubMed]

259. Mayol, L.; Serri, C.; Menale, C.; Crispi, S.; Teresa, M.; Mita, L.; Giarra, S.; Forte, M.; Saija, A.; Biondi, M.; et al. Curcumin loaded PLGA - poloxamer blend nanoparticles induce cell cycle arrest in mesothelioma cells. Eur. J. Pharm. Biopharm. 2015, 93, 37-45. [CrossRef] [PubMed]

260. Cosco, D.; Cilurzo, F.; Maiuolo, J.; Federico, C.; Di Martino, M.T.; Cristiano, M.C.; Tassone, P.; Fresta, M.; Paolino, D. Delivery of miR-34a by chitosan/PLGA nanoplexes for the anticancer treatment of multiple myeloma. Sci. Rep. 2015, 5, 17579. [CrossRef] [PubMed]

261. Lombardo, G.E.; Maggisano, V.; Celano, M.; Cosco, D.; Mignogna, C.; Baldan, F.; Lepore, S.M.; Allegri, L.; Moretti, S.; Durante, C.; et al. Anti-htert sirna-loaded nanoparticles block the growth of anaplastic thyroid cancer xenograft. Mol. Cancer Ther. 2018, 17, 1187-1195. [CrossRef] [PubMed]

262. Aljaeid, B.M.; El-Say, K.M.; Hosny, K.M. Chitosan-TPP nanoparticles stabilized by poloxamer for controlling the release and enhancing the bioavailability of doxazosin mesylate: In vitro, and in vivo evaluation. Drug Dev. Ind. Pharm. 2019, 45, 1130-1139. [CrossRef] [PubMed]

263. Pereverzeva, E.; Treschalin, I.; Treschalin, M.; Arantseva, D.; Ermolenko, Y.; Kumskova, N.; Maksimenko, O.; Balabanyan, V.; Kreuter, J.; Gelperina, S. Toxicological study of doxorubicin-loaded PLGA nanoparticles for the treatment of glioblastoma. Int. J. Pharm. 2019, 554, 161-178. [CrossRef] 
264. Zhang, X.; Sun, M.; Zheng, A.; Cao, D.; Bi, Y.; Sun, J. Preparation and characterization of insulin-loaded bioadhesive PLGA nanoparticles for oral administration. Eur. J. Pharm. Sci. 2012, 45, 632-638. [CrossRef]

265. Zhu, B.; Zhang, H.; Yu, L. Novel transferrin modified and doxorubicin loaded Pluronic 85/lipid-polymeric nanoparticles for the treatment of leukemia: In vitro and in vivo therapeutic effect evaluation. Biomed. Pharmacother. 2017, 86, 547-554. [CrossRef]

266. Tang, X.; Liang, Y.; Feng, X.; Zhang, R.; Jin, X.; Sun, L. Co-delivery of docetaxel and Poloxamer 235 by PLGA-TPGS nanoparticles for breast cancer treatment. Mater. Sci. Eng. C 2015, 49, 348-355. [CrossRef] [PubMed]

267. Lin, Y.H.; Lin, J.H.; Hong, Y.S. Development of chitosan/poly- $\gamma$-glutamic acid/pluronic/curcumin nanoparticles in chitosan dressings for wound regeneration. J. Biomed. Mater. Res. 2017, 105, 81-90. [CrossRef]

268. Kalita, S.; Devi, B.; Kandimalla, R.; Sharma, K.K.; Sharma, A.; Kalita, K.; Kataki, A.C.; Kotoky, J. Chloramphenicol encapsulated in

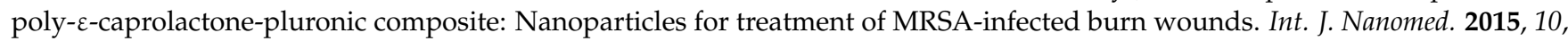
2971-2984.

269. Luo, Y.Y.; Xiong, X.Y.; Cheng, F.; Gong, Y.C.; Li, Z.L.; Li, Y.P. The targeting properties of folate-conjugated Pluronic F127/poly (lactic-co-glycolic) nanoparticles. Int. J. Biol. Macromol. 2017, 105, 711-719. [CrossRef]

270. Niu, J.; Yuan, M.; Chen, C.; Wang, L.; Tang, Z.; Fan, Y.; Liu, X.; Ma, Y.J.; Gan, Y. Berberine-loaded thiolated pluronic f127 polymeric micelles for improving skin permeation and retention. Int. J. Nanomed. 2020, 15, 9987-10005. [CrossRef]

271. Gyulai, G.; Magyar, A.; Rohonczy, J.; Orosz, J.; Yamasaki, M.; Bősze, S. Kiss Preparation and characterization of cationic pluronic for surface modification and functionalization of polymeric drug delivery nanoparticles. Express Polym. Lett. 2016, 10, 216-226. [CrossRef]

272. Wang, Y.; Wang, Y.; Wang, J.; Lei, W.; Li, K.; Wu, D.; Wang, X. Pharmacokinetics, biodistribution, and bioavailability of gossypol-loaded Pluronic®F127 nanoparticles. J. Drug Deliv. Sci. Technol. 2018, 45, 388-396. [CrossRef]

273. Li, S.; Xiong, Y.; Zhang, X. Poloxamer surface modified trimethyl chitosan nanoparticles for the effective delivery of methotrexate in osteosarcoma. Biomed. Pharmacother. 2017, 90, 872-879. [CrossRef] [PubMed]

274. Redhead, H.M.; Davis, S.S.; Illum, L. Drug delivery in poly (lactide-co-glycolide) nanoparticles surface modified with poloxamer 407 and poloxamine 908: In vitro characterisation and in vivo evaluation. J. Control. Release 2001, 70, 353-363. [CrossRef]

275. Angelo, I.; Garcia-fuentes, M.; Parajo, Y.; Welle, A. Nanoparticles Based on PLGA: Poloxamer Blends for the Delivery of Proangiogenic Growth Factors. Mol. Pharm. 2010, 260, 25-33.

276. Leyva-Gómez, G.; González-Trujano, M.E.; López-Ruiz, E.; Couraud, P.-O.; Wekslerg, B.; Romero, I.; Miller, F.; Delie, F.; Allémann, E.; Quintanar-Guerrero, D. Nanoparticle formulation improves the anticonvulsant effect of clonazepam on the pentylenetetrazoleinduced seizures: Behavior and electroencephalogram. J. Pharm. Sci. 2014, 103, 2509-2519. [CrossRef]

277. Li, Y.; Sun, L.; Yao, L.; Xiong, X.; Li, Z. Acute and subacute toxicity studies of Pluronic P85 / poly (lactic acid ) nanoparticles in mice. Micro Nano Lett. 2013, 8, 796-800. [CrossRef]

278. Fullagar, B.; Rao, W.; Gilor, C.; Xu, F.; He, X.; Adin, C.A. Nano-Encapsulation of Bilirubin in Pluronic F127-Chitosan Improves Uptake in b Cells and Increases Islet Viability and Function after Hypoxic Stress. Cell Transplant. 2017, 26, 1703-1715. [CrossRef]

279. Tao, Y.; Han, J.; Wang, X.; Dou, H. Biointerfaces Nano-formulation of paclitaxel by vitamin E succinate functionalized pluronic micelles for enhanced encapsulation, stability and cytotoxicity. Colloids Surf. B Biointerfaces 2013, 102, 604-610. [CrossRef]

280. Bruschi, M.L.; Borghi-pangoni, F.B.; Junqueira, M.V.; Ferreira, S.B.D.S. Nanostructured therapeutic systems with bioadhesive and thermoresponsive properties. In Nanostructures for Novel Therapy; Fica, D., Grumezescu, A., Eds.; Elsevier Inc.: Amsterdam, The Netherlands, 2017; pp. 313-342.

281. Russo, E.; Villa, C. Poloxamer Hydrogels for Biomedical Applications. Pharmaceutics 2019, 11, 671. [CrossRef]

282. Grindel, J.M.; Jaworski, T.; Piraner, O.; Emanuele, R.M.; Balasubramanian, M. Distribution, metabolism, and excretion of a novel surface-active agent, purified poloxamer 188, in rats, dogs, and humans. J. Pharm. Sci. 2002, 91, 1936-1947. [CrossRef]

283. d'Avanzo, N.; Celia, C.; Barone, A.; Carafa, M.; Di Marzio, L.; Santos, H.A.; Fresta, M. Immunogenicity of Polyethylene Glycol Based Nanomedicines: Mechanisms, Clinical Implications and Systematic Approach. Adv. Ther. 2020, 3, 1900170. [CrossRef]

284. Jarak, I.; Varela, C.L.; Tavares da Silva, E.; Roleira, F.F.M.; Veiga, F.; Figueiras, A. Pluronic-based nanovehicles: Recent advances in anticancer therapeutic applications. Eur. J. Med. Chem. 2020, 206, 112526. [CrossRef] [PubMed]

285. Chanan-Khan, A.; Szebeni, J.; Savay, S.; Liebes, L.; Rafique, N.M.; Alving, C.R.; Muggia, F.M. Complement activation following first exposure to pegylated liposomal doxorubicin (Doxil): Possible role in hypersensitivity reactions. Ann. Oncol. Off. J. Eur. Soc. Med. Oncol. 2003, 14, 1430-1437. [CrossRef] [PubMed]

286. Escalona-Rayo, O.; Fuentes-Vázquez, P.; Leyva-Gómez, G.; Cisneros, B.; Villalobos, R.; Magaña, J.J.; Quintanar-Guerrero, D. Nanoparticulate strategies for the treatment of polyglutamine diseases by halting the protein aggregation process. Drug Dev. Ind. Pharm. 2017, 43, 871-888. [CrossRef] [PubMed]

287. Wang, Y.; Pi, C.; Feng, X.; Hou, Y.; Zhao, L.; Wei, Y. The influence of nanoparticle properties on oral bioavailability of drugs. Int. J. Nanomed. 2020, 15, 6295-6310. [CrossRef]

288. Li, Y.; Li, J.; Zhang, X.; Ding, J.; Mao, S. Non-ionic surfactants as novel intranasal absorption enhancers: In vitro and in vivo characterization. Drug Deliv. 2016, 23, 2272-2279. [CrossRef]

289. Morales, J.O.; Peters, J.I.; Williams, R.O. Surfactants: Their critical role in enhancing drug delivery to the lungs. Ther. Deliv. 2011, 2, 623-641. [CrossRef]

290. ICH Expert Working Group. Pharmaceutical Development Q8(R2); ICH: Geneva, Switzerland, 2009; pp. 1-24. 
291. Beg, S.; Rahman, M.; Kohli, K. Quality-by-design approach as a systematic tool for the development of nanopharmaceutical products. Drug Discov. Today 2019, 24, 717-725. [CrossRef]

292. Zhang, L.; Mao, S. Application of quality by design in the current drug development. Asian J. Pharm. Sci. 2017, 12, 1-8. [CrossRef]

293. Li, J.; Qiao, Y.; Wu, Z. Nanosystem trends in drug delivery using quality-by-design concept. J. Control. Release 2017, 256, 9-18. [CrossRef]

294. Yerlikaya, F.; Ozgen, A.; Vural, I.; Guven, O.; Karaagaoglu, E.; Khan, M.A.; Capan, Y. Development and Evaluation of Paclitaxel Nanoparticles Using a Quality-by-Design Approach. J. Pharm. Sci. 2013, 102, 3748-3761. [CrossRef] [PubMed]

295. Soni, G.; Kale, K.; Shetty, S.; Gupta, M.K.; Yadav, K.S. Quality by design (QbD) approach in processing polymeric nanoparticles loading anticancer drugs by high pressure homogenizer. Heliyon 2020, 6, e03846. [CrossRef] [PubMed]

296. Saha, M.; Saha, D.R.; Ulhosna, T.; Sharker, S.M.; Shohag, M.H.; Islam, M.S.; Ray, S.K.; Rahman, G.S.; Reza, H.M. QbD based development of resveratrol-loaded mucoadhesive lecithin/chitosan nanoparticles for prolonged ocular drug delivery. J. Drug Deliv. Sci. Technol. 2021, 63, 102480. [CrossRef]

297. Patel, D.; Patel, M.; Soni, T.; Suhagia, B. Topical arginine solid lipid nanoparticles: Development and characterization by QbD approach. J. Drug Deliv. Sci. Technol. 2021, 61, 102329. [CrossRef]

298. Cunha, S.; Costa, C.P.; Moreira, J.N.; Sousa Lobo, J.M.; Silva, A.C. Using the quality by design (QbD) approach to optimize formulations of lipid nanoparticles and nanoemulsions: A review. Nanomed. Nanotechnol. Biol. Med. 2020, 28, 102206. [CrossRef]

299. Rapalli, V.K.; Banerjee, S.; Khan, S.; Jha, P.N.; Gupta, G.; Dua, K.; Hasnain, M.S.; Nayak, A.K.; Dubey, S.K.; Singhvi, G. QbD-driven formulation development and evaluation of topical hydrogel containing ketoconazole loaded cubosomes. Mater. Sci. Eng. C 2021, 119, 111548. [CrossRef]

300. Shekhawat, P.; Pokharkar, V. Risk assessment and QbD based optimization of an Eprosartan mesylate nanosuspension: In-vitro characterization, PAMPA and in-vivo assessment. Int. J. Pharm. 2019, 567, 118415. [CrossRef]

301. Beg, S.; Saini, S.; Bandopadhyay, S.; Katare, O.P.; Singh, B. QbD-driven development and evaluation of nanostructured lipid carriers (NLCs) of Olmesartan medoxomil employing multivariate statistical techniques. Drug Dev. Ind. Pharm. 2018, 44, 407-420. [CrossRef] [PubMed]

302. Mahmood, A.; Rapalli, V.K.; Waghule, T.; Gorantla, S.; Singhvi, G. Luliconazole loaded lyotropic liquid crystalline nanoparticles for topical delivery: QbD driven optimization, in-vitro characterization and dermatokinetic assessment. Chem. Phys. Lipids 2021, 234, 105028. [CrossRef] 